\title{
Estudios
}

\section{SOBRe el PARlamento}

Manuel

Aragón Reyes

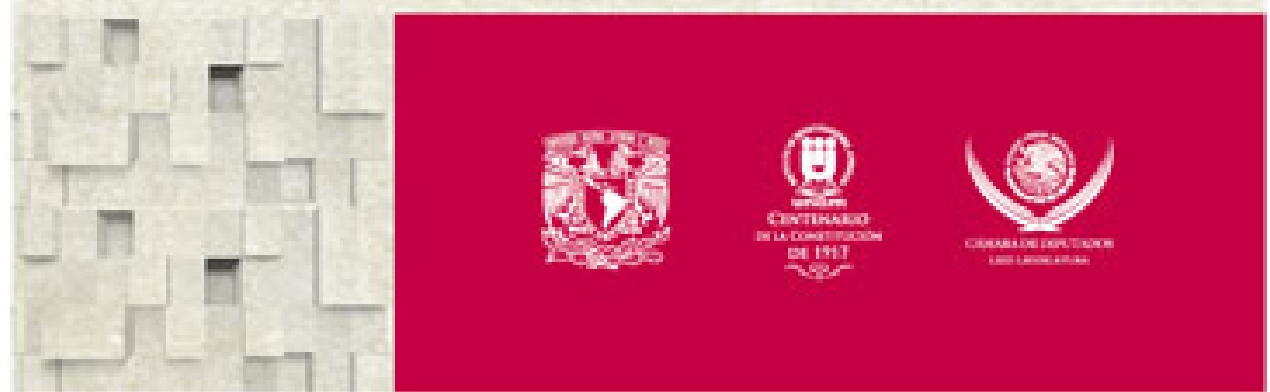


ESTUDIOS SOBRE EL PARLAMENTO 
INSTITUTO DE INVESTIGACIONES JURÍDICAS

Serie Estudios JuRídicos, núm. 309

\title{
GOORDINACIÓN EDITORIAL
}

\author{
Lic. Raúl Márquez Romero \\ Secretario Técnico
}

Lic. Wendy Vanesa Rocha Cacho

Jefa del Departamento de Publicaciones

Vanessa Díaz

Cuidado de la edición

Ricardo Hernández Montes de Oca

Apoyo editorial

Javier Mendoza Villegas

Formación en computadora

Edith Aguilar Gálvez

Elaboración de portada 


\title{
MANUEL ARAGÓN REYES
}

\section{ESTUDIOS \\ SOBRE EL PARLAMENTO}

\author{
Prólogo \\ Cecilia Mora-Donatto
}
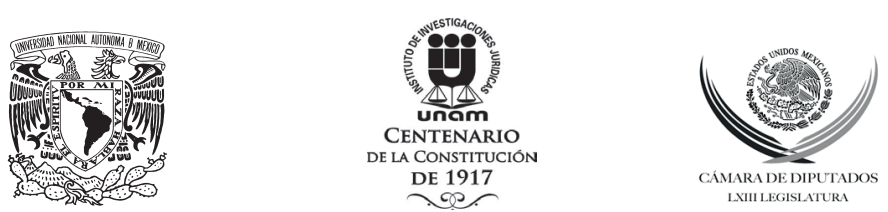

UNIVERSIDAD NACIONAL AUTÓNOMA DE MÉXICO INSTITUTO DE INVESTIGACIONES JURÍDICAS CÁMARA DE DIPUTADOS. LXIII LEGISLATURA MÉXICO, 2017 
Primera edición: 22 de septiembre de 2017

DR (C) 2017. Universidad Nacional Autónoma de México

\section{INSTITUTO DE INVESTIGACIONESJURÍDICAS}

Circuito Maestro Mario de la Cueva s/n

Ciudad de la Investigación en Humanidades

Ciudad Universitaria, 04510 Ciudad de México

Impreso y hecho en México

ISBN 978-607-02-9240-8 


\section{CONTENIDO}

Prólogo . . . . . . . . . . . . .

Cecilia MORA-DONATTO

CAPÍTULO PRIMERO

PARLAMENTARISMO Y ANTIPARLAMENTARISMO (ESTUDIO PRELIMINAR A LA OBRA SOBRE EL PARLAMENTARISMO, DE GARL SCHMITT)

I. Leer, hoy, a Carl Schmitt . . . . . . . . . . . . . 1

II. Parlamentarismo y antiparlamentarismo en el periodo de entreguerras. La Alemania de Weimar........ 5

III. La crítica schmittiana a la democracia parlamentaria.

IV. Carl Schmitt entre el pasado y el presente. La situación actual del parlamentarismo.............. 20

Capítulo SEgundo

SISTEMA PARLAMENTARIO, SISTEMA

PRESIDENGIALISTA Y DINÁMICA ENTRE LOS PODERES DEL ESTADO. ANÁLISIS COMPARADO

I. Objetivo. . . . . . . . . . . . . . 27

II. Democracia y control del poder . . . . . . . . . 27 
III. Parlamentarismo y presidencialismo, hoy . . . . . . . .

IV. La necesidad de "parlamentarizar" el régimen parlamentario ....................... 36

V. El significado actual del control parlamentario. El control parlamentario en sentido amplio. "Competencias" de control y "derechos" de control . . . . . . . . . . .

VI. La relación actual entre los poderes del Estado. Poderes políticos y poder jurisdiccional. . . . . . . . . . . 44

\section{CAPÍtulo TerCERO}

\section{FUENTES DEL DERECHO PARLAMENTARIO}

I. Sobre el concepto de derecho parlamentario . . . . . .

II. La diversidad de fuentes del derecho parlamentario . .

CAPÍtulo GUARTO

\section{LA FUNGIÓN LEGISLATIVA DE LOS PARLAMENTOS Y SUS PROBLEMAS ACTUALES}

I. Sobre las dificultades de dotar de significado a la fun-

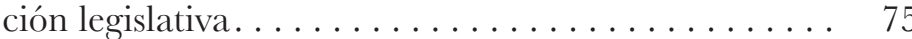

II. Diversidad de tipos de leyes y heterogeneidad normativa de sus contenidos . . . . . . . . . . . . . . . 82

III. Ley, Parlamento, procedimiento legislativo y principio democrático ........................ 85

IV. Consideraciones sobre el procedimiento legislativo. . . 89

V. Acerca de algunas propuestas de reforma . . . . . . . . 93 


\section{CAPÍTUlO QUINTO \\ LA INICIATIVA LEGISLATIVA}

I. Aclaración preliminar . . . . . . . . . . . . . . . 103

II. El significado general de la iniciativa legislativa . . . . 104

III. La iniciativa legislativa en el derecho español. Antecedentes históricos y características del sistema adoptado por la Constitución . . . . . . . . . . . . . . . . . 108

IV. Las modalidades de la iniciativa legislativa . . . . . . 111

V. Conclusiones . . . . . . . . . . . . . . . . . . . 132

Gapítulo SEXTO

SOBRE EL SIGNIFICADO ACTUAL DEL PARLAMENTO Y DEL CONTROL PARLAMENTARIO: INFORMACIÓN PARLAMENTARIA Y FUNCIÓN DE CONTROL

I. Introducción . . . . . . . . . . . . . . . . . . . . 135

II. Algunas consideraciones críticas sobre la práctica de nuestra forma parlamentaria de gobierno....... . 137

III. La tentación presidencialista de nuestro parlamentarismo . . . . . . . . . . . . . . . . . . . . . . 142

IV. La función del gobierno y la función del Parlamento. Los rasgos esenciales de nuestra forma de gobierno . . 144

V. El significado actual del control parlamentario . . . . . 147

VI. Algunas propuestas de reforma . . . . . . . . . . 152 


\section{PRÓLOGO}

La obra jurídica del doctor Manuel Aragón es ampliamente conocida y reconocida en toda Iberoamérica. Sus trabajos sobre justicia constitucional en los que, desde luego, ha hecho notables contribuciones son multicitados y de referencia obligada en España y en algunos países de América; cuenta, además, con discípulos y discípulas que son o han sido jueces constitucionales, o bien, letrados o letradas del Tribunal Constitucional Español. Pero tengo la impresión de que sus investigaciones sobre el Parlamento no han sido suficientemente difundidas en México en donde, todavía, sigue existiendo un déficit muy grande de calificada y buena bibliografía, desde la perspectiva jurídica, sobre el tema - situación que no ha ocurrido en otros países del entorno, como Argentina o Colombia; ahí, la obra de Aragón ha sido muy difundida - Por esta razón en mi calidad de coordinadora de la Colección Temas de Democracia y Parlamento me siento muy complacida de que el doctor Aragón haya accedido a que la colección albergue en este número a una serie de artículos, ya clásicos, que ha escrito magistralmente en torno a los problemas y retos actuales del Parlamento.

La situación en México del Congreso federal y de las asambleas estatales en un momento tan crucial como es la posibilidad de la reelección consecutiva de diputados y senadores, impone a la academia el compromiso de suministrar elementos que permitan una amplia y seria reflexión sobre el papel del Parlamento en los Estados democráticos. El Congreso de la Unión sigue teniendo una deuda con la sociedad mexicana por no haber consensado, todavía, una reforma de amplio calado que lo actualice en sus normas internas y transparentes en el ejercicio de sus re- 
Este libro forma parte del acervo de la Biblioteca Jurídica Virtual del Instituto de Investigaciones Jurídicas de la UNAM

cursos; en suma, lo acerque más a las demandas ciudadanas que a los intereses de grupos o de partidos. Repensar al Congreso en el contexto por el que atraviesa nuestro país es obligado y hacerlo, precisamente, con quienes hoy tienen la honrosa responsabilidad de ejercer la representación es un espacio inmejorable y una magnífica oportunidad para que los diputados mexicanos que no conocen la obra de Aragón, la conozcan y quienes ya la conocen, la reconozcan.

El presente libro está dividido en seis capítulos que se corresponden con igual número de ensayos. El primero recoge el "Estudio preliminar a la obra de Carl Schmitt Sobre el parlamentarismo", en el que Aragón, partiendo de la contextualización temporal de la obra, desarrolla un análisis riguroso de la misma y examina detalladamente las impugnaciones que Schmitt emprende contra la democracia parlamentaria que lo llevan a afirmar que en realidad lo que perseguía dicho autor con sus críticas no era su mejoramiento sino su destrucción; pero al tiempo que va adentrándose al pensamiento schmittiano va construyendo - con apoyo en el pensamiento de Kelsen - una muy estructurada y vigorosa defensa de la democracia parlamentaria como forma de Estado. La lectura de este ensayo es, hoy, muy pertinente no sólo por la defensa que entraña en favor de la democracia y la libertad, sino porque proporciona además elementos muy convenientes para hacer frente a los nuevos racismos y nacionalismos a los que se enfrentan las sociedades en pleno siglo XXI.

En el segundo capítulo intitulado "Sistema parlamentario, sistema presidencial y dinámica entre los poderes del Estado. Análisis comparado", el autor aborda un tema tan antiguo como actual: la división de poderes, pero no cualquier distribución del poder, sino aquella que tiene como objetivo garantizar la libertad de los ciudadanos. Para ello, el constitucionalista español divide este capítulo en cinco apartados, a saber: el primero lo dedica a la relación entre la democracia y el control de los poderes públicos; el segundo lo destina a establecer las diferencias que actualmente existen entre parlamentarismo y presidencialismo; el tercero está 
Este libro forma parte del acervo de la Biblioteca Jurídica Virtual del Instituto de Investigaciones Jurídicas de la UNAM

dedicado al rol que cumple el Parlamento en la actualidad; en el cuarto hace un extraordinario análisis del significado del control parlamentario como elemento fundamental de la forma de Estado democrático-parlamentaria, y el quinto es para mostrar la relación actual entre los poderes públicos. En suma, el capítulo ofrece una serie de reflexiones interesantes en torno a los sistemas presidencial y parlamentario, analizándolos y confrontándolos, al destacar las relaciones y equilibrios entre los poderes en uno y otro sistema.

El tercer capítulo está dedicado a un tema poco explorado en la doctrina mexicana, como es el de "Las fuentes del derecho parlamentario"; el rigor académico al que nos tiene acostumbrados el profesor Aragón servirá, sin duda, no sólo para entender las grandes transformaciones que dicho derecho ha experimentado a lo largo del siglo XX, sino también para ubicar la posición de los reglamentos parlamentarios en la escala de fuentes, así como para entender el papel fundamental de las normas (Constitución y reglamento) que rigen las competencias y el actuar del Parlamento y el estatuto de sus miembros. Por otro lado, nos ayudará también a comprender la exigencia que recae sobre el Parlamento de respetar, en el ejercicio de sus funciones y procedimientos, invariablemente dichas normas (fuentes).

En un Estado constitucional y democrático el Parlamento es el órgano encargado de la creación del derecho y como tal debe estar sujeto al mismo, así como ajustar el ejercicio de sus competencias a las normas que lo rigen. Como afirma el autor: las normas principales del derecho parlamentario se han constitucionalizado no sólo porque se contengan (con amplitud) en la Constitución sino, sobre todo, porque tales normas constitucionales son jurisdiccionalmente aplicables. Esta es la gran diferencia respecto de aquellos países en los que la Constitución sigue siendo una norma política; tales afirmaciones son una llamada de atención, en nuestro entorno, a la Corte y al Congreso mexicanos para profundizar en la idea de que el Congreso también está limitado por la Constitución y sus normas sujetas al control 
Este libro forma parte del acervo de la Biblioteca Jurídica Virtual del Instituto de Investigaciones Jurídicas de la UNAM

de constitucionalidad que, en todo Estado de derecho, ejerce el Tribunal Constitucional, en nuestro caso, la Suprema Corte de Justicia de la Nación. Como puede observarse, se trata de un capítulo que merece una lectura cuidadosa y detenida porque aborda temas que pueden generar reflexiones particulares con relación a temas concretos de nuestras asambleas representativas, ya sea la federal o las locales.

En el cuarto capítulo se aborda con toda su relevancia una de las funciones clásicas del Parlamento que llevó a llamarlo, justamente, Poder Legislativo; su título es "La función legislativa de los Parlamentos y sus problemas actuales". En este apartado el autor no sólo enfrenta el problema teórico de qué debe entenderse hoy por función legislativa, sino, al mismo tiempo, analiza las categorías y tipos de las leyes. Con base en esas consideraciones aborda un tema fundamental de la democracia representativa, como es la relación entre Parlamento, ley, procedimiento legislativo y principio democrático. Pero, como es su costumbre, Aragón trasciende del análisis para concluir el capítulo con una serie de propuestas de reforma que tienen como finalidad fortalecer y agilizar esta función frente a la enorme capacidad "legisladora" de los gobiernos; propone, entre otras cosas, potenciar al máximo posible la actividad legisladora del Parlamento de tal manera que pueda aprobar "buenas" leyes a través del acortamiento de plazos, leyes de lectura única, limitación de enmiendas, etcétera, de tal manera que sea posible la aprobación del mayor número de leyes en el menor lapso posible; al tiempo que se reduzca drásticamente la delegación legislativa a favor del gobierno.

En esta misma lógica de comprender en toda su magnitud la función legislativa de los Parlamentos en los Estados contemporáneos, el capítulo quinto está dedicado justamente a "La iniciativa legislativa", a la que el autor dedica una serie de reflexiones a sus características generales para así poder emprender algunos de los problemas que se plantean en las diversas modalidades a través de las cuales la iniciativa se ejerce. Advierte que en el análisis del tema se distancia de la doctrina dominante que entiende que la 
Este libro forma parte del acervo de la Biblioteca Jurídica Virtual del Instituto de Investigaciones Jurídicas de la UNAM

propuesta y la iniciativa son lo mismo; revisa detenidamente la iniciativa gubernamental, parlamentaria y la popular.

Para Aragón es importante entender las implicaciones de los tipos de iniciativas, ya que éstas son el acto mediante el cual se pone en marcha obligatoriamente el procedimiento legislativo, esto es: el acto mediante el cual se abre paso a la fase de deliberación y enmienda; por ello cabe distinguirla de la simple propuesta legislativa. Algunas de sus reflexiones tienen perfecta vigencia para el caso mexicano, como es la necesidad de regular, al interior del gobierno, la iniciativa del presidente de la República. Ya han existido esfuerzos para establecer procedimientos para tal efecto, como fue en 2003 el Acuerdo por el que se Emiten los Lineamientos para la Elaboración, Revisión y Seguimiento de Iniciativas de Leyes y Decretos del Ejecutivo Federal pero que, en virtud de la alternancia en la Presidencia de la República, no quedó claro si ese Acuerdo sigue aplicándose, fue sustituido por otro similar o bien dejó de aplicarse. Otro tema interesante es el de la iniciativa popular cuyas reflexiones nos pueden servir para entender una figura novedosa en nuestro derecho.

El capítulo sexto se dedica a un tema fascinante que, en pluma del doctor Aragón, es una delicia leerlo. Bajo el título "Sobre el significado actual del Parlamento y del control parlamentario: información parlamentaria y función de control", el autor aborda la cuestión del control del poder, tema central del Estado democrático, y en ese contexto le otorga al Parlamento un papel protagónico. Si como ha afirmado Aragón sin control judicial no hay Estado de derecho, sin control político no hay Estado democrático y éste descansa no sólo en la división de poderes, sino también en el equilibrio entre ellos, esto es, en la existencia de una extensa red de controles que impide el ejercicio ilimitado e irresponsable del poder. El control parlamentario es uno de esos controles, de carácter político, cuyo agente es el Parlamento y su objeto es la acción del gobierno, pero estamos frente a una facultad que es necesario que las asambleas representativas ejerzan, practiquen, ejecuten y lo hagan con protagonismo, ya que 
Este libro forma parte del acervo de la Biblioteca Jurídica Virtual del Instituto de Investigaciones Jurídicas de la UNAM

su ausencia genera un vacío en la vida democrática de cualquier país. Experiencias de corrupción muy recientes en México de algunos gobernadores, incluso en estados de la República con una amplia población en pobreza extrema, ponen en evidencia que la inacción de este tipo de control (entre otras razones) permitió un ejercicio desmedido, irracional e incontrolable del poder de los ejecutivos locales que han dejado las arcas del erario público severamente comprometidas. Las conclusiones, con aplicación a nuestra realidad, que pueden extraerse de este capítulo son muchas y muy bastas, sugiero una lectura minuciosa del mismo con la mirada puesta en nuestros problemas que muchas veces se escalan frente a la ausencia de congresos fuertes, respetados y dispuestos a ejercer con decisión y determinación sus competencias.

En el apartado dedicado al control parlamentario y la democracia de partidos, el autor pone en su justa dimensión la importancia y el rol de los partidos políticos, entendiéndolos como instrumentos, valiosos, de la democracia; pero sólo eso, sin perder de vista que el "pueblo es la única fuente de poder". Más aún, sostiene que tampoco los partidos agotan los cauces de expresión del pluralismo social que se manifiesta también a través de los sindicatos, las asociaciones y demás formaciones colectivas que integran la diversidad de creencias e intereses que existen en una comunidad; destaca al parecer un mal común, de nuestros días, como es el que representa que los partidos políticos quieran adentrarse en el seno de organizaciones e instituciones para controlarlas, influenciarlas o dirigirlas, generando el fenómeno de la denostada "politización"; mejor sería llamarla "partidización", una situación también muy extendida en nuestro país.

Como puede intuir el lector, el presente es un libro de obligada lectura para quienes tengan como objeto de estudio al Parlamento, se desarrollen como representantes, o bien, les interese el futuro del sistema democrático y del poder que representa a los ciudadanos. A mi juicio, constituye un conjunto de páginas brillantemente escritas en las que el autor refleja su pensamiento liberal y democrático; ofrece una serie de reflexiones y propues- 
Este libro forma parte del acervo de la Biblioteca Jurídica Virtual del Instituto de Investigaciones Jurídicas de la UNAM

tas que pueden y deben contribuir al perfeccionamiento de las facultades del Parlamento en un Estado constitucional y democrático. No debo extenderme en estas líneas cuyo único objetivo es presentar la obra del profesor Aragón, pero no quiero dejar de mencionar que nuevamente he disfrutado enormemente la relectura de sus escritos, para la elaboración de este prólogo, y cada vez que regreso a estos les descubro nuevas e innovadoras ideas.

En un mes de junio de hace diecinueve años mi primer libro, Las comisiones parlamentarias de investigación como órganos de control político, se veía ampliamente favorecido con el prólogo del doctor Manuel Aragón; mi maestro, en ese momento estaba culminando mis estudios de doctorado bajo su magistral dirección; desde esa época me une a él además de un profundo respeto y un cariño entrañable coincidencias científicas e inquietudes intelectuales, que se forjaron en el seno de una relación académica muy estrecha entre nuestro Instituto, del cual es investigador honorario, y la Universidad Autónoma de Madrid. Por todo ello, es para mí un motivo de enorme satisfacción personal presentar ahora, en México, este libro de su autoría que estoy segura generará amplias reflexiones y comentarios positivos en beneficio de nuestra vida parlamentaria.

El doctor Aragón, además de ser un destacado constitucionalista, es un Maestro, así con mayúscula; quienes a lo largo de su amplia trayectoria académica en distintos espacios y momentos han tenido la oportunidad de ser sus discípulos, coincidirán conmigo en que es un verdadero privilegio pertenecer a su escuela, de la que un pilar fundamental era nuestro también muy querido maestro don Francisco Rubio Llorente, ausente desde 2016, en nuestras reflexiones académicas pero presente en nuestros pensamientos y sentimientos más afectuosos. Hoy el profesor Aragón es catedrático emérito de la Universidad Autónoma de Madrid y continúa iluminando las reflexiones y discusiones jurídicas en el Seminario de Profesores de Derecho Constitucional de nuestra escuela; su pensamiento analítico sigue siendo referencia y su voz autorizada y escuchada en momentos de incertidumbre jurídica 
Este libro forma parte del acervo de la Biblioteca Jurídica Virtual del Instituto de Investigaciones Jurídicas de la UNAM

en España, estoy segura de que continuará vigente por muchos años haciendo aportaciones y provocando reflexiones en el pensamiento jurídico actual del entorno iberoamericano.

Quiero terminar estas líneas dejando testimonio de mi gratitud personal e institucional al doctor Manuel Aragón Reyes por aceptar con agrado esta publicación cuyos principales beneficiarios serán los diputados de la LXIII Legislatura de la Cámara de Diputados del H. Congreso de la Unión y hago votos por que los frutos sean abundantes, estoy segura que así será. Deseo además convertir esta publicación en un homenaje al pensamiento y la obra del doctor Aragón y a los valores que él representa: la generosidad personal y la entrega dedicada a toda una vida académica y universitaria ejemplar, como diríamos coloquial, pero afectuosamente, los "pumas": ¡cómo no lo vamos a querer!

\section{Cecilia MORA-DONATTO}

Coordinadora de la colección Temas de Democracia y Parlamento 
Este libro forma parte del acervo de la Biblioteca Jurídica Virtual del Instituto de Investigaciones Jurídicas de la UNAM

CAPÍTULO PRIMERO

\section{PARLAMENTARISMO Y ANTIPARLAMENTARISMO (ESTUDIO PRELIMINAR A LA OBRA SOBRE EL PARLAMENTARISMO, DE CARL SCHMITT)}

\section{LEER, HOY, A CARL SCHMITT}

Escribir a estas alturas unas páginas introductorias para la edición española del estudio de Carl Schmitt sobre el parlamentarismo ${ }^{1}$

1 Die Geistesgeschichtliche Lage des heutigen Parlamentarismus se publicó en 1923. En la 2a. ed., de 1926, Carl Schmitt incluyó el Prefacio sobre las contradicciones entre parlamentarismo y democracia, réplica a la crítica efectuada por Richard Thoma. La traducción literal al español del título de la obra podría ser La situación histórico-intelectual del parlamentarismo en nuestros días (o La situación histórico-espiritual del parlamentarismo contemporáneo, como aparece en el libro de Estévez Araujo, J. A., La crisis del Estado de derecho liberal. Schmitt en Weimar, Barcelona, 1989, p. 208; o La situación histórico-espiritual del actual parlamentarismo, como figura en el Prólogo de Pedro de Vega a la reedición española, Madrid, 1983, del libro de Schmitt La defensa de la Constitución, p. 12). Los traductores de la presente edición han optado, pues, por la fidelidad literal en el título: Situación histórico-intelectual del parlamentarismo de hoy, sin perjuicio de que el libro que ahora se publica (como comprende algo más que este ensayo) lleve por título global Sobre el parlamentarismo. Ellen Kennedy, en su traducción al inglés de esta obra (Cambridge, Massachusetts, 1988), ha preferido emplear como título The Crisis of Parliamentary Democracy, dando cuenta de ello en una modélica nota "sobre el texto y la traducción" (pp. IX-XI). Jean-Louis Schlegel, traductor de la edición francesa (París, 1988), ha optado por una versión aún más sintética (y menos descriptiva): Parlementarisme et démocratie, sin ofrecer explicación alguna. No debo extenderme en más detalles relativos a las características de la versión española de esta obra o a su comparación con otras versiones extranjeras, puesto que mi responsabilidad en la presente edición de Tecnos se reduce estrictamente a la elaboración de estas líneas introductorias y no he participado, pues, ni en la "edición" (en el sentido anglosajón del término), 
Este libro forma parte del acervo de la Biblioteca Jurídica Virtual del Instituto de Investigaciones Jurídicas de la UNAM

supone, cuanto menos, admitir la oportunidad de esa edición. Adelanto que la oportunidad me parece mayor en lo que esta obra tiene de testimonio del pasado (la época que transcurre entre las dos guerras mundiales) que en lo que pueda tener de valor para el presente. Sirve mejor para comprender "aquella" crisis del parlamentarismo que para entender los problemas del parlamentarismo de hoy. Sin embargo, y aunque prevalezca, a mi juicio, el valor histórico del texto sobre su posible significado actual, ello no quiere decir que carezca por completo de este último. El ensayo de Schmitt conserva aún buena parte de su capacidad revulsiva precisamente porque algunos de los problemas que trata siguen vigentes. De todos modos, ni siquiera habría que dar estas explicaciones. Basta con decir que es una obra del más controvertido de los grandes autores de la teoría del Estado de este siglo. Con ello sobraría para dar por buena la oportunidad de la edición, que viene así a añadir un nuevo e importante título al caudal, ya crecido, de los textos de Carl Schmitt traducidos al español. ${ }^{2}$

El lector tiene en sus manos una ocasión de sustraerse a la frivolidad. Schmitt nunca fue un "intelectual piadoso" y, por ello mismo, con igual falta de "piedad" hay que acercarse a sus escritos; sin ninguna ingenuidad, pero sin caer tampoco en el prejuicio, poniendo, en fin, especial cuidado en no incurrir en las confusiones que propician los textos de quien fue, sobre todo, un implacable sofista.

ni en la traducción, ni en la decisión de incluir, como apéndice, el escrito de Schmitt sobre la disolución del Reichstag en 1924.

2 Der Hüter der Verfassung, de 1931, se tradujo, en ese mismo año, con el título La defensa de la Constitución; Verfassunslehre, de 1928, se tradujo (Teoría de la Constitución) en 1934; Der Begriff des Politischen, de 1928, se tradujo (El concepto de la política) en 1941; Die Diktatur, de 1921, se tradujo (La dictadura) en 1968; Legalität und Legitimität, de 1932, se tradujo (Legalidad y legitimidad) en 1971. Ésta es sólo una muestra, ya que, aparte de las obras citadas (quizá las más importantes de las vertidas al español), se ha traducido en nuestro país una treintena más de monografías y artículos de revista. Véanse los datos en Gómez Orfanell, G., Excepción y normalidad en el pensamiento de Carl Schmitt, Madrid, 1986, pp. 15-18. En ese libro puede encontrarse también (pp. 12-28) un buen examen de "la recepción del pensamiento de Schmitt en España". 
Este libro forma parte del acervo de la Biblioteca Jurídica Virtual del Instituto de Investigaciones Jurídicas de la UNAM

Pasquale Pasquino, en el Prefacio a la edición francesa de esta obra, ${ }^{3}$ después de recordar que Rudolf Smend, en 1928 (en su Verfassung und Verfassungsrecht), había definido el debate suscitado por el texto de Schmitt sobre el parlamentarismo como una de las "discusiones más importantes y más instructivas de los últimos años concerniente a la teoría del Estado", añade que "sesenta años después, las tesis defendidas por el más controvertido de los teóricos de la política de nuestro siglo, no han perdido su fuerza analítica y continúan representando un desafío para el pensamiento liberal y democrático".

Este párrafo resulta muy ilustrativo de lo que constituye, a mi entender, una defectuosa comprensión de la obra de Schmitt. Es cierto, como decía Smend, que en los años veinte la carga polémica de aquella obra fue formidable. No lo es tanto, en cambio, que en nuestros días pueda desempeñar el mismo papel. La importancia que entonces alcanzó hay que explicarla, más que por la contundencia argumental del autor, por las tensiones político-intelectuales de aquella época y, más específicamente aún, por la situación de crisis permanente en que vivió la República de Weimar. Ni el mundo espiritual de entonces puede compararse con el de ahora, ni los problemas que afligían a la democracia en aquellos años son exactamente iguales a los que la amenazan en el presente.

Y, desde luego, esa amenaza o esos peligros eran por aquel tiempo mucho más intensos de lo que hoy pueden ser. Algunos de los problemas señalados por Schmitt persisten, no cabe negarlo, pero muchos otros sólo eran hijos de aquellas conflictivas circunstancias.

Pero no se trata únicamente de que haya cambiado el escenario, es que no todas las ideas de Schmitt sobre el parlamentarismo y la democracia poseen la suficiente "fuerza analítica" para seguir representado hoy un "desafio" al "pensamiento liberal y democrático". Algunas de esas ideas lo que sí tienen es una gran fuerza retórica, capaz de dar apariencia analítica a

\section{Parlementarisme et démocratie, cit., p. 7.}


Este libro forma parte del acervo de la Biblioteca Jurídica Virtual del Instituto de Investigaciones Jurídicas de la UNAM

unos juicios sustentados, de verdad, en proposiciones dogmáticas, cuando no en sofismas. El pensamiento de Carl Schmitt no era, prevalentemente, analítico; era, sobre todo, teológico.

Pasemos a otra cita. José A. Estévez Araujo, en su excelente libro sobre Schmitt, ${ }^{4}$ se propone "llamar la atención acerca de lo que podrían denominarse «trampas ideológicas» que se ocultan tras los planteamientos schmittianos. Con ello se intenta evitar que se lleve a cabo una utilización ingenua de las categorías de Schmitt, como si éstas fueran absolutamente inocentes". 5 "Hay - dirá - que aproximarse a Schmitt, pues, con precaución. Sólo se acercan sin reservas a este autor quienes propugnan una salida autoritaria a la actual crisis o quienes inocentemente confian en la «fecundidad» de Schmitt sin darse cuenta de la carga ideológica que su pensamiento contiene". ${ }^{6}$

Ahora bien, estos mismos párrafos parecen caer (o al menos propiciar la caída) en otra "trampa ideológica" de la que conviene salir. Que no hay que ser ingenuos con Schmitt, por supuesto. Que Schmitt, con su crítica a la democracia parlamentaria, no perseguía su mejoramiento sino su destrucción, de acuerdo, y es algo que conviene resaltar. Que esa "intención” invalide, por sí sola, la crítica schmittiana, es cosa bien distinta. La falta de rigor de unas ideas no deriva de sus "malas intenciones", sino de su mal planteamiento. Denunciar que "el rey está desnudo", si verdaderamente lo está, no deja de ser un juicio riguroso, aunque la denuncia se haga no para vestirlo, sino para destronarlo.

Ni toda la crítica schmittiana a la democracia parlamentaria es "rigurosa", ni toda ella es enteramente "falaz". Distinguir lo que hay de rigor y de falacia en Schmitt (y lo que de efímero y permanente hay en aquella crítica) me parece que es el único modo serio de acometer el estudio de su pensamiento.

4 La crisis del Estado de derecho liberal. Schmitt en Weimar, cit. Se trata, sin duda, de uno de los mejores trabajos sobre Carl Schmitt realizados en España.

5 Ibidem, p. 9.

6 Ibidem, p. 261. 
Este libro forma parte del acervo de la Biblioteca Jurídica Virtual del Instituto de Investigaciones Jurídicas de la UNAM

\section{PARLAMENTARISMO Y ANTIPARLAMENTARISMO \\ EN EL PERIODO DE ENTREGUERRAS. \\ LA ALEMANIA DE WEIMAR}

La República alemana surgida con el desenlace de la guerra europea y regulada por la Constitución de Weimar fue, sin lugar a dudas, el escenario en que de manera más completa se expresó, a lo largo de los años veinte y treinta, la polémica parlamentarismo-antiparlamentarismo, discusión que se producía también en otros países europeos, pero en ninguno con tanta intensidad teórica como allí.

No eran la crisis económica o la sensación de humillación por las imposiciones del Tratado de Versalles las únicas causas que originarían en la Alemania de Weimar una situación política inestable y una pugna de partidos y de ideas en la que se enfrentarían, radicalmente, el autoritarismo y la democracia. Ocurre que allí se daban, además, otras condiciones que convertirían a la joven República en un lugar propicio para que se desarrollara, con virulencia, la llamada crisis del liberalismo o, más exactamente, del Estado liberal de derecho. Esa crisis alcanzará en Alemania una especial intensidad porque a las circunstancias muy singulares antes aludidas (y a las circunstancias más generales que afectaban a todos los países europeos, y que, por conocidas, no hace falta señalar aquí), se añadirían otras condiciones, también específicamente alemanas: una firme tradición política de Estado escasamente democrático (asentado en el principio monárquico, en el primado de la burocracia y en el papel relevante del ejército) y una tradición intelectual donde el peso del liberalismo era muy liviano en comparación con la fuerza, notable, de las corrientes antiliberales (idealismo, conservadurismo, irracionalismo, anarquismo y marxismo). No es de extrañar el cúmulo de dificultades que allí encontraría de inmediato, el nuevo Estado democráticoliberal establecido por la Constitución de 1919. En pocos lugares, pues, como en Alemania, la crisis de ese Estado se iba a producir con tanta intensidad y en pocos lugares también, como allí, iba a ser objeto de tan intenso debate intelectual. 
Este libro forma parte del acervo de la Biblioteca Jurídica Virtual del Instituto de Investigaciones Jurídicas de la UNAM

La democracia parlamentaria sería atacada, desde la izquierda, por el anarquismo y el marxismo; desde la derecha, por el conservadurismo reaccionario. No hace falta extenderse aquí sobre la crítica anarquista, ni tampoco sobre la marxista, pese a que ésta desempeñó un importante papel en aquel periodo. ${ }^{7}$ A los efectos que ahora importan, la crítica que cabe tener en cuenta es la que entonces se hizo al parlamentarismo desde la derecha (o, más exactamente desde el pensamiento reaccionario), ya que, si hubiera que definir a esa crítica por medio de un autor, el nombre no podría ser otro que el de Carl Schmitt. Y ese fue, por lo demás, y como bien se sabe, el ataque que allí, a la postre (en las manos del nacionalsocialismo), resultó mortal, al menos hasta 1945.

\section{LA CRÍTICA SCHMITTIANA A LA DEMOCRACIA PARLAMENTARIA ${ }^{8}$}

\section{Crítica al parlamentarismo como forma de gobierno}

La crítica de Carl Schmitt al parlamentarismo puede descomponerse en dos estratos: la crítica al parlamentarismo como forma de

7 Un buen ejemplo de la polémica dentro del socialismo austríaco (y, por extensión, alemán) entre los partidarios de la democracia parlamentaria y los partidarios de la revolución y la dictadura del proletariado, puede encontrarse en el debate entre Otto Bauer y Max Adler, bien estudiado por Gurland, A. en Marxismus und Diktatur, Leipzig, Alemania, 1930. Un aceptable resumen, aunque algo sesgado ideológicamente, es el que hace de esa polémica Roberto Racinaro en su estudio "Hans Kelsen y el debate sobre democracia y parlamentarismo en los años veinte y treinta", que está publicado como introducción a la edición española, México, 1982, de la obra de Kelsen Socialismo y Estado.

8 Esta crítica no se contiene sólo en su estudio sobre el parlamentarismo (que es objeto de la presente edición), aunque ahí se revelen ya los argumentos principales; se manifestará también, con más o menos intensidad, en la mayor parte de las demás obras de Schmitt y, muy especialmente en la Teoría de la Constitución y en Legalidad y legitimidad. En ese sentido, la exposición que sigue de la doctrina schmittiana utiliza como fuente el conjunto de su obra. Así se obtiene una imagen más completa de las ideas de Schmitt sobre el parlamentarismo de la que resultaría si sólo se tuviese en cuenta su aludido estudio de 1923-1926. 
Este libro forma parte del acervo de la Biblioteca Jurídica Virtual del Instituto de Investigaciones Jurídicas de la UNAM

gobierno y la crítica al parlamentarismo como forma de Estado. Por lo que se refiere al primer supuesto, se achacará al parlamentarismo la inestabilidad de los gobiernos y el excesivo dominio de éstos por el Parlamento; se dirá, así, que el parlamentarismo conduce o al gobierno ejercido por el propio Parlamento o a la imposibilidad misma de gobernar, resultados ambos, se concluirá, que no sólo son contradictorios con la división de poderes (que el parlamentarismo, como régimen liberal, por principio habría de respetar), sino que también son inconciliables con las necesidades del Estado "administrativo" ("eficaz") de nuestro tiempo.

Este nivel de crítica será muy efectivo en aquellos años, aunque adolece de una patente debilidad teórica en cuanto que identifica el parlamentarismo con la situación específica de éste (en la III República francesa o en la República alemana de Weimar) en un concreto periodo histórico, olvidando otras épocas y otros ejemplos, y atribuyendo así a ese régimen unas características que no son exactamente consecuencias del mismo, sino de su corrupción en algún momento o lugar determinados. Esto es, a través de la operación intelectual, tan schmittiana, de la conversión de lo excepcional en normal, se definen como defectos teóricos del modelo (el parlamentarismo) los que sólo derivan de un ejemplo práctico de su mal funcionamiento. No es de extrañar que, en una crítica así, desaparezca cualquier planteamiento reformista destinado a corregir los defectos de la práctica sin abjurar por entero del modelo (por ejemplo, las propuestas de modificaciones electorales e institucionales tendentes a un nuevo "parlamentarismo racionalizado", que tuvieron su expositor más conocido en Mirkine-Guetzevitch).

El régimen parlamentario ha muerto, vendría a sostener Schmitt, porque genera gobiernos inestables; pero, en el caso hipotético de que tal inestabilidad no se produzca, también el régimen habría muerto porque existiría entonces un régimen de asamblea, es decir, un gobierno del Parlamento y no del Ejecutivo; no obstante, si por la disciplina de partido esa estabilidad significase, en verdad, el predominio, contrario, del gobierno sobre el Parlamen- 
Este libro forma parte del acervo de la Biblioteca Jurídica Virtual del Instituto de Investigaciones Jurídicas de la UNAM

to, también habría muerto el régimen porque no sería ya "parlamentario", sino "gubernativo". Como se ve, Schmitt no parece dejar salida alguna al parlamentarismo.

Ahora bien, los sofismas, por muy inteligentemente que se construyan, tienen siempre unos límites. Schmitt es consciente (aunque no lo confiese) de las debilidades de su crítica en este plano (es decir, de su crítica reducida a descalificar el parlamentarismo como forma de gobierno). El parlamentarismo no siempre ha generado inestabilidad gubernamental. La estabilidad del Poder Ejecutivo no implica, por principio, un régimen de asamblea; el predominio del gobierno no tiene por qué conducir, inexorablemente, a una inoperancia del Parlamento. Y, en todo caso, la tesis de la ineficacia o incluso la invalidez de la forma parlamentaria de gobierno parece que debiera desembocar, coherentemente, en la propuesta de su sustitución por el régimen presidencial; es decir, por una forma de gobierno (también democrática) en la que ya no pueden darse los "defectos" que él denuncia. No es esa, sin embargo, la solución que Schmitt propugna. Su apuesta por el presidencialismo en la Alemania de Weimar no tendría nada que ver con lo que significa el régimen presidencial democrático. El "presidencialismo" de Schmitt lo que suponía, sencillamente, era una "dictadura presidencial", que es cosa bien distinta.

La crítica al parlamentarismo no conduce a nuestro autor a postular la adopción del presidencialismo democrático, porque ello supondría admitir que en ese tipo de régimen el Parlamento (al que ya no puede achacársele que domine al gobierno ni que sea dominado por éste) sigue desempeñando una función esencial (en la teoría y en la práctica, como se prueba en el ejemplo más característico, que es el norteamericano). Si lo que verdaderamente se pretendía (y esa es la clave de la tesis schmittiana) es criticar al Parlamento como institución, entonces la simple crítica al parlamentarismo como forma de gobierno, poco consistente incluso en ese plano interno, servía, en realidad, de muy poco. Había que acudir, pues, a otra crítica, externa al propio parlamentarismo como régimen. Era preciso disparar por elevación. Ir, en fin, 
Este libro forma parte del acervo de la Biblioteca Jurídica Virtual del Instituto de Investigaciones Jurídicas de la UNAM

a la raíz del asunto: efectuar la crítica no ya al parlamentarismo como forma de gobierno, sino al parlamentarismo como forma de Estado. Es decir, a la democracia parlamentaria como sistema. Y eso es, precisamente, lo que hará Schmitt en el Prefacio a la segunda edición de su ensayo sobre el parlamentarismo para contestar a la crítica, razonable, de Thoma, y lo que desarrollará, de ahí en adelante, en el resto de sus escritos.

Esta crítica, ya en el plano de la forma de Estado, será, en realidad, la importante o genuina crítica de Schmitt al parlamentarismo, la que se enfrenta con el problema sustancial: el de la democracia representativa. Y en ese plano no caben distinciones radicales o antagónicas (es decir, "schmittianas") entre parlamentarismo y presidencialismo como regímenes distintos (al fin y al cabo sus diferencias no son sustantivas, en cuanto que ambos regímenes son únicamente especies de un mismo género, el de la democracia parlamentaria). La anterior crítica al régimen parlamentario de gobierno queda reducida a su verdadero y secundario papel: un ejercicio más bien de dispersión. La cuestión principal aparece ya enteramente desvelada: la crítica al parlamentarismo como crítica a la misma institución del Parlamento, esto es, a la democracia parlamentaria o, más radicalmente aún, a la democracia representativa.

\section{Crítica al parlamentarismo como forma de Estado}

La crítica a la democracia parlamentaria se articulará, a su vez, en tres planos. El primero estará referido al significado de la propia democracia, sosteniendo Schmitt la disociación entre democracia y libertad (y, por lo mismo, entre representación y elección). La democracia no se basa en la libertad, dirá, sino en la homogeneidad. De ahí que, a su juicio, la democracia representativa sólo sea posible cuando la entidad representada (la nación) es homogénea; es decir, cuando tiene un solo interés (que es lo que ocurre con la reducción de la nación a la burguesía en el siglo XIX), pero no cuando aquella entidad es heterogénea (nación 
Este libro forma parte del acervo de la Biblioteca Jurídica Virtual del Instituto de Investigaciones Jurídicas de la UNAM

coincidente con pueblo, que es lo que sucede cuando existe el sufragio universal, del que dispone toda una sociedad que, a su vez, está dividida en clases o en grupos con intereses contrapuestos).

Una sociedad así - seguirá argumentando - es incompatible con la democracia liberal (la democracia parlamentaria) puesto que el enfrentamiento de intereses conduciría siempre al dominio político de una clase sobre otra (dominio, dirá, disfrazado de "democracia formal", coincidiendo así Schmitt, sintomáticamente, con el marxismo). El Parlamento no serviría entonces para "representar" a todos, sino para que se impusiese, a través suyo, la clase dominante.

La democracia, en consecuencia, no es conciliable con el "pluralismo", sino sólo con la homogeneidad; el concepto mismo de "democracia pluralista" sería, para Schmitt, un contrasentido. De ahí que, cuando la propia sociedad es "plural", el único modo de hacer posible la democracia reside en la negación de la "pluralidad", bien destruyéndola (en su estudio sobre el parlamentarismo dirá, literalmente, que "el poder político de una democracia estriba en saber eliminar o alejar lo extraño y desigual, lo que amenaza la homogeneidad") o bien silenciándola, es decir, excluyéndola de la "representación".

En este último sentido, distingue Schmitt entre Vertretung, o representación mediante elecciones, que es siempre, a su juicio, una representación política inauténtica; es decir, una representación de intereses (de ahí que por basarse en las elecciones, como dirá en su estudio sobre el parlamentarismo, "el sistema democrático resulta ser, en fin, una mala fachada del dominio de los partidos y de los intereses económicos"), y Repräsentation, o representación "espiritual", que se manifiesta no por la elección, sino por la "identificación" del pueblo con sus líderes (mediante la "aclamación" o el "asentimiento").

Esta Repräsentation, única representación auténtica, no se verifica, pues, a través de procedimientos, ya que es algo "existencial". Por ello, el representante no es un delegado de la voluntad de los representados, ya que, por principio, como esa voluntad no 
Este libro forma parte del acervo de la Biblioteca Jurídica Virtual del Instituto de Investigaciones Jurídicas de la UNAM

existe (lo que hay es una diversidad de voluntades antagónicas), es imposible que pueda delegarse; por el contrario, mediante esa "representación", el representante "encarna" lo que hay de homogéneo en los representados, expresando así (o dando vida a) una voluntad popular que sólo es capaz de manifestarse (o hacerse presente) por obra del representante mismo, de su cualidad para "identificarla". Esa es la auténtica democracia, se dirá, frente a la falsa democracia representativa.

A partir de ahí, de ese concepto de "representación" (y de ese entendimiento de la democracia), no es de extrañar que Schmitt afirme que la democracia es cosa distinta de las votaciones secretas, que democracia y dictadura no son términos inconciliables, que (y así lo dice exactamente en su estudio sobre el parlamentarismo) "bolchevismo y fascismo son, como cualquier dictadura, antiliberales, pero no necesariamente antidemocráticos".

Como puede observarse, la confluencia entre ideas de extrema izquierda y de extrema derecha es clara: bajo la apelación de Schmitt a una "auténtica democracia" (frente a la inauténtica o "formal" democracia parlamentaria) lo que se esconde es la destrucción de la democracia misma. Cuando a la democracia se le amputa la libertad, no queda convertida en "otro tipo" de democracia, sino, sencillamente, en dictadura.

El otro plano de la crítica a la democracia parlamentaria se expresa a través del rechazo al Parlamento-legislador. La ley, se dirá por Schmitt, era norma "general" porque era expresión de una voluntad "general" y porque su emanación era el producto de una discusión "general" (libre intercambio de "razones" individuales). Producto de la discusión de unos parlamentarios que representaban intereses homogéneos, la ley aparecería en el parlamentarismo del siglo XIX como la manifestación de la razón (de la "verdad" que se abría paso a través de un proceso de libre debate). Esta consideración de la ley, dirá Schmitt, es consustancial con la democracia parlamentaria. Pero ocurre, seguirá diciendo, que en el Parlamento de nuestro tiempo es imposible la "discusión", la capacidad de mutuo convencimiento, porque allí 
Este libro forma parte del acervo de la Biblioteca Jurídica Virtual del Instituto de Investigaciones Jurídicas de la UNAM

están representados intereses contrapuestos y, en consecuencia, la ley será sólo la imposición de unos intereses sobre otros o, en el mejor de los casos, la transacción entre intereses, pero nunca el producto racional de la discusión. Más aún, ya no hay discusión pública parlamentaria, pues las decisiones, los compromisos, se adoptan fuera del Parlamento, viniendo éste a ser únicamente un instrumento de mera votación o ratificación de algo ya configurado y decidido al margen de la cámara. Hoy ya no existe, pues, el Parlamento-legislador y, en consecuencia, tampoco existe la democracia parlamentaria, que se sustentaba precisamente en esa categoría. Lo único que queda es una forma vacía, periclitada, que está en contradicción con los tiempos modernos.

Hay que decir que esta crítica, aguda, no es por entero rigurosa. En ese sentido, parece claro que Schmitt, además de construir un modelo ideal de parlamentarismo que nunca existió (Parlamentos que representaban intereses totalmente homogéneos, parlamentarios que sólo se guiaban en la discusión por su libre razón y no por su coartada voluntad, leyes que no necesitaban nunca de acuerdos, de compromisos adoptados fuera de la sede física del Parlamento) para denostarlo porque no existe ya en su época, cierra los ojos ante la evidencia de que la atribución de la capacidad de legislar (por delegación del Parlamento) al gobierno no tiene por qué ser incompatible con la democracia parlamentaria, de que la "concertación" social y económica no es inconciliable con el parlamentarismo, de que tampoco lo es la negociación entre partidos y no exclusivamente entre parlamentarios, de que la imposición del contenido de la ley por la mayoría no deja sin sentido la función de publicidad y de control del procedimiento Legislativo parlamentario y, en general, de los demás procedimientos de adopción de decisiones en el Parlamento democrático.

Sin embargo, no puede ocultarse la parte de veracidad que en la crítica se encierra. El actual Parlamento de "partidos" y las nuevas formas de adopción de decisiones estatales por medio de la "concertación" social, política y económica, han transformado 
Este libro forma parte del acervo de la Biblioteca Jurídica Virtual del Instituto de Investigaciones Jurídicas de la UNAM

muy profundamente la praxis de la democracia parlamentaria. A Schmitt no puede negársele el mérito de desvelar esas transformaciones y alertar sobre los peligros que se encierran en una práctica alejada de la teoría. Lo que sí cabe reprochársele es que absolutice los términos del problema, presentando esas transformaciones y esos riesgos como prueba, indudable, de la destrucción de la democracia parlamentaria. Introduciendo en la crítica schmittiana la relatividad de que carecía en su rotunda formulación, puede ser hoy, muy probablemente, la parte de las reflexiones de Schmitt que ha perdido menos actualidad.

El último plano de la crítica de Schmitt a la democracia parlamentaria se vertebra alrededor de su crítica a la democracia "procedimental". Si es ley - dirá-, lo que quiera el legislador, es decir, lo que quiera la mayoría, entonces la democracia es sólo el dominio total (el absolutismo) de la mayoría parlamentaria, que en cualquier momento podrá decidir qué es lo legal y lo ilegal. La democracia parlamentaria, concluye Schmitt, lo que encubre es la dictadura de la mayoría, que no deja de serlo (dictadura) porque cada cierto número de años haya elecciones. Se ha eliminado la tiranía por injusto título, pero se ha aceptado la tiranía por injusto ejercicio.

Este tipo de razonamiento, en el que hay fisuras, desde luego, es, sin embargo, el que parece intelectualmente más sólido, a mi juicio, en toda la construcción schmittiana y, como va a ser también (en sentido contrario) la piedra angular de la defensa que hará Kelsen del parlamentarismo, parece conveniente examinarlo a contraluz de las ideas de éste.

\section{Kelsen contra Schmitt}

La decidida defensa del parlamentarismo acometida por Kelsen en aquellos mismos años ${ }^{9}$ está articulada de manera más li-

9 Principalmente en Von Wesen und Wert der Demokratie, 1920; Demokratisierung der Verwaltung, 1921; Das Problem des Parlamentarismus, 1925; Demokratie, 1926. La obra de 1920, revisada y ampliada en 1929, está traducida (a partir de esta 2a. 
Este libro forma parte del acervo de la Biblioteca Jurídica Virtual del Instituto de Investigaciones Jurídicas de la UNAM

neal que la crítica de Schmitt, Kelsen parte de que el parlamentarismo, en sentido genuino, debe considerarse como forma de Estado (se refiere muy poco, consciente de que no es capital en la polémica que se estaba desarrollando, al parlamentarismo como forma de gobierno), sosteniendo, con razón, que la sustancia del problema no es más que el debate entre autoritarismo y democracia. Puesto que la democracia directa, como modo de ejercicio del poder, no es posible en el Estado moderno (otra cosa es que se entienda por democracia directa su falsificación), no hay más democracia posible en nuestro tiempo - dirá Kelsen- que la democracia parlamentaria. Merece la pena transcribir exactamente lo que dejó escrito sobre ello:

Aunque la democracia y el parlamentarismo no son términos idénticos, no cabe dudar en serio - puesto que la democracia directa no es posible en el Estado moderno- de que el parlamentarismo es la única forma real en que se puede plasmar la idea de la democracia dentro de la realidad social presente. Por ello, el fallo sobre el parlamentarismo es, a la vez, el fallo sobre la democracia. ${ }^{10}$

Inmediatamente, Kelsen denunciará el error de criticar al parlamentarismo por el expediente de construir un tipo ideal falseado de lo que "debe ser" y contraponerlo a lo que en la realidad "es". No es esa, dirá, la manera rigurosa de entender el parlamentarismo:

La llamada crisis del parlamentarismo ha sido suscitada, en gran parte, por una crítica que interpreta equivocadamente la esencia de esta forma política y que, por consiguiente, no comprende bien su valor. Pero, ¿cuál es la esencia del parlamentarismo? ¿Cuál es

ed.) al español desde 1934: Esencia y valor de la democracia; en ella se contienen los argumentos sustanciales de Kelsen en defensa de la democracia parlamentaria. En adelante ésta será la obra que citaremos, en su edición española más actual (Barcelona, 1977).

10 Esencia y valor de la democracia, cit., p. 50. 
Este libro forma parte del acervo de la Biblioteca Jurídica Virtual del Instituto de Investigaciones Jurídicas de la UNAM

la esencia objetiva que no debe confundirse con la interpretación subjetiva que, por motivos conscientes o inconscientes, tratan de dar los partícipes o interesados en esta institución? El parlamentarismo significa: Formación de la voluntad decisiva del Estado mediante un órgano colegiado elegido por el pueblo en virtud de un derecho de sufragio general e igual, o sea, democrático, obrando a base del principio de mayoría. ${ }^{11}$

Lo característico es que la voluntad decisiva del Estado, esto es, la ley, se adopta en el Parlamento democrático. No hay más que dos formas de Estado porque no hay más que dos formas de emanación del derecho: autocracia y democracia. En la primera, el derecho (más exactamente, su norma primaria, la ley) emana de arriba abajo; en la segunda, de abajo arriba, a través del Parlamento formado por representantes del pueblo democráticamente elegidos, Parlamento que funciona, a su vez, a través del principio democrático de la mayoría. La división de la sociedad en clases, o en estratos o en grupos con intereses contrapuestos, no es obstáculo para que el Parlamento (de composición política plural) represente a esa sociedad plural (o, más exactamente, para que esa sociedad plural designe a sus plurales representantes de manera libre y democrática), ni es obstáculo para que la ley sea producto de la deliberación, del acuerdo y del compromiso; no hay ninguna razón teórica ni ninguna exigencia práctica para que, en la democracia, se sustituya la representación política por la de intereses, los Parlamentos por las cámaras corporativas; la victoria de la mayoría no produce la aniquilación de la minoría, sino un sistema en el que la minoría tiene también derechos y en el que la igualdad de chance presta dinámica y legitimidad al ejercicio del poder.

Ahora bien, Kelsen es consciente de que la democracia parlamentaria es combatida por la extrema derecha y por la extrema izquierda por motivos más descarnadamente "políticos" (de pura toma del poder a cualquier precio) que "intelectuales", y así dirá: 
Este libro forma parte del acervo de la Biblioteca Jurídica Virtual del Instituto de Investigaciones Jurídicas de la UNAM

Ocurre que la extrema izquierda del partido proletario abandona el ideal democrático creyendo que el proletariado no puede conquistar el poder dentro de esta forma, al menos en plazo previsible, mientras que la extrema derecha de los partidos burgueses hace lo mismo, pensando que la burguesía no podrá defender el poder político, siquiera por mucho tiempo, dentro de la democracia. En el oscuro horizonte de nuestro tiempo, asoma el rojo resplandor de un astro nuevo: la dictadura de partido, dictadura socialista del proletariado, o dictadura nacionalista de la burguesía; tales son las dos nuevas formas de la autocracia. ${ }^{12}$

La observación no podía ser más exacta. En fin, para cerrar la argumentación, Kelsen sostendrá que precisamente no hay contradicción posible entre la pluralidad (con el consiguiente enfrentamiento) de intereses y valores que caracteriza a las sociedades desarrolladas del siglo XX, y el parlamentarismo (esto es, la democracia parlamentaria) como sistema, ya que la democracia no tiene un sentido material, sino sólo y exclusivamente formal: "es una manifiesta corrupción de la terminología aplicar el vocablo «democracia», que tanto ideológica como prácticamente significa un determinado método para la creación del orden social, al contenido de este mismo orden, que es cosa completamente independiente". ${ }^{13}$

La democracia es método y sólo método, dirá, y se corresponde no con el dogmatismo, sino exactamente con el relativismo. Merece la pena reproducir (aunque sea extenso) lo escrito por Kelsen al respecto:

Del espíritu de esta filosofía [se refiere a la filosofía absolutista] proviene el célebre lema: "autoridad, no mayoría". Y, en efecto, si se cree en la existencia de lo absoluto - de lo absolutamente bueno, en primer término-, ¿puede haber nada más absurdo que provocar una votación para que decida la mayoría sobre ese absoluto en que se cree? Frente a la autoridad de este sumo bien

12 Esencia y valor de la democracia, cit., p. 130.

13 Ibidem, p. 127. 
Este libro forma parte del acervo de la Biblioteca Jurídica Virtual del Instituto de Investigaciones Jurídicas de la UNAM

no puede haber más que la obediencia ciega y reverente para con aquel que, por poseerlo, lo conoce y lo quiere; si bien es verdad que esta obediencia presupone la creencia igualmente incondicionada de que la persona autoritaria del caudillo se halla en posesión del bien sumo, cuyo conocimiento está vedado a la gran masa de los dirigidos. Pero, si se declara que la verdad y los valores absolutos son inaccesibles al conocimiento humano, ha de considerarse posible al menos no sólo la propia opinión, sino también la ajena y aun contraria. Por eso, la concepción filosófica que presupone la democracia es el relativismo. La democracia concede igual estima a la voluntad política de cada uno, porque todas las opiniones y doctrinas políticas son iguales para ella, por lo cual les concede idéntica posibilidad de manifestarse y de conquistar las inteligencias y voluntades humanas en régimen de libre concurrencia. Tal es la razón del carácter democrático del procedimiento dialectivo de la discusión, con el que funcionan los Parlamentos y Asambleas populares. Por eso mismo, el poder mayoritario de la democracia no es posible sin una minoría oposicionista a la que ineludiblemente ha de proteger. Y, por eso también, la política democrática es transaccional, del mismo modo que el relativismo tiende a procurar la compensación de los puntos de vista contrapuestos, ninguno de los cuales puede aceptarse íntegramente y sin reservas, y con negación completa del otro. La relatividad del valor de cualquier fe política, la imposibilidad de que ningún programa o ideal político pretenda validez absoluta (pese a la desinteresada dedicación subjetiva y la firme convicción personal de quien lo profesa), inducen imperiosamente a renunciar al absolutismo en política: sea el absolutismo de un monarca, de una casta sacerdotal, aristocrática o guerrera, de una clase o de cualquier grupo privilegiado. ${ }^{14}$

Justamente el relativismo, que a Kelsen le parece la virtud, más aún, el presupuesto de la democracia (democracia "procedimental" y no "sustantiva"), a Schmitt le parece, en cambio, su mayor defecto, el principio contradictorio con la democracia misma. Para Schmitt, como ya se vio, la democracia no puede

14 Ibidem, pp. 156 y 157. 
Este libro forma parte del acervo de la Biblioteca Jurídica Virtual del Instituto de Investigaciones Jurídicas de la UNAM

fundarse en el pluralismo, sino en la homogeneidad: "El método de formación de la voluntad por la simple verificación de la mayoría tiene sentido y es admisible cuando puede presuponerse la homogeneidad sustancial de todo el pueblo". ${ }^{15}$ Cuando esa homogeneidad no existe, es decir, cuando se "acepta" la pluralidad (porque no se la destruye o se la silencia), la democracia es imposible y la regla de la mayoría aparece como un instrumento de la dictadura (aunque sea una dictadura de la mayoría). Y así dirá:

Si se suprime el presupuesto de la homogeneidad nacional indivisible, entonces el funcionalismo sin objeto ni contenido, resultante de la verificación puramente aritmética de la mayoría, excluirá toda neutralidad y toda objetividad; será tan sólo el despotismo de una mayoría cualitativamente mayor o menor sobre la minoría vencida en el escrutinio y, por tanto, subyugada. ${ }^{16}$

Quien tenga la mayoría "ya no cometerá injusticias, pues todo lo que haga se convierte en Derecho y en legalidad". ${ }^{17}$

Aparte de que Schmitt silencie que la mayoría que, a través de la ley, privase de igualdad de chance a la minoría no estaría realizando la democracia, sino destruyéndola, y lo silencia porque para él la libertad no forma parte inescindible de la democracia (al contrario de lo que sostiene Kelsen), aparte de que también silencie el control social que, frente a los abusos de la mayoría, puede efectuar la opinión pública (y lo silencia por los mismos motivos anteriores: el control social sólo puede operar si hay libertad), al margen, pues, de la muy distinta concepción de democracia de que se parte en una y otra postura, lo cierto es que aquí, en lo que atañe exclusivamente a la denuncia de los riesgos que puede comportar un entendimiento puramente "procedimiental" de la democracia, se encuentra un sólido argumento de Schmitt que no queda por entero rebatido en la tesis de Kelsen.

\footnotetext{
15 Legalidady legitimidad, Madrid, 1971, p. 42.

16 Ibidem, p. 43.

17 Ibidem, p. 46.
} 
Este libro forma parte del acervo de la Biblioteca Jurídica Virtual del Instituto de Investigaciones Jurídicas de la UNAM

Una democracia totalmente procedimental y un Estado (un derecho, habría que decir) ideológicamente neutral exigen entonces una Constitución, concluirá Schmitt (y en ello coincidirá, sustancialmente, con Kelsen), "que tiene que limitarse fundamentalmente a regulaciones orgánicas y de procedimiento". ${ }^{18} \mathrm{En}$ ese modelo constitucional los derechos de los ciudadanos (y de las minorías), quedarían, "jurídicamente", en manos del legislador; el Estado de derecho sería un Estado constitucional desde el punto de vista procedimental o "formal", pero sería sólo un mero Estado "legal" desde el punto de vista material.

Ese es el problema teórico más agudo al que el parlamentarismo (la democracia parlamentaria) tendría que dar respuesta: el de las limitaciones jurídicas del mismo Parlamento desde el punto de vista material o, si se quiere, el de los límites sustantivos (y no sólo procedimentales) del propio legislador. Kelsen no eludió, desde luego, ese problema, al defender la conveniencia (más aún, la necesidad) de los tribunales constitucionales, pero su misma concepción de la justicia constitucional (y de la eficacia jurídica de las normas constitucionales) no significaba una solución completa al problema planteado. La respuesta, que no supondría la negación de la democracia parlamentaria, sino su reafirmación mediante un proceso de adaptación y modificaciones, no se produciría plenamente en Europa hasta después de la Segunda Guerra Mundial.

Mientras tanto, la crisis política del periodo de entreguerras, el enfrentamiento entre parlamentarismo y antiparlamentarismo, se saldaría en Alemania (como en Italia, España o Portugal) con el triunfo del antiparlamentarismo; esto es, con el aplastamiento de la democracia y el establecimiento de una de aquellas dos nuevas formas de dictadura que denunciaba Kelsen: la dictadura nacionalista (o fascista) de derechas. En la Unión Soviética el antiparlamentarismo ya había triunfado, asentándose la otra nueva forma de dictadura: la dictadura del proletariado.

18 Ibidem, p. 39. 
Este libro forma parte del acervo de la Biblioteca Jurídica Virtual del Instituto de Investigaciones Jurídicas de la UNAM

\section{GARL SchmitT ENTRE EL PASADO Y EL PRESENTE. LA SITUACIÓN ACTUAL DEL PARLAMENTARISMO}

La derrota bélica de Alemania e Italia supuso para aquellos países la vuelta al régimen constitucional, después de una larga dictadura fascista. Se recuperaba así el parlamentarismo, pero con algunas correcciones respecto del viejo sistema, derivadas de las enseñanzas que proporcionaron las pasadas crisis. Por supuesto que en las nuevas Constituciones alemana e italiana se establecía una verdadera democracia parlamentaria que descansaba en la libertad y en el sufragio universal. Ese principio, como es obvio, no podía ponerse en duda. Ya se sabía muy bien adónde conducía la disociación teórica entre libertad y democracia y entre elección y representación.

Las transformaciones no afectaban a los principios nucleares de la democracia representativa como sistema, pero sí a determinados (e importantes) elementos de éste: a los partidos políticos, a los que se confería reconocimiento constitucional, admitiéndose sin reparos su papel de actores fundamentales de la vida política y, especialmente, de la actividad parlamentaria; al gobierno y a la administración, a los que se reforzaba y, sobre todo, encomendaba la realización de tareas de intervención "positiva" para procurar el "bienestar" de los ciudadanos, reducir las desigualdades y, en definitiva, moderar los desequilibrios económicos y sociales; a la organización territorial del Estado, estableciéndose (o restableciéndose, según los casos) una descentralización política que no sólo acerca el poder al ciudadano, sino que supone un límite más para el poder mismo, en cuanto que a su división funcional se añade la territorial; a la ley, como categoría y, por ello, a la libertad de acción de las mayorías parlamentarias, consagrándose un tipo de Constitución normativa, directamente aplicable (aunque sus distintas normas tengan diversa eficacia), que contiene cláusulas materiales (y no sólo procedimentales) que se imponen al legislador y que, en consecuencia, limitan su voluntad, de tal manera que ésta ya no será enteramente libre, sino que estará su- 
Este libro forma parte del acervo de la Biblioteca Jurídica Virtual del Instituto de Investigaciones Jurídicas de la UNAM

mamente condicionada, sujeta a la observancia de unos derechos de libertad y de igualdad establecidos por la Constitución.

Esta última característica (pieza vertebral del "nuevo parlamentarismo", bien enraizada en la historia constitucional norteamericana, y que había sido ensayada, aunque limitadamente, en los años veinte y treinta en Austria y España, pero que no será hasta después de 1945 cuando se instale sólidamente, y con toda plenitud, en parte del territorio europeo) lo que viene a significar es el intento de conseguir un equilibrio entre la garantía constitucional del pluralismo político o, si se quiere, del relativismo ideológico (de la democracia procedimental) sin lo cual, como decía Kelsen, no hay democracia, y la imposición constitucional de determinados valores (democracia sustantiva o material) sin los cuales no hay libertad-igualdad, imposición que puede evitar el "absolutismo" de la mayoría denunciado por Schmitt.

La clave de tal equilibrio, con el que se pretende superar el enfrentamiento entre democracia procedimental y democracia sustantiva, entre la Constitución como "norma abierta" y la Constitución como "sistema material de valores", ${ }^{19}$ reside en la creación y funcionamiento de los Tribunales Constitucionales, instituciones sin las cuales es muy difícil (salvo en el caso todavía peculiar del Reino Unido) comprender teóricamente y organizar prácticamente el parlamentarismo democrático, forma política en la que el Parlamento sigue siendo el eje del sistema (aunque el gobierno sea el poder "más fuerte") porque es el "centro" de su legitimidad y de su actividad normativa, pero cuyas decisiones pueden ser controladas, ya que la ley, aunque continúe ostentado el papel de norma "primordial", ha dejado de ser, sin embargo, la norma "primaria" del ordenamiento, que lo es la Constitución, cuyas prescripciones "materiales" (y no sólo "estructurales") se imponen a todos los poderes del Estado. La mayoría decide, pero

19 Aragón, M., "El control como elemento inseparable del concepto de Constitución", Revista Española de Derecho Constitucional, Madrid, núm. 19, 1987, en especial pp. 37-49, y Constitución y democracia, Madrid, 1990, en especial pp. 23-53. 
Este libro forma parte del acervo de la Biblioteca Jurídica Virtual del Instituto de Investigaciones Jurídicas de la UNAM

no libremente; la mayoría controla, pero también es controlada; los ciudadanos (y las minorías) poseen unos derechos que la mayoría no puede vulnerar; ya no es justo ("jurídicamente") lo que la mayoría quiera, sino lo que la mayoría acuerde "de conformidad" con lo dispuesto en la Constitución.

Y este nuevo parlamentarismo, que se extendió sobre las cenizas del antiparlamentarismo totalitario en Italia y la República Federal de Alemania, también acabó estableciéndose, en sustitución de otro parlamentarismo autoritario similar, en Portugal y España. Aquí también se produciría, ya en los años setenta, la recuperación de la democracia, que, como no podía ser de otro modo, significaba la recuperación del parlamentarismo, del parlamentarismo como forma de Estado (hoy que, además, las diferencias entre las formas de gobierno "parlamentaria" y "presidencial", dentro de la democracia, tienden a difuminarse), esto es, como decía Kelsen, del sistema en el cual las decisiones fundamentales del Estado se adoptan por un órgano colegiado designado periódicamente por el pueblo mediante elecciones disputadas, libres, por sufragio universal e igual.

Hoy parece que el antiparlamentarismo se encuentra en franca retirada (incluido el de ascendencia marxista, como lo prueban los acontecimientos últimos de la Europa del Este), pero la suerte del parlamentarismo en el futuro dependerá de su capacidad para autolegitimarse, y ello presupone, de un lado, la prevalencia de la tolerancia sobre el dogmatismo en la vida política y, de otro, la constante necesidad (o, si se quiere, el reto cotidiano) de revitalizar la representación, de vigorizar los debates parlamentarios, de mejorar, técnicamente, la legislación, de acentuar la función parlamentaria de control, al objeto de que no decrezca la importancia política del Parlamento a los ojos de los ciudadanos; ${ }^{20}$

20 Aragón, M., "El control parlamentario como control político", Revista de Derecho Político, núm. 23, 1986, y "La función legislativa de los Parlamentos y sus problemas actuales", Garrorena, A. et al., El Parlamento y sus transformaciones actuales, Madrid, Tecnos, 1990, pp. 129-143; y, sobre todo, Rubio Llorente, F., "Parlamento y representación política", en I fornadas de Derecho Parlamentario, 
Este libro forma parte del acervo de la Biblioteca Jurídica Virtual del Instituto de Investigaciones Jurídicas de la UNAM

pero, sobre todo, presupone la existencia de una sociedad, plural, sí, pero no fuertemente dividida por la desigualdad.

Desde este presente del parlamentarismo, la lectura del libro de Carl Schmitt a los sesenta y siete años de su aparición, supone, por una parte, sumergirse en el pasado, en una época crispada y agónica como fue la de los años veinte en Alemania, y, por otra, preguntarse, inevitablemente, si superada ya, por fortuna, aquella situación siguen, no obstante, perviviendo algunas de aquellas ideas.

Las ideas de Schmitt no desentonaban mucho en el "clima espiritual" de aquel tiempo, azotado por el vendaval de tantos absolutismos (marxismo, anarquismo, fascismo) que parecían eclipsar la vieja doctrina ilustrada de que sólo en libertad puede vivir la razón. Una sociedad fuertemente escindida y una vida intelectual sumida en radicales antagonismos dejaban muy poco espacio al relativismo, es decir, a la tolerancia. Schmitt se incluiría, desde luego, en ese amplio bando de los radicalismos, la política se reduciría, para él, a la distinción, neta, entre amigo y enemigo; la actividad política, en consecuencia, no habría de sustentarse en la discusión, sino en la decisión.

No parece, sin embargo, que deba incluirse el "decisionismo" schmittiano dentro de las corrientes "irracionalistas"; su dogmatismo intelectual lo acercaba, más bien, al pensamiento "idealista" y lo alejaba tanto del "irracionalismo" como del "cientificismo". En ese sentido, resulta muy revelador que, en el amplio capítulo que dedica, en el libro, al marxismo, subraye más de una vez lo que hay en éste de "idealismo" y advierta (con agudeza) que es precisamente en lo que tiene también de "cientificismo" donde se encierra su mayor debilidad, pues al jugar así en el propio campo de la burguesía (el de la "racionalidad económica") acabaría, más tarde o más temprano, por perder la par-

Madrid, 1985, vol. I, pp. 143-170; así como Garrorena, A., "Apuntes para una revista crítica de la teoría de la representación", Garrorena, A. et al., El Parlamento y sus transformaciones actuales, cit., pp. 27-63.

21 Estévez Araujo, J. A., La crisis del Estado..., cit., pp. 140-151. 
Este libro forma parte del acervo de la Biblioteca Jurídica Virtual del Instituto de Investigaciones Jurídicas de la UNAM

tida. Como resulta también revelador que vea, más aún que en el marxismo o en el anarquismo, en las doctrinas irracionalistas exaltadoras de la acción directa y del empleo de la violencia física (esencialmente en Sorel, a cuyas principales ideas dedicará buena parte de otro capítulo del libro) el enemigo más potente y actual de la democracia parlamentaria. No se equivocaba mucho, por lo menos en cuanto al futuro inmediato de Alemania.

No obstante, y aun atribuyendo a esas "nuevas fuerzas" tanta importancia política, la exposición que hace Schmitt de las corrientes irracionalistas es de un nivel analítico muy inferior a la que también hace del marxismo. Para éste hay mayor "comprensión"; para aquéllas, mayor "descripción”. No es casual, en modo alguno, que Schmitt "comprenda" mejor el marxismo (o lo que de "idealismo" hay en el marxismo); al fin y al cabo, a éste le aproxima su concepción teológica de la política. Probablemente Schmitt ha sido, con un siglo de retraso, el último de los pensadores contrarrevolucionarios, el más genuino heredero de De Bonald, De Maistre y Donoso Cortés. A él podría aplicársele lo mismo que dice, en el libro, del propio Donoso: "Para Cortés, el socialismo radical es algo incomparablemente mejor que la transigencia liberal, porque lleva a los problemas últimos y porque da una respuesta a las preguntas radicales, dado que posee una teología".

¿Se podía ser tan antiliberal como Donoso sin ser tan antiburgués como Sorel? En otras palabras, ¿se podía ser conservador reaccionario sin desembocar en el fascismo? Ese es el dilema en que, al final, se vio envuelto Schmitt. Su doctrina no podría desligarse, objetivamente, del nacionalsocialismo, ${ }^{22}$ como tampoco su misma persona. Aunque después hubiese permanecido neutral

22 Maus, Ingerbor, Bürgerliche Rechtstheorie und Faschismus. Zur sozialen Funktion und aktuellen Wirkung der Theorie Carl Schmitts, Múnich, 1980; Neumnn, Volker, Der Staat im Bürgerkrieg. Kontinuität und Wandlung des Staatsbegriffes in der politischen Theorie Carl Schmitts, Fráncfort, 1980, y "Vom Entscheidungs-zum Ordnungsdenken. Carl Schmitts Rechts-und Staatstheorie in der nationalsozialistischen Herausforderung", Archiv für Rechts-und Sozialphilosophie, Beiheft, Alemania, núm. 18, 1983. 
Este libro forma parte del acervo de la Biblioteca Jurídica Virtual del Instituto de Investigaciones Jurídicas de la UNAM

(que no fue así) ante los desmanes nazis, no bastaría el mero silencio como exculpación, aquello que le decía a Jünger para explicar su situación ante la violencia y la irracionalidad (después de compararse con el capitán del barco negrero dominado por los esclavos sublevados que aparece en el Benito Cereno de Melville): Nom possum scribere contra eum, qui potest proscribere. ${ }^{23}$ Otros (como Kelsen), cuando pudieron escribir (como él) sin que los proscribiesen, escribieron (a diferencia de él) a favor de la tolerancia y en contra del absolutismo; y cuando fueron (como Kelsen) después proscritos (a diferencia de lo que le ocurrió a él), siguieron escribiendo, desde el exilio, en defensa de la libertad.

Pero no se trata de extenderse ahora en juicios retrospectivos. Más interés tiene alertar sobre los nuevos dogmatismos (nacionalismos, racismos, fundamentalismos) que hoy aparecen en el horizonte y que pudieran constituir en el futuro, otra vez, y con distintos rostros, el mayor peligro para la democracia parlamentaria. Desde ese punto de vista, el libro de Schmitt no deja de ser, desde luego, un buen acicate para que la razón no vuelva a adormecerse.

23 Jünger, E., Radicaciones. Diarios de la Segunda Guerra Mundial, Barcelona, 1989, p. 244. 


\section{SISTEMA PARLAMENTARIO, SISTEMA PRESIDENGIALISTA Y DINÁMICA ENTRE LOS PODERES DEL ESTADO. ANÁLISIS COMPARADO}

\section{OBJETIVO}

La primera parte del capítulo lo dedicaré a la relación entre la democracia y el control de los poderes públicos, la segunda a las diferencias actuales entre parlamentarismo y presidencialismo, la tercera al papel del Parlamento en la actualidad, la cuarta al significado del control parlamentario como elemento fundamental de la forma de Estado democrático parlamentaria y la quinta y última a la relación actual entre los poderes públicos o, dicho con otras palabras, a la situación presente de la división de poderes.

\section{DEMOGRAGIA Y CONTROL DEL PODER}

Como la práctica ha demostrado y la razón reconoce, la libertad de los ciudadanos sólo puede garantizarse si el poder se encuentra limitado. De ahí que esa libertad sea incompatible con el poder absoluto, aunque éste se atribuya al pueblo. La democracia directa, que quizá pueda ser un complemento eficaz de la democracia representativa, no es capaz, sin embargo, de organizar, por sí sola, un sistema de gobierno respetuoso con la libertad, ya que ésta no es producto de la identidad, sino de la distinción. Por ello, el Estado constitucional, cuya base es la democracia representativa y cuya estructura descansa en la división del poder, ha sido la única 
Este libro forma parte del acervo de la Biblioteca Jurídica Virtual del Instituto de Investigaciones Jurídicas de la UNAM

forma histórica, hasta hoy, capaz de garantizar al mismo tiempo la libertad y la democracia (ambos términos, en realidad, se requieren mutuamente, puesto que la libertad de los ciudadanos sólo está asegurada si la soberanía pertenece al pueblo y éste es soberano únicamente si está compuesto por personas libres).

Siempre al dividir se distribuye, por eso la división del poder significa su distribución: una distribución de potestades y de competencias; esto es, de capacidad de actuar, que supone la asignación de medios, pero también de ámbitos para ejercitarlos. Si no hay distribución, obviamente no hay limitación. De ahí la ineficacia de una división que distribuyese con arreglo a criterios exclusivamente formales. Para que la distribución (y con ello la limitación) sea efectiva, ha de articularse, además, a través de criterios materiales. Y así ocurre en el conjunto de divisiones que caracterizan al Estado constitucional.

En primer lugar, en la división más básica o primaria: la que distingue el Poder Constituyente del poder constituido. Distinción que da el ser a la Constitución misma y que se basa tanto en ingredientes formales (el modo de actuar del Poder Constituyente - aquí vale decir del poder de emanar la Constitución y de cambiarla - ha de tener unas formalidades diferentes al modo de actuar del poder constituido), como en ingredientes materiales (el poder constituido no puede hacer lo mismo que el Poder Constituyente, esto es, ha de ser un poder materialmente limitado). En segundo lugar, en la división del propio poder constituido, organizado por la Constitución en un entramado de órganos a los que están asignados formas y ámbitos distintos de actuación. Al margen de que el entendimiento clásico de la división de poderes haya sufrido transformaciones, lo cierto es que el esquema básico de tal división distribuye en órganos diferentes las potestades de legislar, gobernar y juzgar, potestades que para estar respectivamente aseguradas (reservadas) han de incluir tanto elementos formales como materiales. De igual manera, ambos tipos de elementos deben darse en la división 
Este libro forma parte del acervo de la Biblioteca Jurídica Virtual del Instituto de Investigaciones Jurídicas de la UNAM

territorial del poder y, por lo mismo, en la correspondiente distribución territorial de competencias.

Poder dividido es, pues, poder limitado (formal y materialmente), pero las limitaciones sólo pueden ser efectivas si están garantizadas; esto es, si van acompañadas de los correspondientes instrumentos de control. No hay democracia sin limitación y no hay limitación sin control. De ahí que el control sea elemento inescindible de la democracia, o hablando en términos jurídicos, en cuanto que el Estado constitucional no es otra cosa que la democracia juridificada, que el control sea elemento inseparable del concepto de Constitución.

No es preciso que me extienda más sobre este asunto, cuyo tratamiento detallado he hecho en otros lugares, a los que me remito. ${ }^{24}$ Sólo pretendía enmarcar en estas reflexiones tan genéricas las consideraciones que a continuación se formulan.

\section{PARLAMENTARISMO Y PRESIDENCIALISMO, HOY}

\section{Aproximación y distanciamiento entre parlamentarismo y presidencialismo}

Es muy frecuente, en la actualidad, la opinión de que se está produciendo, como consecuencia de la democracia de partidos, una gran aproximación entre el parlamentarismo y el presidencialismo. Es difícil negarlo, pero es preciso aclarar que tal aproximación, que lo es más desde el punto de vista politológico que jurídico, no es un fenómeno completamente generalizado y convive en algunos casos, paradójicamente, con su opuesto; es decir, con un mayor distanciamiento entre uno y otro sistema, o en términos jurídicos, entre una y otra forma de gobierno. El problema no es nada simple y, por ello, conviene tratarlo con cierto detenimiento.

24 En especial, en Constitución y democracia, Madrid, Tecnos, 1989, y en Constitución y control del poder, Buenos Aires, Editorial Ciudad Argentina, 1995. 
Este libro forma parte del acervo de la Biblioteca Jurídica Virtual del Instituto de Investigaciones Jurídicas de la UNAM

Lo primero que cabe observar es la coexistencia, al menos en Europa, de dos movimientos contradictorios en relación con el presidencialismo. De un lado, de apreciación y emulación y, de otro, de crítica y rechazo. El primero es más reciente, creo, y tiene que ver con la extensión del fenómeno personalista en la política (acrecentado por el impacto televisivo-electoral, el liderazgo en el interior de los partidos, la pérdida de sustancia de los Parlamentos y la peculiar forma de gobierno de la Unión Europea). El segundo es más antiguo y tiene que ver con la polémica parlamentarismo-antiparlamentarismo en el periodo de entreguerras, pero aunque ha pasado tanto tiempo, aún perdura, conviviendo, como antes se dijo, con su opuesto y emergente.

\section{El rechazo europeo del presidencialismo}

No tiene sentido repetir aquí lo que aquella polémica, a que acaba de aludirse, entre parlamentarismo y presidencialismo significó en la teoría y en la práctica. ${ }^{25}$ Me referiré sólo a la identificación general de la democracia con el parlamentarismo en el pensamiento democrático europeo anterior a la Segunda Guerra Mundial.

El parlamentarismo como forma de Estado; esto es, como sinónimo de la democracia parlamentaria, la identificación era correcta, por supuesto, y ese fue, además, el sentido más profundo de la polémica, de manera que bajo el enfrentamiento parlamentarismo-antiparlamentarismo se encontraba realmente el enfrentamiento democracia-antidemocracia. Efectivamente, los enemigos del parlamentarismo o bien propugnaban directamente la dictadura (personal, de clase o de partido) o bien a veces (incluso sin desechar al mismo tiempo la pretensión anterior) apostaban por una forma de democracia "real" (frente a la "formal")

${ }^{25}$ Lo he tratado en otros trabajos, especialmente en "Parlamentarismo y antiparlamentarismo en Europa: sus repercusiones en España", en Las Cortes de Castilla y León 1188-1988, España, Cortes de Castilla y León, 1990, vol. II, pp. 387-405. 
Este libro forma parte del acervo de la Biblioteca Jurídica Virtual del Instituto de Investigaciones Jurídicas de la UNAM

en la que la libertad se disociaba teóricamente (y se erradicaba prácticamente) de la propia democracia, lo que venía a suponer, en verdad, no "otro" tipo de democracia, sino, sencillamente, su negación.

Sin embargo, el parlamentarismo como forma de gobierno (como una especie, pues, del género democracia parlamentaria) la identificación sería incorrecta, puesto que el régimen presidencialista puede ser tan democrático como el parlamentario. Precisamente por esto último resulta llamativo que en la polémica europea de entreguerras los defensores del parlamentarismo frente a la antidemocracia realicen esa defensa, casi sin excepciones, desde la exclusiva óptica del régimen parlamentario desentendiéndose de la solución presidencialista. Aunque podría acudirse a sobrados ejemplos de autores extranjeros, sobre todo alemanes o franceses, no hace falta irnos fuera para encontrar una muestra bien significativa de esa actitud política e intelectual: "Nosotros (diría Manuel Azaña) somos republicanos y todos, o la mayor parte, profundamente parlamentarios; pero yo, personalmente (si me es permitido hablar así) no soy más que parlamentario dentro de la República y no concibo una República que no lo fuese". ${ }^{26}$

Las razones de esa exclusión del presidencialismo y, por lo mismo, de la reducción de la democracia parlamentaria a la forma parlamentaria de gobierno son muy variadas. De una parte, las pasadas experiencias de gobiernos personales fuertes ("cesarismo" en el primero y segundo Imperio francés, jefaturas del Estado basadas en el "principio monárquico" en Alemania, entre otros ejemplos) habían creado en Europa un recelo comprensible ante cualquier forma de "presidencialismo". De otra parte, ese mismo recelo se veía acentuado por las experiencias contemporáneas del fascismo, las apelaciones formuladas por las doctrinas "regeneracionistas" cuando no puramente autoritarias a la eficacia de la acción de gobierno mediante la ocupación del poder por un "cirujano de hierro", un "hombre fuerte" o un "caudillo",

26 Obras completas, México, Oasis, 1966-1968, t. II, p. 704. 
Este libro forma parte del acervo de la Biblioteca Jurídica Virtual del Instituto de Investigaciones Jurídicas de la UNAM

situado por encima del Parlamento, o el recuerdo de alguna reciente dictadura militar (como en España).

A todo ello se sumaba una concepción europea de la democracia basada en la unidad de la representación política, esto es, en el monopolio parlamentario de la legitimidad popular, que admitía muy difícilmente una dualidad de representación capaz de operar independientemente en el Legislativo y en el Ejecutivo; y junto a ese impedimento teórico se encontraba un obstáculo de naturaleza práctica: la escasa tradición europea de un sistema de "equilibrios" entre poderes del Estado y entre poderes "políticos" y poderes "sociales" que es consustancial con la democracia norteamericana, como ya había señalado con sagacidad Tocqueville. No es de extrañar entonces la exclusión de la solución presidencialista en la III República francesa, en la República de Weimar o en la II República española, y la consiguiente identificación, por la teoría jurídica y política de la democracia, dominante en la Europa de aquel tiempo, entre democracia y forma parlamentaria de gobierno.

La coherencia de esta postura quedaba demostrada justamente por la actitud que se adoptaba en el campo contrario: la apuesta a favor del presidencialismo realizada desde el frente antiparlamentario no se basaba en la propuesta de un presidencialismo democrático, sino antidemocrático, esto es, dictatorial, como el propugnado en Alemania como remedio a la crisis del sistema de Weimar y teorizado, principalmente, por Carl Schmitt. Para unos (los defensores del parlamentarismo) y para otros (los afectos al antiparlamentarismo) estaba claro que la solución presidencial resultaba en Europa (a diferencia de lo que ocurría en los Estados Unidos de América) una solución poco conciliable con la democracia.

$\mathrm{Al}$ margen de esta equiparación, podría decirse que coyuntural y bien comprensible, entre democracia parlamentaria y forma parlamentaria de gobierno, la otra, y sustancial, equiparación entre la democracia y la democracia parlamentaria (esto es, entre la democracia y el parlamentarismo como forma de Estado) a la 
Este libro forma parte del acervo de la Biblioteca Jurídica Virtual del Instituto de Investigaciones Jurídicas de la UNAM

que nos referíamos al comienzo de este epígrafe, queda perfectamente expuesta en la certera afirmación de Kelsen: ${ }^{27}$

Aunque la democracia y el parlamentarismo no son términos idénticos, no cabe dudar en serio - puesto que la democracia directa no es posible en el Estado moderno - que el parlamentarismo es la única forma real en que puede plasmarse la idea de la democracia dentro de la realidad presente. Por ello, el fallo sobre el parlamentarismo es, a la vez, el fallo sobre la democracia.

Y así fue en el panorama europeo de aquellos años; donde triunfó el antiparlamentarismo se instaló la dictadura (de derechas o de izquierdas) y donde se conservó (o restauró) la democracia, ésta siguió observando su forma parlamentaria y, además, en el doble sentido: forma parlamentaria de Estado y forma parlamentaria de gobierno. Esta identificación europeo-occidental de la democracia con la forma parlamentaria de gobierno se prolongó en los años siguientes con la única excepción (al menos hasta los años setenta), relativa y que por ello tampoco se escapa totalmente de la regla general de la equiparación: el semipresidencialismo francés de la V República, que es, por supuesto, una democracia parlamentaria, pero que sólo posee algunos rasgos de la forma parlamentaria de gobierno. En los últimos decenios se sumaría también Portugal a esta solución semipresidencial.

\section{La emulación presidencialista en el parlamentarismo europeo}

Como antes se dijo, éste es un fenómeno reciente, que no tiene nada que ver con la tentación presidencialista-autoritaria (cuando no dictatorial) del periodo de entreguerras. Ahora no se trata de separarse de la democracia parlamentaria, sino de mantenerse en ella como forma de Estado, tampoco de abandonar la forma parlamentaria de gobierno instalando directamente un régimen presidencial, ni de extender el semipresidencialismo

27 Esencia y valor de la democracia, cit., p. 50. 
Este libro forma parte del acervo de la Biblioteca Jurídica Virtual del Instituto de Investigaciones Jurídicas de la UNAM

(que en otras latitudes se intenta, así, por ejemplo, en la última reforma constitucional argentina, pero que en Europa occidental sigue reducido como experiencia a los casos francés y portugués, sin que las polémicas surgidas en Italia en los últimos años hayan originado nada en la práctica). El supuesto al que nos estamos refiriendo es, sencillamente, el que se produce cuando se mantienen formalmente las estructuras de la forma parlamentaria de gobierno (aunque en algunos países con las reformas derivadas del llamado "parlamentarismo racionalizado"), pero se introduce una práctica política presidencialista, pasándose de un parlamentarismo de canciller o de primer ministro a lo que podría denominarse un parlamentarismo "presidencial".

Como consecuencia de una diversidad de factores, entre los que se cuentan la excesiva burocratización de los partidos, el aumento de la dimensión personalista en la política, el papel fundamental que en ella desempeñan los medios de comunicación de masas, el tipo de propaganda electoral que todo ello comporta, la multiplicación de las tareas del poder público (que siempre se traducen en un fortalecimiento del Poder Ejecutivo), e incluso (como más atrás ya se apuntó) la peculiar forma de gobierno de la Unión Europea (que otorga un protagonismo casi absoluto a los Poderes Ejecutivos nacionales), se ha ido generando en Europa una forma de gobierno que, sin transformación sustancial de las estructuras de la forma parlamentaria de gobierno, ha dejado en muy segundo plano a las cámaras y otorgado la primacía indiscutible no ya al gobierno, sino a la persona que lo dirige (canciller, primer ministro, presidente del consejo, presidente del gobierno, en sus distintas denominaciones).

Ahora bien ante esa "presidencialización" del régimen parlamentario cabe formular determinadas observaciones. ${ }^{28} \mathrm{La}$ primera está referida exclusivamente a los países con monarquía

28 Aragón, M., Gobierno y cortes, Madrid, Instituto de Estudios Económicos, 1993 y Solozábal Echeverría, J. J., "El régimen parlamentario y sus enemigos. (Reflexiones sobre el caso español)", Revista de Estudios Políticos, España, núm. 93, julio-septiembre, 1996. 
Este libro forma parte del acervo de la Biblioteca Jurídica Virtual del Instituto de Investigaciones Jurídicas de la UNAM

parlamentaria y consiste en poner de manifiesto la difícil compatibilidad entre el "presidencialismo" y la monarquía. Un primer ministro, o en el caso de España un presidente del gobierno, políticamente "separado" del Parlamento, apoyado en una legitimidad democrático-representativa propia (directa, originaria o, en fin, no derivada), convertido, pues, en el máximo "dirigente" del país, dejaría muy poco (por no decir ningún) espacio institucional al rey, que si bien en la monarquía parlamentaria no debe gozar de poder jurídico efectivo, sí que ha de tener preservado un ámbito de influencia para desplegar su necesaria función simbólica. En tal sentido, aunque aquella "separación" entre el presidente del gobierno y la cámara sea más de hecho que de derecho, no deja de ser perturbadora para la monarquía parlamentaria. Claro está que más perturbador aún, y enteramente criticable, sería el intento de fomentarla a través de normas jurídicas o de reglas políticas.

La segunda observación es de carácter más general y se refiere a la ambigua y deforme situación que se produce en esos supuestos de "presidencialización" del régimen parlamentario. Precisamente porque se trata de un "presidencialismo" encubierto, lo que suele suceder es que este híbrido reúne los defectos del presidencialismo y del parlamentarismo sin ninguna de sus virtudes. ${ }^{29}$ Así, la conexión (y no separación) entre Ejecutivo y Legislativo, propia del parlamentarismo, queda sin el contrapeso (también consustancial al régimen parlamentario) de una cámara capaz de servir de freno al gobierno; de otro lado, la legitimación popular directa del Ejecutivo y la autonomía política de su actuación, propias del presidencialismo, quedan sin el contrapeso (también consustancial al régimen presidencial) de la separación entre Ejecutivo y Legislativo.

29 Obviamente cuando hablamos de régimen parlamentario y de régimen presidencial nos referimos a sus modelos de correcto funcionamiento, no a sus desviaciones patológicas. Así, por no quedarnos sólo en modelos ideales, el régimen parlamentario puede estar bien representado por las monarquías parlamentarias europeas y el régimen presidencial por los Estados Unidos de América. 
Este libro forma parte del acervo de la Biblioteca Jurídica Virtual del Instituto de Investigaciones Jurídicas de la UNAM

En resumen, el híbrido a que nos estamos refiriendo tiende a convertirse en una forma de gobierno que descansa casi exclusivamente en el control electoral, pero no en el que resulta del equilibrio institucional, perdiéndose (o debilitándose) así el sistema de frenos y contrapesos en que se basa el Estado constitucional. Con lo cual se daría la paradoja de que en ese tipo de régimen parlamentario el Legislativo pueda ser más débil y el Ejecutivo más fuerte que en el régimen presidencial. El riesgo que para la libertad de los ciudadanos supone un sistema en el que no habría más separación de poderes que la garantizada por la independencia judicial no hace falta subrayarlo. Por lo demás, y aun admitiendo que esa independencia se encuentre objetiva y no sólo subjetivamente preservada, en cuanto que los jueces deben aplicar las leyes emanadas del Parlamento, realmente la preservación de la libertad quedaría casi exclusivamente reducida al ejercicio de la función de control de constitucionalidad de los actos del poder. Parece razonable entender que el Estado democrático no puede sostenerse mucho tiempo si descansa exclusivamente en la distinción, por muy básica e importante que sea, entre el poder constituyente y el poder constituido.

\section{LA NECESIDAD DE "PARLAMENTARIZAR" EL RÉGIMEN PARLAMENTARIO}

Si aceptamos, y la práctica no ha hecho más que confirmar esta afirmación de Kelsen, que la democracia no puede ser más que parlamentaria, parece claro que su suerte está ligada, entonces, a la del propio Parlamento, que es, sin duda, la pieza capital del sistema. El Parlamento constituye (o debe constituir) la institución central de la democracia como forma de Estado; es decir, del Estado constitucional democrático, sea su forma de gobierno parlamentaria o presidencial. Y ello es así, en primer lugar, porque la representación política tiene allí (en una cámara de composición plural) su más fiel expresión; en segundo lugar, porque el control político del Ejecutivo sólo en el Parlamento puede ejercerse de ma- 
Este libro forma parte del acervo de la Biblioteca Jurídica Virtual del Instituto de Investigaciones Jurídicas de la UNAM

nera permanente $\mathrm{u}$ ordinaria $\mathrm{y}$, en tercer y último lugar, porque únicamente a través de los debates parlamentarios pueden alcanzar suficiente legitimación democrática las decisiones del poder público (difíciles de predecir en el momento del voto popular y más difíciles aún de cubrir con el genérico y periódico mandato electoral).

En los Estados Unidos de América, ejemplo de país presidencialista, la fortaleza del Parlamento no la pone nadie en duda. Más aún, es razonable sostener que no puede haber un presidencialismo que funcione correctamente sin el contrapeso de un fuerte Parlamento. De ahí que hoy, por ejemplo, en algunos países iberoamericanos se esté planteando, después de la experiencia de presidencialismos problemáticos, la necesidad de "parlamentarizar" el sistema, no sólo para vigorizar la democracia, sino también para hacer funcionar correctamente al propio presidencialismo. Pues bien, algo muy parecido ocurre en el régimen parlamentario, que en muchos países ha experimentado un debilitamiento de las cámaras parlamentarias como consecuencia de los factores a que más atrás ya aludimos; es decir, como resultado del llamado "Estado de partidos". Sin partidos no hay democracia, ello es claro, y en ese sentido la democracia lo es "con partidos políticos", pero con igual claridad ha de decirse que eso es una cosa y otra bien distinta que el Estado (y la totalidad de la vida pública) sea patrimonio de los partidos. La defensa de la democracia incluye, sin duda, la defensa de los partidos, pero no puede dejar de ocultarse que un mal entendimiento del papel y el significado de éstos se han generado consecuencias muy nocivas para la democracia parlamentaria. Una de esas consecuencias, entre las más graves, es precisamente la atonía del Parlamento. ${ }^{30}$

Si el régimen presidencial no puede funcionar correctamente sin un Parlamento fuerte, mucho menos lo puede hacer, el régimen parlamentario. Por ello el fortalecimiento de las cámaras se presenta hoy como una de las necesidades primordiales de mu-

30 Garrorena, A., Representación política y Constitución democrática, Madrid, Civitas, 1991, pp. 57 y ss. 
Este libro forma parte del acervo de la Biblioteca Jurídica Virtual del Instituto de Investigaciones Jurídicas de la UNAM

chos países, entre ellos España, aquejados de esa atonía parlamentaria a la que acabamos de referirnos. Aquí, para vigorizar la democracia y para hacer funcionar con mayor corrección al propio sistema de gobierno, en lugar de "presidencializar" el parlamentarismo (ya suficientemente "racionalizado" por diversas técnicas constitucionales y por la disciplina de partido), lo que se necesita es "parlamentarizarlo". Hoy los medios de comunicación de masas y los tribunales de justicia están ocupando, en detrimento del Parlamento, el lugar central de la vida política. Y no precisamente por un exceso de aquéllos, sino por un defecto de éste. Es preciso, pues, que la vigorización del Parlamento haga posible que sea la prensa la que habitualmente trate de lo que se dice en el Parlamento en lugar de que, como ocurre ahora, sea el Parlamento el que habitualmente trata de lo que se dice en la prensa.

El fortalecimiento del Parlamento pasa por la adopción de diversas medidas normativas, entre ellas las relacionadas con el sistema electoral, la organización de las elecciones, la organización y financiación de los partidos y la organización y funcionamiento interno de las cámaras. También pasa por la adopción de determinadas reglas de conducta, que no normas jurídicas, por parte de los políticos, encaminadas a la dignificación institucional de la vida pública. Ni unas ni otras pueden ser objeto de examen, por obvias razones de espacio, en este capítulo. ${ }^{31} \mathrm{Sin}$ embargo, cualesquiera medidas encaminadas a fortalecer el Parlamento alcanzarían poco resultado si no se tiene claro el tipo de Parlamento que se puede tener, o mejor dicho, el cometido que hoy el Parlamento puede realizar.

Al Parlamento no puede pedírsele lo que el Parlamento, hoy, no puede dar. Por muchas razones, entre ellas las relacionadas con la internacionalización (y en España supranacionalización) de la política, sería imposible (y pernicioso) gobernar desde el Parla-

31 Para un tratamiento general acerca de los problemas actuales de los Parlamentos, la colección de trabajos recogida en Garrorena, A. (dir.), El Parlamento y sus transformaciones actuales, cit. 
Este libro forma parte del acervo de la Biblioteca Jurídica Virtual del Instituto de Investigaciones Jurídicas de la UNAM

mento. En la actualidad el gobierno de un país no puede dirigirse desde la cámara parlamentaria, de tal manera que el Ejecutivo no puede ser, de ningún modo, un comité delegado del Legislativo (lo que por otro lado, tampoco lo ha sido siempre en el pasado del "parlamentarismo clásico"). En el presente, complementariamente a la división de poderes o competencias jurídicas (legislar de un lado, reglamentar y ejecutar de otro), existe una división de funciones políticas entre Ejecutivo y Legislativo bastante clara: el gobierno dirige la política y el Parlamento la controla.

Es la función de control la que caracteriza (es decir, singulariza) al Parlamento. Función de control ligada a la consideración de la representación parlamentaria como representación plural, al entendimiento del Parlamento como institución y no sólo como órgano, en fin, a la concepción de la democracia como democracia pluralista. Ahora bien, si lo que puede y debe pedirse al Parlamento es que ejerza con la mayor plenitud posible la función de control, es preciso aclarar previamente lo que el propio control parlamentario significa, dada la diversidad de entendimientos que sobre ese término ha habido.

\section{EL SIGNIFICADO ACTUAL DEL CONTROL PARLAMENTARIO. \\ EL GONTROL PARLAMENTARIO EN SENTIDO AMPLIO. "COMPETENCIAS" DE CONTROL Y "DERECHOS" DE GONTROL}

En la doctrina española (y en la italiana) se mantuvieron en algún momento ciertas posiciones, que o bien identificaban el control parlamentario exclusivamente con la exigencia de responsabilidad política sosteniendo que sólo cabía hablar de control si éste iba acompañado de sanción (remoción del gobierno o derogación de la medida objeto del control), o bien separaban ambas categorías (control y responsabilidad) de manera tan absoluta que únicamente entendían por control la actividad de mera comprobación, desligada de la capacidad de sanción, con lo cual la exigencia de responsabilidad política (y su principal instrumento, la moción de censura) no sería 
Este libro forma parte del acervo de la Biblioteca Jurídica Virtual del Instituto de Investigaciones Jurídicas de la UNAM

actividad de control parlamentario. Sin embargo, en la actualidad, la generalidad de la doctrina, con algunas excepciones, ${ }^{32}$ acepta un concepto amplio de control parlamentario, entendido como toda actividad de crítica del gobierno con publicidad que en la cámara se realiza.

Las razones, teóricas y prácticas, que avalan este entendimiento amplio del control parlamentario son bastante concluyentes y no hace falta exponerlas aquí. Son suficientemente conocidas y, por lo demás, las he tratado extensamente en diversas publicaciones a las que me remito. ${ }^{33}$ Esa concepción amplia del control parlamentario es, claro está, la que permite entender que hay (como es cierto) control parlamentario en el régimen presidencial, o que en el Senado español (y en otras segundas cámaras donde no quepa la exigencia de responsabilidad política) puede haber actividad de control parlamentario, o que la actividad de información parlamentaria no puede desligarse de la actividad de control, o que, en fin, una cosa son los instrumentos y procedimientos específicos de control parlamentario y otra cosa la función de control parlamentario, que si bien se realiza particularmente a través de dichos instrumentos y procedimientos, no deja de poder realizarse también de manera general a través de todas las actividades de la cámara. En realidad es hoy la función de control la que más genuinamente caracteriza al Parlamento en cuanto que es también la más general y la más "propia" (el

32 Pues aún quedan representantes de la segunda posición antes aludida: así recientemente, López Guerra, L., "Control parlamentario y minorías", Anuario de Derecho Constitucional y Parlamentario, Madrid, núm. 8, 1996.

33 Entre otras, "El control parlamentario como control político", Revista de Derecho Político, núm. 23, 1986; Gobierno y cortes, cit.; "Información parlamentaria y función de control", en Instrumentos de información de las cámaras parlamentarias, Madrid, Centro de Estudios Constitucionales, 1994; Constitución y control del poder, cit. En dichos trabajos se cita doctrina extranjera y española que ahora no hace falta repetir, aunque sí debe destacarse en esta última, por su excelente defensa de la concepción amplia del control parlamentario, el artículo de Rubio Llorente, F., "El control parlamentario", Revista Parlamentaria de Habla Hispana, Madrid, núm. 1, 1985, recogido posteriormente en La forma del poder, Madrid, Centro de Estudios Constitucionales, 1993, pp. 241-258. 
Este libro forma parte del acervo de la Biblioteca Jurídica Virtual del Instituto de Investigaciones Jurídicas de la UNAM

Parlamento está sobre todo para "debatir", por ello, entre otras razones, sigue teniendo un significado crucial la reserva de ley pese a la fusión gobierno-mayoría parlamentaria ocasionada por la disciplina de partido). Justamente porque esa función de control tiene capacidad potencial para manifestarse en la totalidad de las actividades de las cámaras, es por lo que cabe hablar ${ }^{34}$ de una "polivalencia funcional" del control parlamentario.

Esa concepción amplia del control parlamentario es la que permite distinguir el control "por" el Parlamento del control "en" el Parlamento, ${ }^{35}$ siendo el primero el que puede realizar la cámara "como órgano" y por lo mismo expresando su voluntad por mayoría, y siendo el segundo el que pueden realizar, en la cámara "como institución", los parlamentarios individuales y los grupos parlamentarios. En el primer tipo hay, por supuesto, control, ya que sería absurdo sostener que si la crítica la realiza la mayoría de la cámara (situación improbable, pero no imposible, y no sólo en gobiernos de minoría), no convalidando una medida gubernamental o llegando incluso a derribar al gobierno, no se esté entonces en presencia de una actividad de control parlamentario (al contrario, la moción de censura debe considerarse como la máxima expresión del control parlamentario, lo que ocurre es que se trata de una expresión de difícil práctica en el parlamentarismo del presente).

En el segundo tipo (control "en" el Parlamento) hay también, por supuesto, control, aunque éste no lo realice la mayoría, sino la minoría. Y hay control porque hay capacidad de crítica, de información y de investigación y todo ello acompañado de debate con publicidad. El resultado del control no lleva aparejada la sanción

34 Por utilizar literalmente la misma expresión que ya formulé en "El control parlamentario como control político", cit.

35 Como vengo sosteniendo desde mi artículo "El control parlamentario como control político", cit., donde por vez primera utilicé esos términos que después parecen haber alcanzado cierta fortuna en la doctrina española. Se me deben perdonar las reiteradas autocitas, pero no tengo más remedio que acudir a ellas para excusarme de tratar con detenimiento esta materia y para evitar repetir ahora lo que ya he dicho en el pasado y con lo cual continúo de acuerdo. 
Este libro forma parte del acervo de la Biblioteca Jurídica Virtual del Instituto de Investigaciones Jurídicas de la UNAM

inmediata para el gobierno, por supuesto (que sólo la mayoría y nunca la minoría podría imponer como exigen las reglas de la democracia), pero puede ocasionar una sanción indirecta, una responsabilidad "difusa" (como dice algún sector de la doctrina italiana); esto es, convertirse en instrumento de presión, de fomento del control social del poder y de incitación a un futuro control electoral de los gobernantes. Los titulares de esta actividad de control son, pues, los parlamentarios individuales y sobre todo las minorías; es decir, generalmente en nuestras cámaras (aunque no exclusivamente, ya que puede establecerse un agrupamiento puramente numérico para ejercer determinada actividad de control, y ejemplos hay), los grupos parlamentarios.

Quizá lo que habría que plantearse es la necesidad de distinguir entre la "competencia" de control (como tal competencia sólo atribuible a órganos, y ejercitable entonces sólo como control "por" el Parlamento) y los "derechos" de control (no atribuibles a órganos, ya que no tienen derechos, sino a personas, esto es a los parlamentarios a título individual, o a agrupaciones de personas, esto es a las minorías, más comúnmente a los grupos parlamentarios, y ejercitables entonces como control "en" el Parlamento). E incluso cabría formular el elenco más básico de estos derechos de control como derechos a la "información", a la "investigación", al "debate" y al "tiempo", entendiendo por este último el "tiempo" en que deben tratarse los asuntos en la cámara, o más correctamente, al derecho a la celebración de debates y a la inclusión de puntos en el orden del día de las reuniones parlamentarias. ${ }^{36}$

36 Sobre este último derecho llamó la atención, con su sagacidad y ponderación habitual, el profesor Ángel Garrorena Morales en la reunión celebrada acerca de los instrumentos de información de las cámaras parlamentarias en el Centro de Estudios Constitucionales el 14 de marzo de 1994. Su intervención, recogida en el libro publicado al efecto por el propio Centro (Instrumentos de información de las cámaras parlamentarias, ya citado, pp. 143-148), constituye, pese a su brevedad, una de las aportaciones más lúcidas, junto con la de Francisco Rubio Llorente (El control parlamentario, ya citada) producidas entre nosotros acerca del control parlamentario. 
Este libro forma parte del acervo de la Biblioteca Jurídica Virtual del Instituto de Investigaciones Jurídicas de la UNAM

Tales derechos de control debieran garantizarse a las minorías e incluso algunos de ellos a los parlamentarios a título individual. Es probable, y razonable, que los derechos a la investigación y al tiempo (al "turno de asuntos actuales", por emplear la terminología del Bundestag alemán) sólo deban estar atribuidos a los grupos parlamentarios o a minorías numéricas, pero sería conveniente que los derechos de información y debate, al menos en algunas de sus facetas, también estén atribuidos a los parlamentarios a título individual (y no sólo el estricto derecho a formular preguntas, como ahora ocurre en nuestras cámaras).

Considerar como derechos estas capacidades de realizar el control "en" el Parlamento es, creo, una buena manera de dotar de agilidad y vigor a las cámaras; esto es, de acrecentar el papel y la legitimidad del Parlamento en los sistemas democráticos. ${ }^{37} \mathrm{Al}$ ser concebidos como derechos, gozarían de garantías frente a la mayoría, y por ello, al menos en Alemania y en España, pueden ser tutelados jurisdiccionalmente por el Tribunal Constitucional. Esta concepción sobrepasa, pues, en su generalidad y amplitud a la de mera identificación del control parlamentario con unos específicos procedimientos. Es cierto que respecto de ellos el control parlamentario como "derecho" viene a potenciarlos y a asegurarlos. Pero los derechos de control pueden también ejercitarse con ocasión de cualquier procedimiento (legislativo, de nombramiento o designación de personas, etcétera) de actuación de las cámaras.

En el fondo, la concepción amplia del control parlamentario está íntimamente unida a la consideración de las cámaras como lugares donde se expresa, como en ningún otro "espacio" del aparato estatal, el pluralismo político. El Parlamento es el único órgano estatal donde está representada la totalidad del pueblo y no sólo la mayoría, donde se concibe a la sociedad no como una unidad homogénea, sino como una unidad heterogénea, integrada por una variedad de ideales, posiciones e intereses que

37 Me remito para mayor desarrollo a mi trabajo, "Información parlamentaria y función de control", cit., pp. 13-35. 
Este libro forma parte del acervo de la Biblioteca Jurídica Virtual del Instituto de Investigaciones Jurídicas de la UNAM

deben ser representados y respetados. Y donde por ello ha de asegurarse, esto es, garantizarse jurídicamente a todas las "representaciones" parlamentarias del pluralismo político de la sociedad, el derecho (ejercitable en la cámara y con publicidad) a la expresión de sus ideas y programas, al debate, a información, a la investigación, a la crítica, en fin, de los gobernantes y de la totalidad de los asuntos públicos. Por todo ello, el Parlamento no es sólo un órgano, sino también una "institución" "38 y, por ello, tanto la teoría clásica de la personificación jurídica estatal (que sólo admite órganos dentro del Estado) como la teoría clásica de la democracia (que sólo admite, al modo "rousseauniano", una voluntad general homogénea, o más propiamente una representación general homogénea), son incapaces, por sí solas, de comprender el significado y las funciones actuales del Parlamento y por derivación del control parlamentario.

\section{LA RELACIÓN ACTUAL ENTRE LOS PODERES DEL ESTADO. PODERES POLÍTICOS Y PODER JURISDICGIONAL}

\section{Relaciones entre los jueces y el legislador}

Es cierto que la estructura de la división de poderes ha cambiado desde que se formuló en el siglo XVIII, el Estado constitucional del presente está organizado de manera mucho más compleja que en sus orígenes, claro está, además de que la "democracia de partidos" ha introducido modificaciones patentes en el sistema de la división del poder. Sin embargo, y como se dijo al comienzo mismo de este trabajo, pese a tales transformaciones lo que no puede admitirse es que la división de poderes haya desaparecido, ya que sin ella, sencillamente, no es posible el Estado constitucional. En la forma parlamentaria de gobierno, la relativización de la distinción entre Poder Legislativo y Poder Ejecutivo, que es una de las carac-

38 Ha sido Francisco Rubio Llorente el primero que llamó la atención sobre ello en su trabajo El control parlamentario, ya citado. 
Este libro forma parte del acervo de la Biblioteca Jurídica Virtual del Instituto de Investigaciones Jurídicas de la UNAM

terísticas propias de dicho régimen, no puede llegar al extremo de hacerla desaparecer, convirtiendo la división en confusión. De ahí la necesidad, más atrás ya aludida, de revitalizar el Parlamento y el control parlamentario. Y de ahí también la necesidad (requisito para lo anterior) de "reformular" el papel de los partidos en el Estado constitucional democrático.

De todos modos, de la división y relaciones entre los poderes "políticos" Ejecutivo y Legislativo (con las diferencias, que se mantienen, pese a ciertas aproximaciones, entre las formas parlamentaria y presidencial de gobierno) ya se ha tratado más atrás. Ahora, en la última parte de este capítulo, lo que pretendemos es referirnos a otra división: la que existe entre los poderes políticos, de un lado, y el poder jurisdiccional, de otro. Ahí, sí que ha de darse una separación neta entre ambos poderes (sea parlamentaria o presidencial la forma de gobierno), ya que en esa separación descansa la existencia misma del Estado constitucional en cuanto que éste es, sobre todo, Estado de derecho.

El problema más agudo que plantea hoy esa separación, no es el de la independencia judicial, que se encuentra garantizada (salvo situaciones patológicas) en todos los Estados constitucional-democráticos, sino el del equilibrio entre los poderes, que tiende a desnivelarse una veces a través de la introducción del juego de los partidos en el gobierno de la administración de justicia (en España hemos tenido algunos ejemplos acerca de ello en el funcionamiento del Consejo General del Poder Judicial) y, otras veces, a través de la judicialización de la política mediante el activismo judicial. Respecto de lo primero (la "politización" de la justicia), lo único que ahora podemos apuntar (por razones de espacio) es que probablemente el actual sistema español de designación de miembros del Consejo General del Poder Judicial no sea el más acertado; aunque, por otro lado, la elección parlamentaria de esos miembros no tiene por qué ser de peor condición (ni de inferior legitimidad, por supuesto) que la procedente de otros órganos del Estado. No es, pues, el elector, sino la forma de elegir la que quizá esté planteando entre nosotros 
Este libro forma parte del acervo de la Biblioteca Jurídica Virtual del Instituto de Investigaciones Jurídicas de la UNAM

problemas de desequilibrio entre el poder político y el poder jurisdiccional.

Mayor calado (desde luego teórico) tiene la otra fuente de desequilibrio institucional: la "judicialización" de la política. La consideración a todos los efectos de la Constitución como norma jurídica y la modificación del primitivo sistema kelseniano de justicia constitucional hacen que en varios países europeos, y entre ellos España, los jueces estén doblemente sometidos a la ley y a la Constitución, en cuanto que han de aplicar las dos conjuntamente. El establecimiento de la cuestión de inconstitucionalidad que, en principio, parecería que resuelve los problemas derivados de esa doble vinculación (que les impide inaplicar la ley pero que les obliga a no aplicarla si la consideran inconstitucional), no puede ocultar, sin embargo, las muchas complejidades teóricas y prácticas que ese modelo de la doble vinculación encierra.

Complejidades que se derivan de las peculiaridades mismas de la interpretación constitucional que es una tarea a realizar por todos los órganos jurisdiccionales (tanto de la jurisdicción constitucional propiamente dicha como de la jurisdicción ordinaria); de la difícil vinculación (por falta de instituciones precisas) de los jueces y tribunales ordinarios a la doctrina del Tribunal Constitucional no sólo cuando interpreta la Constitución, sino, sobre todo, cuando interpreta constitucionalmente la ley; y, en definitiva, de los problemas que origina un sistema como el nuestro, de vinculación de los jueces a la ley pero, al mismo tiempo, de aplicación por los jueces de un ordenamiento cuyos principios y valores, "constitucionalizados", han de ser integrados, a través de la práctica judicial, en la totalidad del sistema normativo infraconstitucional. No es este el lugar para extenderse en el tratamiento de tales problemas, ${ }^{39}$ pero sí, al menos, de llamar la atención sobre su existencia.

39 Sobre todo ello me remito a mi trabajo "El juez ordinario entre legalidad y constitucionalidad", Anuario de la Facultad de Derecho de la Universidad Autónoma de Madrid, Madrid, núm. 1, septiembre de 1997. 
Este libro forma parte del acervo de la Biblioteca Jurídica Virtual del Instituto de Investigaciones Jurídicas de la UNAM

\section{Relaciones entre los jueces y el gobierno}

La distinción entre poder político y poder jurisdiccional no puede estar referida únicamente, claro está, a las relaciones entre el Parlamento y los jueces, sino también a las que median entre los jueces y el gobierno. Es cierto que el Estado constitucional de derecho significa que todos los actos del poder han de estar sometidos a las normas y, en primer lugar, a la Constitución, lo que supone un sometimiento al control que ejercen órganos judiciales independientes. Por ello, el Estado de derecho es también, y necesariamente, Estado jurisdiccional de derecho. No hay inmunidades, pues, ni del legislador ni, claro está, de los gobernantes (ni tampoco, por supuesto, de los propios jueces). En consecuencia, el llamado, en terminología clásica, "Poder Ejecutivo" no puede estar exento del control judicial.

Ahora bien, admitir todo ello, dificil de negar en el plano de la teoría, ${ }^{40}$ no significa que se pase del "gobierno de las leyes" al "gobierno de los jueces", como a veces, con simpleza, se ha querido sostener por algunos. Tampoco, por supuesto, debe conducir a que se sustituya la "discrecionalidad" (que no arbitrariedad, claro está), constitucionalmente lícita, de ciertos actos del gobierno, por la "discrecionalidad", ilícita (en tales supuestos), de determinadas sentencias judiciales. El gobierno ha de ser controlado "jurídicamente", pero no "políticamente", por los jueces (aparte de que determinados actos y normas del gobierno no están sometidos al control de los jueces ordinarios sino del Tribunal Constitucional).

La defectuosa comprensión de esas relaciones entre gobierno y jueces está conduciendo, de manera casi inevitable, a la tan comentada "judicialización de la política", que acaba siendo también la "politización de la justicia". Ante esa situación los remedios no son fáciles de determinar, pero sí cabe al menos apuntar algunos, entre ellos el de la distinción, con todos sus efectos, entre

40 Véase por todos, García de Enterría, Eduardo, Democracia, jueces y control de la Administración, 2a. ed., Madrid, Civitas, 1996. 
Este libro forma parte del acervo de la Biblioteca Jurídica Virtual del Instituto de Investigaciones Jurídicas de la UNAM

controles políticos y controles judiciales, lo que significa que unos y otros no son sustituibles, de tal manera que ni la depuración de la responsabilidad política supone la desaparición de la responsabilidad jurídica ni, por el contrario, aquélla ha de quedar supeditada a la verificación de ésta.

En el fondo, como es bien sabido, el problema reside en que el Estado de derecho no puede suplir, con sus solos instrumentos, al Estado democrático. Por ello, la acumulación en los juzgados de la mayor parte de la labor de control de la actividad de los gobiernos, suele ser una consecuencia de la falta de agilidad o la falta de instrumentos del control político sobre dicha actividad, en especial, del control parlamentario. Sin que se produzca merma de los controles jurisdiccionales, puesto que el Estado lo es de derecho, es indispensable, al mismo tiempo, ya que el Estado lo es también (esa es su forma) de democracia parlamentaria, que se refuerze el control que las cámaras deben realizar. La división de poderes no consiste en el control de uno sobre los demás, sino en el control recíproco de todos ellos. 


\section{CAPÍtUlo TERCERO \\ FUENTES DEL DEREGHO PARLAMENTARIO}

\section{SOBRE EL CONCEPTO DE DERECHO PARLAMENTARIO}

1. Introducción. Algunas consideraciones previas respecto de las fuentes del derecho y la noción de ordenamiento en el complejo normativo regulador del Parlamento: ¿derecho parlamentario u ordenamiento parlamentario?

Como parece lógico, para referirse a las fuentes del derecho parlamentario es preciso, primero, determinar qué se entiende por éste. El concepto del derecho debe preceder al examen de sus fuentes, pues lo que éstas sean estará condicionado por lo que se estime que el derecho es. Así ocurre en el caso del derecho en general; es decir, del sistema jurídico, y también, claro está, de los derechos específicos o partes de ese sistema, aunque no de la misma manera. La diferencia, muy importante, consiste en que en el primer supuesto la concepción del derecho afecta a la misma concepción de las fuentes; esto es, a "qué" son las fuentes del derecho, mientras que en el segundo supuesto la concepción de un derecho específico (en nuestro caso el derecho parlamentario) sólo afecta a la simple determinación de "cuáles" de las fuentes (admitidas según el concepto general que del derecho se tenga) corresponden a ese sector. Lo que media entre las fuentes y el concepto del derecho, cuando observamos únicamente una rama o parcela de éste, no es una relación de cualidad sino de cantidad.

Por ello carece de sentido, en este capítulo sobre las fuentes del derecho parlamentario, plantearse lo que haya de entenderse por "fuente", que sólo cabe tratarlo a luz de la totalidad del de- 
Este libro forma parte del acervo de la Biblioteca Jurídica Virtual del Instituto de Investigaciones Jurídicas de la UNAM

recho o, en otras palabras, del ordenamiento jurídico o, más aún, del mismo derecho como "realidad". ${ }^{41}$ Sí parece conveniente, al menos, dejar constancia de ese concepto de fuente (unido a un concepto de derecho) del que se parte. Como es bien sabido, no se trata de un concepto pacífico, e incluso el mismo término "fuente del derecho" se ha considerado por algunos como científicamente inútil, entre otras razones por su plurivocidad. Quizá sería más correcto hablar de "normas" en lugar de "fuentes". No obstante, parece conveniente seguir utilizando el término "fuente del derecho" en cuanto que su uso es una convención muy generalizada, no es tan perturbador como algunos sostienen y además está reconocido por la Constitución (artículo 149.1.8) y el Código Civil (artículo 1o.), aparte de que resulta útil para diferenciar la prescripción (o el enunciado de una prescripción) jurídica de la norma misma, que siempre es producto de la interpretación. Compartimos la noción (común en un amplio sector de la doctrina) de que "son fuentes del derecho los actos y hechos a los que las normas sobre producción de un sistema jurídico concreto atribuyen la capacidad de crear normas con validez erga omnes" ${ }^{42}$

Alguna aclaración debe hacerse también respecto del uso, en este capítulo, de la expresión "derecho parlamentario" en lugar de

41 Es cierto, sin embargo, que hubo (y hay todavía) determinadas concepciones del derecho parlamentario que lo entienden como estricto "ordenamiento" diferenciado y que conducirían a tener que plantearse dentro de él "qué" son las fuentes de ese derecho (específicas y bien distintas de las fuentes generales). Parece, como se examinará más adelante, que se trata de concepciones inconciliables con el actual Estado de derecho y que, en consecuencia, el derecho parlamentario es sólo un sector del ordenamiento pero no un verdadero ordenamiento, lo que significa que no es ahí el lugar en que deba dilucidarse "qué" son las fuentes, sino "cuáles" son las fuentes que en tal sector operan.

42 Rubio Llorente, F., "Fuentes del derecho", en Enciclopedia furídica Básica Civitas, Madrid, Civitas, 1995, vol. II, p. 3169. En parecidos términos Pizzorusso, A., "Delle fonti del diritto (artículos 1o. al 9o.)", en Scialoja, A. y Branca, G. (dirs.), Commentario del Codice civile, 1977. Sobre el problema terminológico de las fuentes nos remitimos especialmente a De Otto, I., Derecho constitucional sistema de fuentes, 1987, pp. 69-75 y a Santa-María Pastor, J. A., Fundamentos de derecho administrativo, 1988, vol. I, pp. 286-288. 
Este libro forma parte del acervo de la Biblioteca Jurídica Virtual del Instituto de Investigaciones Jurídicas de la UNAM

"ordenamiento parlamentario" (en el bien entendido, por supuesto, de que el término "ordenamiento" significa ahí más exactamente "subordenamiento"; esto es, rama o sector del ordenamiento jurídico global, en nuestro caso del ordenamiento español). Es cierto que con el empleo del término "ordenamiento", para aludir a este sector normativo, cabría evitar alguna confusión derivada de la anfibología que caracteriza al término derecho (que puede significar tanto un sistema de normas cuanto un saber sobre ellas), pero esa es, posiblemente, la única (y parca) ventaja que aquel término proporcionaría, pues todo lo demás serían inconvenientes en el campo del derecho parlamentario. El riesgo de confusión se evita fácilmente, por otra parte, con aclarar, en el caso que así lo requiera (cuando se trata de fuentes ni siquiera hace falta tal aclaración), que se está utilizando la expresión derecho parlamentario como conjunto normativo y no como disciplina jurídica (aunque, como es lógico, una y otra dimensión se encuentren enlazadas y lo que sea el derecho parlamentario como saber jurídico esté condicionado, en variada medida, por lo que se entienda que es el derecho parlamentario como sector del ordenamiento).

Como se habrá observado, no se está rehuyendo, sin embargo, el empleo del término ordenamiento en un entendimiento equivalente al de sistema jurídico, lo que obliga a dar otra breve explicación. También, como en el caso de las "fuentes", el término "ordenamiento" es polémico e incluso puede ser perturbador para la ciencia del derecho, pero se utiliza aquí porque es un término generalmente aceptado y además porque está recogido en España no sólo en el texto de las leyes (Código Civil y Ley de la Jurisdicción Contencioso-Administrativa, principalmente), sino en el de la propia Constitución. Aunque, claro está, no entendiéndolo en el sentido acuñado por Santi Romano (que sería, aparte de científicamente inútil, contrario al mismo Estado de derecho que la Constitución establece), sino en el de equivalente a sistema normativo. ${ }^{43}$

43 Santamaría Pastor, J. A., op. cit., pp. 285-299. 
Este libro forma parte del acervo de la Biblioteca Jurídica Virtual del Instituto de Investigaciones Jurídicas de la UNAM

Ahora bien, si de lo que se trata no es de todo el derecho sino de un sector o rama del mismo, el término ordenamiento (o más propiamente subordenamiento) es más correcto utilizarlo respecto de conjuntos normativos derivados de la división territorial del poder, que respecto de los derivados de la división funcional del mismo. Cada ordenamiento autonómico, encabezado por su propio Estatuto de autonomía (y engarzado en el ordenamiento general del Estado a través de la Constitución), contiene la suficiente dosis de completitud (en cuanto que alberga las normas estatuyentes de la comunidad; es decir, reguladoras de su organización interna y atributivas de sus competencias), para manifestarse como un conjunto normativo autónomo y, por ello, perfectamente distinguible del ordenamiento general del Estado.

No ocurre ello con el conjunto normativo regulador del Parlamento. La norma estatuyente de las Cortes Generales es la propia Constitución que, además de regular su composición, también regula sus propias competencias y establece los principios y reglas principales de su funcionamiento. No hay, pues, un "ordenamiento parlamentario" con sustantividad propia (es decir, con la suficiente dosis de autonomía y de completitud) desgajado (diferenciado) de la Constitución. Las normas internas de las cámaras no suponen hoy más que una parte (complementaria y no principal, secundaria y no primaria, en el sentido estricto de estos términos) del conjunto normativo regulador de la institución parlamentaria. Tampoco podría hablarse, razonablemente, de un "ordenamiento parlamentario" encabezado por las normas constitucionales sobre la materia (directa e indirectamente aplicables) y completado por las normas internas de las cámaras y por las leyes que también pueden regular actividades que se realicen en aquéllas. La imposibilidad de aplicar entonces el criterio de la "autonomía" normativa (o si se quiere, de la "separabilidad"), haría extremadamente difícil (por no decir imposible) distinguir en tal caso el ordenamiento parlamentario del ordenamiento constitucional. En consecuencia, parece que el término derecho parlamentario resulta más apropiado que el de ordenamiento 
Este libro forma parte del acervo de la Biblioteca Jurídica Virtual del Instituto de Investigaciones Jurídicas de la UNAM

parlamentario para aprehender su significado y contenido, y por lo mismo para examinar cuáles sean sus fuentes. ${ }^{44}$

Hechas estas aclaraciones, procede ya, en desarrollo de las mismas, determinar, de manera más precisa, lo que se entiende por derecho parlamentario.

\section{Crítica a la concepción formal del derecho parlamentario}

La concepción formal del derecho parlamentario no coincide necesariamente con un entendimiento de éste como derecho estatutario; ya que un derecho así puede estar integrado tanto exclusivamente por normas especiales (distintas de las comunes) directamente producidas por la entidad (corporación, institución u órgano) de que se trate, cuanto por normas de naturaleza heterogénea y variada procedencia pero dirigidas a regular de manera singular (distinta de la común) a esa entidad (o a sus componentes). Es decir, la noción de derecho estatutario puede albergar tanto elementos formales como materiales e incluso sustentarse prevalentemente en unos u otros.

44 No tiene mucho sentido, probablemente, enumerar parte de la amplia (y bien conocida) bibliografía española y extranjera sobre las fuentes del derecho parlamentario (aunque la producción es menor, aparte de los correspondientes capítulos en los manuales o tratados, por lo que toca a las fuentes del derecho parlamentario en general que respecto de determinadas fuentes en particular; de todos modos, la mayor parte de los estudios sobre los reglamentos parlamentarios, que es donde se encuentra la producción más extensa, tratan también, por relación inevitable, de las demás fuentes). Basta con citar aquí una mínima selección de los trabajos que se han consultado. Así, nos han parecido de especial interés (por muy distintos motivos) los siguientes: en primer lugar el de Floridia, G. G., Il regolamento parlamentare nel sistema delle fonti, 1986; también, entre otros, los de Garrorena, A., "Derecho parlamentario", Enciclopedia Furídica Básica Civitas, cit., pp. 2345-2350; Martínez Elipe, L., "Las fuentes del derecho parlamentario", Varios Autores, Las Cortes Generales, España, Ministerio de Economía y Hacienda-Instituto de Estudios Fiscales, 1987, vol. III, pp. 1573-1631; Santaolalla, F., Derecho parlamentario español, España, Espasa Calpe, 1990, pp. 25-54; Punset, R., Las Cortes Generales, España, 1983, pp. 83-113; Manzella, A., Il parlamento, Italia, Il Mulino, 1991, pp. 15-56. 
Este libro forma parte del acervo de la Biblioteca Jurídica Virtual del Instituto de Investigaciones Jurídicas de la UNAM

Esta breve alusión al derecho parlamentario como derecho estatutario viene al caso en la medida en que algo de ello aparece en una de las más clásicas concepciones sostenidas acerca de aquel derecho; la que lo entiende como el orden jurídico emanado por la cámara en virtud de su autonomía y regulador, en exclusiva, del funcionamiento de la misma y del "estatus" de los parlamentarios. Se trata de una noción donde se mezclan elementos formales y materiales y que se aproxima a alguna de las viejas concepciones acerca del derecho administrativo, con la correspondiente negación de los controles externos y la única admisión del autocontrol, esto es, de una especie de jurisdicción retenida. Característica, esta última, derivada de la pretensión de "independencia" (que no sólo de simple autonomía) de la entidad en cuestión y, por ello (como consecuencia casi inevitable), de la configuración de su derecho "propio" más como un "orden" jurídico no enteramente positivizado (un "ordenamiento", quizá, en el sentido de Santi Romano) que como un sistema jurídico plenamente normativizado (un "ordenamiento" en el sentido que al término hoy debe dársele). Esta concepción resulta, como es lógico, difícilmente compatible con la consideración del Estado como persona jurídica y con el mismo principio del Estado constitucional de derecho. De ahí su abandono, hace ya tiempo, en la construcción conceptual del derecho administrativo. Menos abandonada ha sido, parece, en lo que se refiere al derecho parlamentario, aunque la impropiedad de su uso en esta materia sea casi tan patente como en aquélla.

La concepción formal del derecho parlamentario es, como antes se dijo, algo distinto de su consideración como derecho estatutario. Una y otra tienen evidentes proximidades, por supuesto, aunque también aparentes diferencias. La concepción formal no parte necesariamente de la nota de exclusividad (esto es, no toma como elemento básico la regulación en exclusiva de una materia) sin que sólo se sustente en las características singulares de las normas que integran el derecho parlamentario, que aparece así configurado como un derecho de emanación 
Este libro forma parte del acervo de la Biblioteca Jurídica Virtual del Instituto de Investigaciones Jurídicas de la UNAM

propia, integrado por normas producidas por la misma cámara sin intervención de otros poderes del Estado y dotadas de unas notas también muy especiales, entre ellas la flexibilidad (e incluso la disponibilidad, comprensiva tanto de la suspensión como de la derogación singular), la amplitud con que juega la costumbre y la no judicialidad.

Sin embargo, como ya se apuntó, las diferencias, en este caso (es decir, en el del derecho parlamentario), entre una y otra concepción ("estatutaria" y "formal") son más aparentes que reales, ya que en el fondo hay una coincidencia casi total en sus fundamentaciones (y en sus consecuencias prácticas), como se pone de manifiesto cuando se repara en los dos presupuestos en que se apoya la concepción formal: la independencia del Parlamento para producir y aplicar sus propias normas y la radical "politicidad" de todas las actuaciones que en el Parlamento se realizan.

La coherencia de la concepción formal con el sistema constitucional en que emerge (el del Reino Unido) e incluso con el sistema constitucional europeo-continental del siglo XIX (y parte del $\mathrm{XX}$ ) es patente, ya que tal sistema se asienta en la soberanía parlamentaria (en el caso británico y en el francés de la III República, o en la independencia organizativa interna de las cámaras en el caso de las monarquías constitucionales, ya fueran duales o de principio monárquico) y en el carácter exclusivamente político (o en todo caso no supralegal) de las normas ordenadoras del poder del Estado (es decir, de las normas constitucionales). Más aún, en dicha concepción formal las normas del derecho parlamentario, aunque cupiese diferenciarlas formalmente de la propia Constitución, habría que considerarlas, materialmente, normas constitucionales. En el fondo, la concepción puramente formal del derecho parlamentario se corresponde, casi inevitablemente, con una concepción puramente material de la Constitución.

Una concepción así (la que entendería el derecho parlamentario como un ordenamiento — "ordenamiento parlamentario"- dotado, consecuentemente, de un alto grado de autonomía y "separable" o netamente "distinguible" del ordenamiento 
Este libro forma parte del acervo de la Biblioteca Jurídica Virtual del Instituto de Investigaciones Jurídicas de la UNAM

general del Estado, cuestión a la que ya se ha aludido más atrás en esta ponencia), se enfrenta hoy con muchos problemas, todos derivados de su difícil compatibilidad con el Estado constitucional democrático y de derecho, más aún cuando, como ocurre en España, tal Estado tiene organizado, coherentemente, un sistema de control jurisdiccional de la constitucionalidad de los actos del poder. En este tipo de Estado no hay "soberanía parlamentaria" (ni plena independencia organizativa de las cámaras), ya que el Parlamento es un poder limitado (como los demás poderes del Estado) en cuanto que su actividad se encuentra regulada "efectivamente" (esto es, de manera jurisdiccionalmente controlable) por la Constitución. De donde se desprende que: a) las normas internas ya no son las únicas que regulan la actuación parlamentaria, puesto que, por encima de ellas, el Parlamento está regulado por la Constitución, e incluso también puede estarlo por la ley si existe al respecto una directa o indirecta previsión constitucional; b) el subordenamiento parlamentario (mejor dicho, el sector ordinamental parlamentario) ya no resulta separable del ordenamiento general del Estado, puesto que sus reglas principales e incluso sus principios generales se encuentran en la propia Constitución; c) los interna corporis acta, generales o singulares, han de ser susceptibles, por principio, de control de constitucionalidad (en nuestro caso ejercitado por el Tribunal Constitucional).

Esta ampliación de las fuentes normativas reduce, pues, el papel de la costumbre en el derecho parlamentario, limita fuertemente la flexibilidad aplicativa de éste y, por supuesto, la "disponibilidad" por la cámara de sus propias normas ${ }^{45}$ y, sobre todo, hace inviable la concepción formal para aprehender, desde ella, un sector del ordenamiento, puesto que los reglamentos parlamentarios (y la costumbre y los precedentes producidos por la propia cámara) sólo regularían por sí solos "parte" de la actividad

45 Los riesgos de disolución (de "pulverización" dice el autor al que nos vamos a referir) del derecho parlamentario derivados de la aceptación acrítica del principio de que "la Cámara es dueña de su propio reglamento", han sido bien señalados, entre otros, por Floridia, G. G., op. cit., pp. 228-233 y 513. 
Este libro forma parte del acervo de la Biblioteca Jurídica Virtual del Instituto de Investigaciones Jurídicas de la UNAM

de la cámara y del "estatus" de sus miembros; una parte, por lo demás, complementaria (o de desarrollo) y no básica, ya que las normas reguladoras de la composición de las cámaras y atributivas de sus competencias, las normas principales sobre su funcionamiento y sobre el "estatus" de los parlamentarios, así como los principios generales en la materia, no proceden del derecho interno parlamentario sino de la propia Constitución (e incluso de la ley). Una concepción puramente formal, como la aludida, significaría, pues, excluir del derecho parlamentario la regulación fundamental del mismo Parlamento. Entre nosotros no sólo ocurre que el derecho de producción interna de las cámaras no agota la totalidad del derecho parlamentario, sino también que no todas las normas de emanación exclusiva por las cámaras se integran en el derecho parlamentario, como es el caso, por ejemplo, del reglamento del Defensor del Pueblo, que emanado por las Mesas del Congreso y del Senado tiene como objeto un órgano que (aunque sea "alto comisionado de las Cortes Generales") no es en modo alguno órgano parlamentario.

De otro lado, ese derecho "propio", si bien disfrutaría de unas características "algo" distintas de las del resto del derecho (un poco de mayor flexibilidad, un poco de mayor juego de la costumbre), ya no se diferenciaría netamente de él. La única diferencia que subsiste en sentido estricto, como es la no judicialidad, se ha atenuado y relativizado bastante, en la medida en que, de un lado, los actos y disposiciones de las cámaras en materias de personal y administración son controlables por la jurisdicción ordinaria y, de otro, en el ámbito político parlamentario la no judicialidad ha de quedar reducida a aquellos interna corporis que no produzcan una vulneración de la Constitución. La especificidad procesal (en determinados países con jurisdicción constitucional concentrada y desde luego en España) consistente en que, a diferencia de lo que ocurre en el resto del derecho, las normas y actos (con excepción de los puramente administrativos) que emanan del Parlamento no sean fiscalizables por los órganos de la jurisdicción ordinaria sino por el órgano de la jurisdicción constitucional, no parece que suponga 
Este libro forma parte del acervo de la Biblioteca Jurídica Virtual del Instituto de Investigaciones Jurídicas de la UNAM

una distinción de "cualidad", es decir, de naturaleza jurídica, sino sólo de cantidad o de "grado".

\section{La concepción material del derecho parlamentario}

Una concepción exclusivamente material del derecho parlamentario, consistente en entenderlo compuesto por todas aquellas normas que disciplinan la composición, poderes y funcionamiento de las cámaras, así como el "estatus" de sus miembros, descartando cualquier consideración relativa a las singularidades de algunas de las normas que en ese sector del derecho se integran, sería hoy, probablemente, menos inapropiada que una consideración exclusivamente formal, pero no dejaría de ser también criticable. Y ello es así porque se han reducido las especificidades de las normas internas de las cámaras, pero no han desaparecido por entero y, en consecuencia, el derecho parlamentario sigue conservando algunas características que lo diferencian, incluso formalmente, de otros sectores del derecho. Lo que ocurre es que ese aspecto formal ya no es el principal elemento delimitador de tal sector, delimitación que hoy, razonablemente, sólo puede obtenerse a partir de una consideración material (lo que no impide que, complementariamente, hayan de tenerse en cuenta ingredientes formales).

Esa es también, al parecer, la concepción que subyace en este capítulo, en cuanto que al referirse a las fuentes del derecho parlamentario alude a "las fuentes supralegales", al "reglamento" (y a las "resoluciones normativas"), a la "ley" y a "otras fuentes". Ahora bien, respecto de la consideración material pueden sostenerse varios criterios de delimitación. Uno podría ser el de considerar que el derecho parlamentario está integrado por las normas que afectan exclusivamente al propio Parlamento. Esta concepción dejaría fuera del derecho parlamentario normas que tienen por destinatarios a otros órganos del Estado (al gobierno, principalmente, aunque también a algunos más), o a entidades del sector público o incluso a particulares, en sus actuaciones 
Este libro forma parte del acervo de la Biblioteca Jurídica Virtual del Instituto de Investigaciones Jurídicas de la UNAM

"en" o "ante" el Parlamento. No parece aceptable tal criterio, puesto que entonces el derecho parlamentario no regularía la total actividad de las cámaras.

Otro criterio delimitador sería el de considerar que integran el derecho parlamentario las normas reguladoras de la organización y actividad de las cámaras en el ejercicio de sus funciones supremas (es decir, de sus funciones políticas, o más exactamente, constitucionales). Escaparían así del ámbito del derecho parlamentario las normas reguladoras de las actividades puramente administrativas de las cámaras. Esta consideración podría ser congruente con la nota de no judicialización ordinaria del derecho parlamentario (aplicable y controlable sólo por el Tribunal Constitucional), puesto que no integrarían ese derecho normas aplicables y controlables por el orden jurisdiccional contenciosoadministrativo. También podría corresponderse con una noción "constitucionalista" (y no "administrativista") del derecho parlamentario como disciplina jurídica.

Tampoco parece aceptable una delimitación así, puesto que las actividades administrativas de las cámaras no pueden desligarse de su significado de órganos constitucionales dotados de autonomía, o dicho con otras palabras, puesto que tales actividades no dejan de tener "relevancia" política (o constitucional): sin autonomía administrativa se debilitaría, sin duda, la autonomía política de la cámara. Además, ya se dijo más atrás que resulta muy difícil (o mejor dicho, muy poco consistente) extraer de las diferencias entre la judicialización "ordinaria" y la judicialización "constitucional", criterios para establecer distinciones que afecten a la naturaleza de las normas o que sirvan para clasificar las ramas del derecho. Por otro lado, cualquier polémica sobre la ubicación intelectual (y no digamos académica) del derecho parlamentario como disciplina jurídica se presenta como un falso problema, en cuanto que se trataría de algo accesorio, con escasa significación "ordinamental". Se puede sostener, fundadamente, que el derecho parlamentario es parte del derecho constitucional, aunque algunas de las zonas de aquél pertenezcan también al 
Este libro forma parte del acervo de la Biblioteca Jurídica Virtual del Instituto de Investigaciones Jurídicas de la UNAM

derecho administrativo. De todos modos, sostener otro punto de vista sobre el "estatus" de aquella disciplina o defender la autonomía científica del derecho parlamentario puede ser tan aceptable como lo anterior, en la medida en que es tan irrelevante como lo anterior; es decir, en la medida en que ello no tiene consecuencias jurídicas de peso, entre otras razones porque la división del derecho en disciplinas jurídicas es sólo un asunto de cantidad o de grado (y muchas veces ni siquiera eso, sino sólo burocrático o docente) no de cualidad, ya que el derecho, desde el punto de vista científico, es sólo uno.

En definitiva, la concepción, amplia, que se comparte en esta ponencia es que el derecho parlamentario está integrado por todas las normas que regulan la organización y el funcionamiento de las cámaras (o más concretamente, la estructura, poderes y facultades del Parlamento, el "estatus" de sus miembros y la actividad que se realiza "por" las cámaras y "en" las cámaras); normas que son de variada jerarquía y diversa procedencia, algunas pertenecientes a tipos comunes o generales del ordenamiento (Constitución, leyes, jurisprudencia constitucional, costumbre, principios generales) y otras (las normas escritas de producción interna) específicas de esta rama del derecho y de singulares características en el sistema normativo. ${ }^{46}$

\section{LA DIVERSIDAD DE FUENTES DEL DERECHO}

PARLAMENTARIO

\section{Introducción: la transformación actual del derecho parlamentario}

Como es obvio, no se van a tratar en detalle cada una de las fuentes de ese derecho. Sí parece propio referirse a esas fuentes (salvo excepciones, la referencia se hará a las estatales, aunque las consideraciones sobre ellas son aplicables igualmente, en lo sustancial,

46 Singularidad comúnmente aceptada incluso por los que parten de una concepción material del derecho parlamentario, por ejemplo, Garrorena, A., op. cit. 
Este libro forma parte del acervo de la Biblioteca Jurídica Virtual del Instituto de Investigaciones Jurídicas de la UNAM

a las fuentes del derecho parlamentario autonómico) desde una consideración general; es decir, desde las transformaciones que el derecho parlamentario ha experimentado en el presente, o más exactamente, desde las exigencias que para ese derecho nuestra Constitución plantea. Una Constitución que es norma jurídica, o con mayor propiedad, derecho fundamental, provoca unos cambios en el entendimiento del derecho parlamentario que hacen difícilmente aceptables concepciones pretéritas o actuales fundadas en supuestos constitucionales bien distintos. Por otro lado, el modo en que nuestra Constitución regula el Parlamento genera consecuencias de evidente trascendencia para el resto de las fuentes que integran el derecho parlamentario.

\section{La constitucionalización del derecho parlamentario}

Las reglas y principios contenidos en las normas de la Constitución que afectan a las Cortes Generales, rigen en todo el sentido de la palabra, esto es, son normas jurídicas y, en consecuencia, aplicables; más aún, jurisdiccionalmente aplicables. Por el Tribunal Constitucional en el ejercicio del control de constitucionalidad de los reglamentos parlamentarios y de la tutela en amparo frente a decisiones (objeto claramente ampliado después de la STC 44/1995) o actos sin valor de ley de las cámaras (artículos 27.2 inciso $d$ y 42 de la Ley Orgánica del Tribunal Constitucional “[LOTC]). Y por los tribunales ordinarios en el ejercicio del control de legalidad y constitucionalidad de los actos y disposiciones de los órganos de gobierno de las cámaras en materia de personal y actos de administración (artículo 58.1 o. de la Ley Orgánica del Poder Judicial [LOPJ]). Lo mismo ocurre en el ámbito autonómico respecto de los principios constitucionales (que rigen para todas las organizaciones públicas) y los principios y reglas contenidas en los Estatutos de Autonomía que afectan a las asambleas legislativas (artículos 27.2 inciso $f$ y 42 de la LOTG y 74.1. inciso $c$ de la LOPJ). 
Este libro forma parte del acervo de la Biblioteca Jurídica Virtual del Instituto de Investigaciones Jurídicas de la UNAM

Las normas principales del derecho parlamentario se han constitucionalizado, no sólo porque se contengan (con amplitud) en la Constitución (y en los Estatutos de Autonomía), sino, sobre todo, porque tales normas constitucionales son jurisdiccionalmente aplicables. Esa es la gran diferencia frente al pasado y frente a otros países en los que la Constitución sigue siendo meramente una norma política (al menos en su pretensión de limitar al Parlamento). Las consecuencias de todo ello son de gran relieve. Por un lado, dicha constitucionalización, aparte de reducir la capacidad normadora del reglamento parlamentario e incluso de la propia ley, reduce también el campo de la costumbre en el derecho parlamentario, no sólo por la existencia de reglas constitucionales, sino, especialmente, porque los principios constitucionales (que son algo bien distinto de los principios generales aludidos en el artículo 1.4 del Código Civil (CG) y que por ello han de aplicarse con preferencia al derecho consuetudinario e incluso al derecho escrito infraconstitucional) se proyectan sobre una gran cantidad de materias propias del derecho parlamentario. Por otro lado, la constitucionalización convierte en fuente del derecho parlamentario a la jurisprudencia del Tribunal Constitucional, con todas las consecuencias que ello comporta. Respecto del derecho parlamentario autonómico, dicha constitucionalización, además de tener las consecuencias ya apuntadas, produce otro efecto: el de imponer una determinada "imagen" del Parlamento, derivada no sólo de los principios generales relativos a la democracia parlamentaria prevista en la Constitución, sino también de las reglas estructurales y funcionales relativas a las propias Cortes Generales (o aquí, más exactamente, al Congreso y al Senado), en cuanto que de sus rasgos básicos cabe extraer un modelo de cámara parlamentaria que ha de tener vigencia en todo el Estado español y que por lo mismo opera con eficacia (integradora o, al menos, indirecta o interpretativa) en el ámbito de los Parlamentos autonómicos.

Otra de las transformaciones que el derecho parlamentario experimenta por obra de su constitucionalización, y quizá la más 
Este libro forma parte del acervo de la Biblioteca Jurídica Virtual del Instituto de Investigaciones Jurídicas de la UNAM

obvia, es la que se deriva de la naturaleza jurídica de las normas constitucionales aplicables a las cámaras: la indisponibilidad de estas normas por el Parlamento y la consiguiente erradicación, en el ámbito de las mismas, de las mutaciones, normativas o consuetudinarias. Ni la norma en contrario (reglamentaria) ni el uso contrario pueden prevalecer sobre la letra de los preceptos constitucionales. Se reduce así, extraordinariamente, una de las características del derecho parlamentario clásico, como se reduce también, y consecuentemente, el ámbito de exclusividad del control interno de la cámara respecto de los actos parlamentarios (o de la no judicialidad de los interna corporis), ya que las infracciones del derecho parlamentario que constituyan al mismo tiempo infracciones de la Constitución han de ser externamente controlables. No caben (es decir, en términos estrictos, no adquieren validez) ni la costumbre o los precedentes contrarios a la Constitución ni las normas reglamentarias opuestas a ella (como es obvio en un ordenamiento en el que todas las normas, cualquiera que sea su forma, están subordinadas a la Constitución). Tampoco adquieren validez las suspensiones o derogaciones singulares del reglamento que constituyan infracción constitucional (aunque se adoptasen nemine contradicente). ${ }^{47}$

En el sentido antes indicado, y por poner un ejemplo, la conversión por los reglamentos del Congreso (artículo 79.1) y del Senado (artículo 93.1) en mayoría "simple" de la mayoría "de los miembros presentes", estipulada por el artículo 79.2 de la Constitución, sería rechazable por inconstitucional (y no sanable por el transcurso del tiempo) si supusiese (como algún autor ha sostenido) una verdadera mutación; sin embargo, es razonable sostener que los reglamentos del Congreso y del Senado han optado por una de las interpretaciones posibles del texto constitucional y que, por

47 La posibilidad de considerar como infracción constitucional la infracción (o la simple inaplicación) del reglamento parlamentario, ha aumentado bastante en cuanto que se ha admitido (razonablemente, por el Tribunal Constitucional) que el reglamento parlamentario es capaz de cubrir, respecto de los derechos de los miembros de las cámaras, la reserva de ley referida al artículo 23 de la CE. 
Este libro forma parte del acervo de la Biblioteca Jurídica Virtual del Instituto de Investigaciones Jurídicas de la UNAM

ello, la especificación de que la mayoría será "simple" no ha supuesto (pues las llamadas, por algunos, "mutaciones interpretativas" no son auténticas mutaciones) una vulneración constitucional.

En cambio, y siguiendo con los ejemplos, abiertamente criticable resulta el establecimiento (por el artículo 149.1. del reglamento del Congreso) de un límite temporal a la capacidad de avocación del Pleno respecto de la competencia legislativa delegada en las comisiones, cuando ocurre que el artículo 75.2 de la Constitución dice claramente que tal avocación podrá producirse "en cualquier momento" (como lo exige además el carácter delegado de esa competencia). Y lo mismo puede decirse respecto del establecimiento, por las Resoluciones de la Presidencia del Congreso del 16 de marzo de 1993 y de la Presidencia del Senado del 30 de septiembre de 1993, de un nuevo tipo de ley orgánica (a propósito de lo previsto en el artículo 47.3 del Estatuto de Autonomía del País Vasco), que, una vez aprobada por las Cortes Generales, requiere de posterior aprobación por el Parlamento vasco, contraviniéndose no sólo lo dispuesto en el artículo 91 de la Constitución, sino también los principios más generales conformadores de nuestro sistema de fuentes del derecho (cuando lo correcto hubiera sido calificar dicho texto no como ley orgánica, sino como iniciativa o proyecto de reforma estatutaria o, si se quiere, como proyecto de ley orgánica). En uno y otro caso, por la abierta inconstitucionalidad que suponen tanto las disposiciones de los reglamentos como las de las resoluciones de la Presidencia, no puede admitirse la figura de la mutación.

Si respecto de alguna materia puede hablarse, con propiedad, de reserva de Constitución, no cabe duda de que ésta sería la de las fuentes del derecho. Sólo la Constitución y los Estatutos de Autonomía, que desempeñan en cierto modo una "función constitucional", pueden crear tipos de leyes. De ahí la improcedencia de la regulación a que antes nos hemos referido, y de las regulaciones varias que existen en algunos reglamentos parlamentarios autonómicos, determinando tipos de leyes con mayorías especia- 
Este libro forma parte del acervo de la Biblioteca Jurídica Virtual del Instituto de Investigaciones Jurídicas de la UNAM

les para su aprobación (la crítica que aquí se está haciendo no se enerva por el hecho de que sea la propia norma estatutaria, como en el caso de Navarra, por ejemplo, la que habilite al reglamento para el ejercicio de esta potestad, puesto que aquí el reproche cabe trasladarlo a la propia norma estatutaria, el artículo 20.3 de la Ley Orgánica de Reintegración y Amejoramiento del Régimen Foral de Navarra LORARFNA, que atribuye al reglamento parlamentario lo que sólo la función constitucional del Estatuto puede cumplir: la determinación de tipos de leyes). La constitucionalización del sistema de fuentes (que es una característica básica del Estado constitucional, en el que, como se dijo hace ya mucho tiempo, "el Parlamento está para hacer leyes y no para hacer legisladores") y, por supuesto, la "constitucionalización" de nuestro derecho parlamentario no permiten operaciones de esa clase.

\section{El lugar de la ley en el derecho parlamentario}

A partir de un entendimiento material (y por ello amplio; es decir, comprensivo tanto de las fuentes inmediatas como de las mediatas) del derecho parlamentario, una de las primeras cuestiones que se suscitan acerca del lugar de la ley en dicho sector del ordenamiento, es el relativo a la atribución de competencias al mismo Parlamento. A diferencia de lo previsto para otros órganos constitucionales, respecto de los cuales la Constitución no agota la regulación de sus competencias, llamando también para ello a la LOTC (artículos 161.1. inciso $d$ y 165 Constitución Española, Consejo General del Poder Judicial, artículo 122.2 Constitución Española [CE]) o incluso a la ley ordinaria (gobierno, artículo 97 de la $\mathrm{CE}$ ); la atribución de competencias a las Cortes Generales parece quedar reservada exclusivamente a la norma constitucional (el tenor literal del artículo 66.2 de la CE es bien claro al respecto).

Sin embargo, la STG 108/1986 admitió (F.J. 12) que por ley (sin precisar si orgánica u ordinaria) pueden atribuirse otras 
Este libro forma parte del acervo de la Biblioteca Jurídica Virtual del Instituto de Investigaciones Jurídicas de la UNAM

competencias a las Cortes Generales no previstas específicamente en la Constitución. Esa doctrina del Tribunal Constitucional resulta en este punto criticable no tanto por el fondo de lo que intenta decir, sino por la forma en que lo expresa. Parece indudable que hay una reserva constitucional (claramente determinada en el artículo 66.2 de la CE y coherente con el significado y posición del Parlamento en nuestro sistema constitucional) en materia de "atribución" de competencias a las Cortes (y es posible sostener también que hay una reserva similar, aunque no expresada con la misma claridad, respecto del gobierno). Lo que ocurre es que el término "competencias" debiera entenderse como equivalente al de potestades o funciones, cuya atribución, en este caso, sólo es para la Constitución y no para la ley. Lo que puede hacer la ley es concretar, para las Cortes, "facultades" no expresadas en la Constitución, pero pertenecientes al ámbito de una "competencia" (o "potestad") constitucionalmente prevista. También puede la ley (y el reglamento de la cámara) efectuar el "desarrollo" (esto es, regular no la atribución sino el "funcionamiento" o "ejercicio") de competencias constitucionalmente previstas o de facultades legalmente expresadas. En tal sentido, y por poner un ejemplo bien significativo, las leyes orgánicas previstas en el artículo 93 de la Constitución no pueden sustraer potestades (o competencias en sentido fuerte) a las Cortes Generales, ya que sólo la Constitución, que puede atribuirlas, puede (mediante su reforma), detraerlas; pero pueden "delimitar" el "ejercicio de (las) competencias" por las Cortes, en cuanto que pueden traspasar (y así ha ocurrido en relación con la Unión Europea) facultades parlamentarias a organismos internacionales o supranacionales. De manera similar, y por lo que se refiere al gobierno, las leyes (y ese es el sentido que debe darse a la alusión contenida en el artículo 97 de la Constitución) pueden concretar, modular o delimitar potestades o competencias, o atribuir facultades, quizá, pero no realizar exactamente la atribución de tales potestades o competencias en el sentido ya aludido. 
Este libro forma parte del acervo de la Biblioteca Jurídica Virtual del Instituto de Investigaciones Jurídicas de la UNAM

De todos modos, el problema se complica en cuanto que el artículo 73.1 de la LOTG parece partir de que en el conflicto de atribuciones entre órganos constitucionales, las únicas normas capaces de servir de parámetro de control son la Constitución y las leyes orgánicas. Al margen de lo criticable que pueda ser tal precepto en ese punto, ${ }^{48}$ la interpretación que cabe darle es, probablemente: la distinción entre competencias en sentido estricto (o potestades) que sólo la Constitución (en el caso del Congreso y del Senado e incluso quizá en el del gobierno) y las leyes orgánicas (en el caso de otros órganos constitucionales) pueden atribuir, y facultades (o competencias en sentido lato) respecto de las cuales cabe su concreción por ley (e incluso por reglamento parlamentario). El título de atribución sólo estaría, pues, en las normas a que se refiere el artículo 73.1 de la LOTC, pero las demás normas que acaban de aludirse podrían integrarse en el parámetro de control de los conflictos (como se integran en el parámetro de constitucionalidad, para el control de constitucionalidad de las leyes, a determinados efectos, los reglamentos de las cámaras, pese a que ello no esté previsto en el capítulo I del título II de la LOTG).

Otro espacio que resulta confiado a la ley (y que no puede regular el reglamento parlamentario) es el relativo al establecimiento de derechos o deberes de los particulares (o de titulares de órganos públicos no incluidos en la esfera del Poder Ejecutivo) en relación con las cámaras (de ahí, por ejemplo, la regulación legal de las comparecencias ante las comisiones de investigación, donde la reserva de ley no sólo obedece a lo exigido por el artículo 76.2 CE, sino también a lo que establecen otras disposiciones constitucionales reguladoras de nuestro sistema de fuentes del derecho). Sobre este punto no deja de ser discutible la regulación por Decreto-ley (R.D-l. 5/1994, del 29 de abril) de la obligación de la administración tributaria y todo tipo de entidades financie-

48 Gómez Montoro, A. J., "El conflicto entre órganos constitucionales", Revista Española de Derecho Constitucional, España, año 13, núm. 39, septiembrediciembre 1993, pp. 277-294. 
Este libro forma parte del acervo de la Biblioteca Jurídica Virtual del Instituto de Investigaciones Jurídicas de la UNAM

ras de comunicar determinados datos a requerimiento de las comisiones parlamentarias de investigación. No parece nada claro que pueda ser materia de los decretos-ley regular potestades de las cámaras y establecer obligaciones de los particulares en relación con las mismas.

En cambio, distinto es el caso cuando se trata de actividad interna de las cámaras, que afecta exclusivamente a sus componentes o, todo lo más, al gobierno (entendido éste en sentido amplio, comprensivo de todas las organizaciones acerca de las cuales el gobierno tiene responsabilidad) en sus actividades parlamentarias. Por principio, esa materia parece formar parte de la reserva de reglamento parlamentario (más amplia que la compuesta por las remisiones constitucionales expresas), derivable del artículo 72.1 pero de construcción enteramente doctrinal. Sin embargo, tenemos ya bastantes casos de creación de comisiones parlamentarias (e incluso de regulación de su funcionamiento) por ley, posibilidad, además, que está reconocida expresamente por los artículos 46.2 del reglamento del Congreso y 49.2 y 57 del reglamento del Senado (y de la que existen precedentes en nuestro pasado y ejemplos actuales en otros ordenamientos).

Habida cuenta del significado de la reserva material reglamentaria y del procedimiento específico que la protege, cabría plantearse si el propio reglamento puede renunciar a ella ("desreglamentanto", por así decirlo, una materia a favor de la ley). El problema es distinto según se trate de una comisión cameral o bicameral. En el primer supuesto sería discutible (no procede hacerlo aquí) si la ley puede crearla, pero parece indiscutible que la ley no puede organizarla (ya que ese cometido sí que, en todo caso, habría de entenderse integrante de la reserva material reglamentaria): por ello la Ley 4/1980, del 10 de enero, de Estatuto de la Radio y la Televisión, se limita (artículo 26) a establecer una Comisión de Control en el Congreso de los Diputados, remitiendo su regulación al reglamento de la cámara. En el segundo supuesto (el de las comisiones bicamerales, así la Comisión Mixta Congreso-Senado para las relaciones con el Tribunal de Cuentas 
Este libro forma parte del acervo de la Biblioteca Jurídica Virtual del Instituto de Investigaciones Jurídicas de la UNAM

-Ley Orgánica 2/1982, del 12 de mayo-, la Comisión Mixta Congreso-Senado para las relaciones con el Defensor del Pueblo -Ley Orgánica 3/1981, del 6 de abril-, la Comisión Mixta Congreso-Senado para conocer el Plan Nacional de Investigación Científica y Desarrollo Tecnológico - Ley 13/1986, del 14 de abril - y la Comisión Mixta Congreso-Senado para la Unión Europea - Ley 8/1994, del 19 de mayo-), la procedencia de su creación, e incluso de su regulación por ley (aunque de hecho tal regulación legal no se haga de manera completa, ya que ésta suele ser desarrollada por normas aprobadas por las Mesas del Congreso y del Senado), pudiera tener una mayor fundamentación constitucional, pese a que sólo exista la previsión de creación legal de comisiones bicamerales en el reglamento del Senado (artículo 57).

Parece evidente que, en un sistema bicameral, el reglamento de una cámara no puede disponer sobre la otra. De ahí que hayan de ser decisiones bicamerales las que establezcan las comisiones mixtas de ambas cámaras. En tal sentido, podría pensarse que la ley (norma bicameral) también podría hacerlo. Es cierto, sin embargo, que igualmente (y con mejores títulos) podría hacerlo el reglamento de las Cortes Generales previsto en el artículo 72.2 de la Constitución, pues si bien ahí se le atribuye el cometido de regular las sesiones conjuntas de ambas cámaras, debe entenderse que ese es su contenido mínimo, pero no su contenido máximo, ya que, por principio, ha de ser capaz de regular cualquier materia (propia del reglamento parlamentario, claro está) que afecte conjuntamente al Congreso y al Senado (y así lo reconoce la Disposición Final 3o. del reglamento del Congreso). Mientras dicho reglamento no se dicte, podría pensarse que hay razones prácticas para fundamentar la entrada de la ley en la materia de que estamos tratando. De todos modos, no deja de ser ésta una cuestión opinable, puesto que la reserva de reglamento de las Cortes Generales va acompañada también de la garantía de un procedimiento específico (mayoría absoluta de cada cámara) y de mayor rigidez que el procedimiento legislativo (para que "no pueda hacerse por 
Este libro forma parte del acervo de la Biblioteca Jurídica Virtual del Instituto de Investigaciones Jurídicas de la UNAM

ley lo que deba hacerse por el reglamento"). Plantea pocos problemas, sin embargo, otro espacio que podría entenderse como "propio" de la ley (y previsto, lógicamente, en la propia Constitución) en el ámbito del derecho parlamentario: el complemento por reglas legales (legislación electoral), y sólo por ellas, de las normas constitucionales sobre la composición de las cámaras, el modo de elección de sus miembros, el régimen de sus inelegibilidades e incompatibilidades y la duración de su mandato. También se integran, sin especiales problemas, en el derecho parlamentario las leyes procesales sobre suplicatorios de parlamentarios, la propia ley presupuestaria e incluso las leyes de delegación, que pueden establecer "fórmulas adicionales de control" parlamentario sobre la actividad del gobierno en el ejercicio de la delegación legislativa (artículo 82.6 de la CE) ${ }^{49}$ Dicho todo esto, claro está, a título de ejemplo, sin agotar los casos de regulación por ley de actividad parlamentaria.

\section{Autonomía de las cámaras y derecho de producción interna}

La emanación por las cámaras de su propio derecho de organización sin intervención del Poder Ejecutivo siempre se había entendido como una muestra indudable de la autonomía parlamentaria. Hoy (en la forma parlamentaria de gobierno, y más específicamente en España, a cuyo ordenamiento esta ponencia

49 Todas estas leyes (y algunas más, pues la enumeración no ha sido exhaustiva) suscitan una reflexión de tipo general, que vamos a reducir al supuesto de las leyes electorales. La legislación electoral, además de integrarse en el derecho parlamentario (al menos determinadas reglas de aquella legislación), se integra también, como es obvio, en el derecho electoral (y toda ella es derecho constitucional, independientemente de que algunas de sus partes puedan pertenecer al derecho administrativo e incluso al derecho penal). Ello suministra un buen ejemplo de la imbricación entre los sectores del derecho, incluso de la interdisciplinariedad de los saberes jurídicos que es un dato inesquivable (y saludable) del presente, producido, entre otras causas, por las características de la Constitución del Estado social y democrático de derecho. Reiterando que resulta difícil, en tales circunstancias, sostener el carácter de genuino "ordenamiento" del derecho parlamentario. 
Este libro forma parte del acervo de la Biblioteca Jurídica Virtual del Instituto de Investigaciones Jurídicas de la UNAM

se refiere) no tiene, sin embargo, el mismo significado. La disciplina de partido y la correspondiente fusión gobierno-mayoría parlamentaria $^{50}$ relativizan aquella expresión de la autonomía. La producción de la costumbre parlamentaria queda, indudablemente, por activa o por pasiva, en manos de la mayoría, lo que significa, ordinariamente, en manos del gobierno. Las decisiones adoptadas por los órganos de gobierno de las cámaras en el ejercicio de esa especie de "jurisdicción retenida" que es el sistema de resolución interna de conflictos (con sus correspondientes vías de recurso), pueden funcionar como "precedentes" (y en ese sentido considerarse fuentes del derecho parlamentario) de manera análoga a como operan los precedentes judiciales, pero a nadie se le escapa que tales decisiones no pueden ser tomadas frente a la opinión de la mayoría parlamentaria (que en nuestro derecho tiene asegurada su prevalencia en los órganos parlamentarios bien a través del modo de composición de los mismos, bien a través del reconocimiento del voto ponderado), lo que equivale a decir frente a la opinión del gobierno.

Por otra parte, el hecho de que los mismos reglamentos parlamentarios no precisen de promulgación ni de sanción no significa tanto una garantía de autonomía política frente el Poder Ejecu-

50 Aunque puedan existir gobiernos de minoría, la regla básica del régimen parlamentario (no siempre puesta por escrito) exige que en esos casos el gobierno goce, si no del apoyo, sí al menos de la anuencia de la mayoría. La existencia de una mayoría parlamentaria expresa y abiertamente enfrentada con el gobierno en asuntos políticos primordiales hace imposible (si es que se quiere preservar el régimen parlamentario, claro está) la continuidad de aquél, ya que tal enfrentamiento significa, sin duda alguna, la ruptura de la relación de confianza. Por ello, adquiere escasa significación el hecho de que en los gobiernos de minoría (situación poco frecuente y, por otra parte, no muy en consonancia con nuestro sistema constitucional, que exige más bien gobiernos de mayoría, de un partido o de una coalición de partidos). Puedan generarse usos o establecerse precedentes en la actividad parlamentaria en contra de la opinión del gobierno. Mientras dure la relación de confianza, esas decisiones de la cámara contrarias al gobierno sólo podrán afectar (por lo que antes se dijo) a cuestiones no fundamentales de la vida parlamentaria. Aragón, M., Gobierno y cortes, Madrid, Instituto de Estudios Económicos, 1994, pp. 19 y 20. 
Este libro forma parte del acervo de la Biblioteca Jurídica Virtual del Instituto de Investigaciones Jurídicas de la UNAM

tivo (ya que hoy la sanción no incluye la potestad de veto y la promulgación es un acto debido) cuanto una expresión de autonomía jurídica, que en este caso es pura y exclusivamente formal. La verdadera garantía reside en la exigencia, para su aprobación, de una mayoría superior a la exigida para la aprobación de la ley. Sin embargo, tal garantía se encuentra hoy relativizada en la medida en que existen en nuestro ordenamiento una diversidad de leyes que precisan de igual mayoría reforzada que el reglamento parlamentario. Así, si el Parlamento español fuese unicameral no habría diferencia de fondo entre una ley orgánica y un reglamento parlamentario (como no la hay entre reglamento parlamentario autonómico y leyes autonómicas que precisan de mayoría absoluta para su aprobación, de las que existen sobrados ejemplos); en ambos casos, el procedimiento sería sustancialmente idéntico (en cuanto que sería igual la medida del consenso requerido para una y otra norma); no habría una reserva procedimental específica del reglamento frente a la ley orgánica (salvada la exclusión de la iniciativa gubernamental, que no alcanza mucha significación dada la relación entre el gobierno y la mayoría parlamentaria que le apoya), sino una exclusiva reserva material que por sí sola, sin el acompañamiento de una singular rigidez, significaría bien poco. Ahora bien, como en nuestro Estado el Parlamento es bicameral, puede pensarse, pues, que la reserva reglamentaria sí garantiza, al menos, la autonomía política del Senado (en cuanto que se exige en esa cámara una mayoría superior para la aprobación del reglamento que para la aprobación de una ley orgánica). De todos modos, cabría sostener que hoy, atenuada fuertemente la autonomía política del Parlamento respecto del Poder Ejecutivo, el principal sentido de la reserva de reglamento en un sistema bicameral es quizá el de asegurar la autonomía de una cámara frente a otra (dadas las peculiaridades de nuestro bicameralismo, en realidad lo que así se preserva es, sobre todo, la autonomía del Senado frente al Congreso).

No obstante, pese a la relativización actual de la autonomía política del Parlamento, la reserva de reglamento parlamentario 
Este libro forma parte del acervo de la Biblioteca Jurídica Virtual del Instituto de Investigaciones Jurídicas de la UNAM

sigue cumpliendo, como antes se dijo, un importante papel, lo que obliga a distinguir muy netamente el reglamento en sentido propio (aprobado por la mayoría absoluta de la cámara, y fruto de un procedimiento abierto a la intervención de la totalidad de sus componentes), de otras disposiciones internas que, integrándose también en el derecho parlamentario, no pueden equipararse exactamente al reglamento ni por el órgano emanador ni por el procedimiento de elaboración. Y no nos referimos sólo a las resoluciones de rango inferior al reglamento, e incluso al Estatuto de Personal de las Cortes Generales, sino a las normas supletorias o resoluciones generales interpretativas, sobre cuya naturaleza y rango se había producido una doctrina del Tribunal Constitucional escasamente matizada. De ahí la pertinencia del giro adoptado por la jurisprudencia constitucional en la reciente sentencia 44/1995, discutible en algunos extremos (por las contradicciones y confusiones que alberga y por no haberse atenido a lo dispuesto en el artículo 13 de la LOTG), pero introductora de ciertas distinciones que, a nuestro juicio, no era conveniente olvidar. 


\section{LA FUNGIÓN LEGISLATIVA DE LOS PARLAMENTOS Y SUS PROBLEMAS ACTUALES}

\section{SOBRE LAS DIFICULTADES DE DOTAR DE SIGNIFICADO A LA FUNGIÓN LEGISLATIVA}

Me parece que el primer problema teórico que hoy tiene la función legislativa es el de su propia definición. Si entendemos por función legislativa la actividad de producir leyes, entonces habrá de convenirse qué se entiende por "leyes" al objeto de encontrarle algún sentido a la función. Pero resulta que el concepto de ley, lejos de ser en la actualidad un concepto unívoco, ha adquirido tal grado de complejidad que lo convierte en elemento difícilmente capaz de caracterizar una determinada función. Como se sabe, hoy ya no es ley toda disposición normativa de carácter general. Es decir, la "generalidad" ya no singulariza exclusivamente a la ley. De ahí que, aun constatando el hecho de que en nuestro ordenamiento subsistan determinadas acepciones del término ley que la identifican, de manera lata, con norma jurídica, o, más exactamente, con norma de derecho escrito (como ocurre de modo más notorio, pero no, desde luego, de modo único, en el título preliminar del $\mathrm{CG}$ ) parezca indudable que el sentido estricto de ley no puede construirse ya solamente a partir de la noción de "generalidad", sino también de la noción de "rango" (puesto que la "generalidad" la comparte con el reglamento).

Ley y reglamento se presentan, pues, como dos "formas" de expresión del derecho objetivo, que se corresponden, además, con dos "potestades" distintas: la potestad legislativa y la potestad reglamentaria. Esta distinción, sin embargo, no resuelve por 
Este libro forma parte del acervo de la Biblioteca Jurídica Virtual del Instituto de Investigaciones Jurídicas de la UNAM

sí sola, como es obvio, los problemas del concepto de ley, aunque dejásemos de lado (que ya es dejar) la espinosa cuestión de las normas internas (o "reglamentos") de los órganos constitucionales distintos del gobierno. Y no los resuelve porque la distinción ley-reglamento sólo es posible construirla a través de un concepto de ley y no al revés; el reglamento se explica a partir de la ley y no la ley a partir del reglamento. Aparte de que la relación leyreglamento no es la única que cualifica el rango de la ley, sino que tal rango ha de comprenderse también mediante la relación ley-Constitución.

Ahora bien, prosiguiendo con la indagación a través del rango, ¿podría decirse entonces que la noción de ley cabe alcanzarla más correctamente concibiéndola como norma no ya supraordenada al reglamento, sino subordinada inmediatamente a la Constitución? Creo que ese camino tampoco nos conduciría a una solución aceptable. Y no sólo porque la distinta "cualidad" jurídica de la Constitución haga que la ley disfrute, respecto de aquélla, de un amplio margen de libertad, que ello no es obstáculo para comprender la idea de rango, sino porque muchas leyes no están inmediatamente subordinadas a la Constitución, de tal manera que la relación viene mediada por otras leyes, "intermedias", de las que tenemos una amplísima variedad en nuestro ordenamiento (leyes de bases, Estatutos de Autonomía, leyes del artículo 1501 y 2o. de la Constitución, "legislación básica" del artículo 149-1 donde, además, la "mediadora" puede ser a veces una norma reglamentaria, etcétera).

¿Se explicará más bien el rango de la ley por su específica resistencia frente al control? Es decir, porque las leyes sólo pueden ser anuladas por el Tribunal Constitucional, a diferencia de los reglamentos, que pueden serlo también por los órganos judiciales ordinarios. Esta condición, desde luego, es una característica de las leyes, ${ }^{51}$ pero no creo que sirva, por sí sola, para dotar de senti-

51 Aunque no sólo de las leyes, pues también las reformas de la Constitución (que, a mi juicio, no son exactamente "leyes") sólo pueden ser controladas por el Tribunal Constitucional. De todos modos, la posibilidad de que la jurisdic- 
Este libro forma parte del acervo de la Biblioteca Jurídica Virtual del Instituto de Investigaciones Jurídicas de la UNAM

do a la noción de ley, no ya por el hecho, obvio, de que existan leyes en sistemas jurídicos que carecen de Tribunal Constitucional, que ello sería un argumento rechazable, pues la noción de ley, en nuestro ordenamiento, ha de construirse, necesariamente, a partir de los datos que este ordenamiento (y no otros) proporciona, sino porque la característica antes aludida se predica de una gama tan compleja de normas (e incluso de actos) "con fuerza de ley", de un conjunto tan heterogéneo de "textos legales" que de poco sirve para comprender lo que de genuino o singular tenga la ley como fuente del derecho.

En consecuencia, creo que el rango, por sí mismo, no es criterio suficiente para entender el concepto de ley, o, en otras palabras, que la noción de ley precisa de otros elementos, además de los puramente formales, para su adecuada comprensión. De todos modos, este capítulo no es el lugar para entrar a fondo en un problema, el del concepto de ley, de tan extraordinaria magnitud y del que, por lo demás, se han ocupado con bastante rigor algunos de nuestros mejores juristas, ${ }^{52}$ lo que no excluye que, simplemente, me refiera a determinadas facetas del problema cuando así lo exija el desarrollo de esta exposición. Las consideraciones anteriores sólo pretenden poner de manifiesto que la actual complejidad de la noción de ley otorga un sentido también complejo y de difícil aprehensión al significado que pudiera atribuirse a la función legislativa concebida como la actividad de producir leyes.

ción ordinaria controle los decretos legislativos, no deja de introducir una seria complicación en el sistema y un necesario matiz en la afirmación que acaba de hacerse en el texto.

52 Garrorena, A., El lugar de la ley en la Constitución española, Madrid, Centro de Estudios Constitucionales, 1980; García de Enterría, E. y Fernández Rodríguez, T. R., Curso de derecho administrativo, Madrid, Civitas, 1983, vol. I, pp. 135277; Rubio Llorente, F., "Rango de ley, fuerza de ley, valor de ley", Revista de Administración Pública, España, vol. I, núm. 100 y 102, 1983; De Otto, I., Derecho constitucional. (Sistema de fuentes), Barcelona, Ariel, 1987, pp. 102-242; Gallego Anabitarte, A., Ley y reglamento en el derecho público occidental, Madrid, Instituto de Estudios Administrativos, 1971. 
Este libro forma parte del acervo de la Biblioteca Jurídica Virtual del Instituto de Investigaciones Jurídicas de la UNAM

¿Qué tipo de función sería ésta mediante la cual se producen normas tan dispares como Estatutos de Autonomía, demás leyes orgánicas, leyes ordinarias del Estado y de las comunidades autónomas, decretos-leyes, decretos legislativos del Estado y de las comunidades autónomas (sin que acaben ahí todos los tipos)? Todas esas normas son "leyes", esto es, ocupan el lugar de las leyes, o en otras palabras, tienen "fuerza de ley". ¿Cómo se definiría, pues, una función que ejercen muy distintos órganos (Parlamento y gobierno del Estado, Parlamentos y gobiernos de las comunidades autónomas) y empleando muy distintos procedimientos? Por lo pronto, ya no sería la función exclusiva de un poder del Estado: el Legislativo (aun concebido éste de manera plural: Legislativo estatal y Legislativos territoriales); sino una función que desempeñan varios poderes (cada uno de plural composición), Parlamentos y gobiernos. ${ }^{53}$ La función de "legislar" más que de un poder o de un órgano habrá de predicarse hoy, en consecuencia, del Estado en su conjunto (del Estado en su significación "global").

Una situación así, que es la actual, no viene, ni mucho menos, a "enterrar" (se entiende que definitivamente) a Montesquieu, que ello sería un modo muy simple de concebir la división de poderes, sino a mostrar que hoy esa división tiene poco que ver con la estricta "separación" (modelo tópico que, por lo demás, nunca ha existido de modo puro) y mucho con la "compartición", la "concurrencia" y la "cooperación" funcional, con los actos complejos, con los controles mutuos, con los frenos y contrapesos; en definitiva, con esa mezcla de división de poderes, forma mixta de gobierno y Constitución bien equilibrada que es el sistema que existe en los Estados democráticos de nuestro tiempo.

Cualquier indagación que hoy se haga acerca de la función legislativa y sus problemas ha de enmarcarse, pues, en esa con-

53 Y ello sin entrar en la cuestión de la jurisprudencia como fuente del derecho, y muy especialmente en el valor normativo (podría decirse igual "legislativo") de las sentencias del Tribunal Constitucional (o de la mayor parte de esas sentencias). 
Este libro forma parte del acervo de la Biblioteca Jurídica Virtual del Instituto de Investigaciones Jurídicas de la UNAM

sideración multiforme de la "legislación", de la que se deriva, cuanto menos, una desazonante perplejidad teórica: la dificultad de singularizar una función tan heterogénea, o de comprender, con las categorías clásicas del derecho público, una realidad tan distinta de la que existía cuando aquellas categorías fueron elaboradas. En los términos en que he venido planteando la cuestión hasta ahora es muy probable (o al menos a mí me lo parece) que ya ni siquiera tenga sentido (o sea correcto jurídicamente) sostener que existe hoy una "función" legislativa.

Ahora bien, constatada esa dificultad, el problema puede enfocarse de otra manera, como se evidencia en el mismo título de esta ponencia. No se trataría de indagar sobre la función legislativa "en general", sino sobre la función legislativa "del Parlamento" (o de los Parlamentos). Así reducida, la función tendría por objeto la producción no de cualquier tipo de norma con rango de ley, sino de "leyes" en sentido propio; esto es, de disposiciones legislativas parlamentarias, y la función la ejercería no una pluralidad de poderes, sino un único poder (aunque estuviese territorialmente diversificado o dividido a su vez): el Parlamento, es decir, el Poder "Legislativo".

Sin embargo, el mero enunciado de la cuestión en los nuevos términos que ahora acaban de utilizarse, ya pone de manifiesto que la reducción al propio ámbito parlamentario tampoco resuelve los problemas de conceptualización. Lo único que se consigue es distinguir las leyes (así "denominadas") de otras normas de idéntica fuerza, pero ni se facilitan elementos para saber lo que aquellas leyes sean ni tampoco, por lo mismo, para comprender lo que de singular tenga la función legislativa parlamentaria. Todo se queda en un juego de remisiones conceptuales recíprocas y, por ello, de tautologías. Es función legislativa del Parlamento la actividad que éste realiza de producir leyes. Son leyes las decisiones del Parlamento adoptadas en el ejercicio de su función legislativa. La legislación (entendida como función) es la tarea de hacer leyes. Las leyes son el producto de la legislación. En definitiva, función legislativa del Parlamento se identifica con un 
Este libro forma parte del acervo de la Biblioteca Jurídica Virtual del Instituto de Investigaciones Jurídicas de la UNAM

determinado procedimiento de actuación parlamentaria: el procedimiento legislativo.

Esta caracterización, únicamente "procedimental", de la ley no es, ni mucho menos, desechable y es posible que hoy sea una de las más seguras para entender lo que las leyes significan. Desde luego, resulta absolutamente necesaria para aprehender el concepto de ley (y sobre ello se volverá más adelante). Pero no basta por sí sola para dotar a la ley de sentido, por la misma razón de que para ello tampoco basta la exclusiva concepción "formal". ${ }^{54}$ Parece que la dimensión "procedimental" es capaz de singularizar una determinada actividad (la elaboración de las leyes), pero no ofrece todos los apoyos para valorarla y criticarla (es decir, para comprenderla), ya que nos daría cuenta de "cómo" se legisla pero no de "qué" se legisla; dejaría, en fin, al margen de la función aquello que en última instancia le presta sentido: su resultado, o si se quiere, su producto.

Y hoy, el producto de la actividad legislativa parlamentaria es ciertamente heterogéneo: leyes de "principios", leyes completas, leyes incompletas, leyes de detalle (leggine), leyes de bases, leyes de transferencias competenciales, leyes de habilitación, leyes "programa", leyes "marco", leyes "medida" (o leyes singulares), etcétera. Hoy ya no es tan clara la vigencia de la vieja frase de Locke de que el Parlamento está para hacer leyes y no para hacer legisladores; como tampoco es tan clara la vigencia de otros grandes postulados del derecho público, tales como los que afirmaban la "generalidad intrínseca" de la ley o la exigencia de que sólo mediante la ley pudiera regularse la libertad y la propiedad. ${ }^{55}$

54 No me parece oportuno extenderme aquí sobre los problemas que se derivan de la concepción formal de la ley, pero tampoco quiero dejar de apuntar las dificultades que hoy existen en nuestro ordenamiento (y en cualquier otro) para dotar a la ley de un sentido "material". Es posible que deban combinarse ambos enfoques, pero también es posible que hoy no nos valgan exactamente esas categorías entendidas en el sentido clásico en que fueron formuladas.

55 No voy a adentrarme ahora en el problema de la reserva de ley, pero me parece evidente que ahí está el quid de la cuestión. 
Este libro forma parte del acervo de la Biblioteca Jurídica Virtual del Instituto de Investigaciones Jurídicas de la UNAM

¿Ese producto tan variado de la actividad del legislador, o más exactamente, pues en ello estamos ahora, del legislador parlamentario, puede servir para prestar un sentido (unívoco) a una función, de tal manera que baste para comprenderla, esto es, que el producir "leyes" dote de significado a la función legislativa? Creo que no, en la situación actual, por la sencilla razón de que el producto mismo (la ley en sentido estricto o ley parlamentaria) carece de sentido unitario dada la evidente heterogeneidad "normativa" que puede albergar.

En tales condiciones parece que el primer problema teórico que hoy tiene la función legislativa es el de su propia definición. Pero ese problema teórico no es más que la consecuencia (a mi entender) de problemas existentes en la práctica, esto es, en la actividad que a través de la función legislativa se desarrolla. Cuando la teoría encuentra dificultades para comprender (o al menos formular conceptualmente) la realidad es porque, o bien los defectos están en la misma teoría, o bien la realidad es la defectuosa (y requiere de correcciones normativas), o bien (que suele ser lo más común) los defectos o las imperfecciones, o si se quiere los problemas, se dan en uno y otro plano (planos que no pueden rígidamente separarse en ningún sector del conocimiento y menos en el derecho, que es, sin duda alguna, un saber eminentemente práctico).

Dicho lo anterior, y ciñéndome a la función legislativa parlamentaria, intentaré, a continuación, señalar algunos de los problemas que hoy existen en los "productos" de esa función, algunos otros relativos al modo en que la función se ejerce; esto es, al procedimiento legislativo, para concluir con unas reflexiones finales y algunas propuestas de modificación o rectificación referidas tanto a la práctica como a la misma teoría. Todo ello con una advertencia, que quizá debiera haber formulado al principio, pero que aún estoy a tiempo de hacerla, en el sentido de que he de proporcionar un "panorama amplio" de la cuestión, con todo el riesgo de simplificación que ello comporta. 
Este libro forma parte del acervo de la Biblioteca Jurídica Virtual del Instituto de Investigaciones Jurídicas de la UNAM

\section{DIVERSIDAD DE TIPOS DE LEYES Y HETEROGENEIDAD}

\section{NORMATIVA DE SUS CONTENIDOS}

No creo que desvele ningún secreto si digo que el ordenamiento jurídico español es extraordinariamente complicado. Eso es un lugar común, y en este caso cierto. Estatutos de autonomía (con muy agudos problemas sobre su reserva y su rigidez), demás leyes orgánicas (cuya naturaleza, o mejor cuyo carácter, sigue estando sin aclarar por la doctrina y la jurisprudencia y cuya disfuncionalidad, al menos para mí, es patente), ${ }^{56}$ leyes de armonización, leyes de delegación del artículo 150-1 (me parece mejor término que el de leyes "marco"), leyes de bases del artículo 82, leyes ordinarias del Estado, "legislación básica" del artículo 149-1, decretosley, leyes ordinarias de las comunidades autónomas, leyes de bases o de delegación de las comunidades autónomas, decretos legislativos del Estado, decretos legislativos de las comunidades autónomas, reglamentos del gobierno del Estado, reglamentos de los gobiernos de las comunidades autónomas, normas reglamentarias de las entidades locales (algunas dotadas de reserva material, como ocurre en los "territorios históricos" vascos), legislación de desarrollo de las comunidades autónomas, de la "legislación básica" del Estado (que puede estar integrada no sólo por leyes sino también por reglamentos), de legislación de desarrollo de las comunidades autónomas, de "legislación" (aquí no básica) del Estado (posibilidad demostrada, y aceptada por el Tribunal Constitucional, en el caso de la Ley andaluza de reforma agraria); en fin, podría seguirse, pues la lista no es exhaustiva, y señalarse, además, la complicación añadida que comporta la introducción en España del derecho comunitario europeo.

Esta complejidad ordinamental no es sólo, ni mucho menos, la consecuencia obligada de la descentralización política terri-

56 Ya Garrorena, inteligentemente, denunció, desde el principio, los inconvenientes de la implantación de las leyes orgánicas en "Acerca de las leyes orgánicas y de su espuria naturaleza jurídica", Revista de Estudios Políticos, España, núm. 13, 1980; mismo autor, El lugar de la Ley..., cit., pp. 126-130. 
Este libro forma parte del acervo de la Biblioteca Jurídica Virtual del Instituto de Investigaciones Jurídicas de la UNAM

torial y de la incorporación a la Comunidad Europea. Ambos fenómenos habían de complicar nuestro ordenamiento, por supuesto, pero no hasta este punto, necesariamente. Han sido también las imprevisiones o las improvisaciones del Constituyente y la actitud poco reflexiva de los legisladores las que han adicionado aún más complejidad. Complejidad tanto más temible en cuanto que la cláusula de prevalencia está resultando inoperante, que la delimitación territorial de las competencias sigue estando excesivamente inconcreta y que la supletoriedad del derecho estatal se extiende a casi todos los sectores de la realidad objeto de las normas. ${ }^{57}$

De todos modos, la complejidad ordinamental es sólo una cara del problema. La otra reside en la diversidad de contenidos normativos de las mismas leyes. Junto a normas propiamente dichas; es decir, regulaciones generales, las leyes suelen contener a veces puros actos, esto es, decisiones concretas, o a veces también planes o programas, de escasa o nula condición imperativa. Y no digamos el caso, nada infrecuente, de las leyes "meramente didácticas", que no pretenden "ordenar", sino sólo "explicar". O ese otro caso de leyes completamente inútiles que intentan vincular al legislador futuro indicándole lo que debe o no debe hacer.

Ante este panorama, ¿puede decirse entonces que la palabra ley es una palabra vacía de contenido material, como decreto o como orden ministerial, en cuanto que se trata de una pura forma capaz de albergar los más diversos contenidos, esto es, capaz de contener una norma, un acto, un simple propósito, una definición teórica o, en fin, cualquier tipo de declaración o decisión que al legislador se le pueda ocurrir? ¿Puede decirse, pues, que hoy está completamente desdibujado el papel de la ley en el ordenamiento? Es posible que quizá pueda admitirse todo ello. Lo que me parece menos claro es que una situación así sea ente-

57 No se vea en esto una crítica al "gradualismo" y al "consenso" en la descentralización política del Estado, que me merecen la mejor opinión, sino una crítica a una falta de rigor técnico que no tiene por qué acompañar, obligadamente, a toda solución gradual o a toda solución adoptada por consenso. 
Este libro forma parte del acervo de la Biblioteca Jurídica Virtual del Instituto de Investigaciones Jurídicas de la UNAM

ramente nueva, presentándose como una especie de revolución frente a un sólido y pacífico concepto clásico de ley que ahora resulta totalmente dislocado.

Ni en el siglo XIX (que es donde solemos situar lo "clásico" en el derecho público) había un solo concepto de ley, ni las pretensiones sobre el papel de la ley del movimiento codificador llegaron plenamente a convertirse en realidad, ni las "mixtificaciones" actuales son un fenómeno nuevo, sino a veces bastante antiguo. La "fuerza de ley" es una categoría ya conocida en el derecho romano para predicarla de normas que, no siendo leyes, tienen un estatus similar a la lex (normas que "tienen fuerza de ley", esto es, legis habet vigorem, como se dice en las Instituciones de Justiniano, I, II, 4). También en el derecho romano la idea de generalidad no cualificaba exactamente a la ley, pues existían leyes de carácter personal que no pretendían reglar conductas futuras (leges... personales quae nec ad exemplum trahuntur).

La estricta correspondencia entre la división de poderes y la división de funciones, la diferenciación neta entre un Legislativo y un Ejecutivo fue el gran esfuerzo ilustrado encaminado a racionalizar el modo de producción de la voluntad estatal poniendo orden en la confusa situación precedente. Sin embargo, y por diversas causas que no viene al caso analizar aquí, la vieja complejidad volvió a resurgir (si es que alguna vez desapareció por completo, lo que resulta algo dudoso) y en nuestro siglo es evidente que el Ejecutivo legisla y el Legislativo administra. Lo primero, de todos modos, no plantea grandes problemas siempre que se salvaguarde la primacía parlamentaria y el legislador-gobierno sea un auxiliar y no un suplantador del legislador-Parlamento. Lo segundo, en cambio, origina (o puede originar) más graves perturbaciones, puesto que las "leyes singulares" están especialmente avocadas a producir discriminaciones individuales, o, si se quiere, y en términos más amplios, a provocar situaciones de inseguridad jurídica y de restricciones a la libertad. Este problema, la distinción entre ley y medida, distinción ya muy discutida en el primer Congreso de la Asociación Alemana de Profesores 
Este libro forma parte del acervo de la Biblioteca Jurídica Virtual del Instituto de Investigaciones Jurídicas de la UNAM

de Derecho Público celebrada en 1924 y sobre la que tanto se ha ocupado después la misma doctrina alemana posterior, ${ }^{58}$ constituye, sin duda, uno de los retos teóricos para el derecho público del Estado social de nuestro tiempo.

Ahora bien, señalar las complejidades que hoy se encierran en la "legislación" (en sus formas y en sus productos) no es añorar un modélico o racional "Estado legislativo" que, a mi juicio, nunca ha existido como paradigma, salvo en la ficción de Schmitt, que construía idealmente paradigmas o más bien caricaturas para después criticarlas como si fuesen reales. ${ }^{59}$ Lo que la complejidad pone de manifiesto, me parece, que son dos cosas: de un lado, los peligros que la complejidad encierra cuando es excesiva (puesto que la seguridad jurídica se asienta, entre otras razones, en el carácter sistemático y, por lo mismo, inteligible, predecible, del derecho) y, de otro, la imposibilidad, como antes ya apunté, de construir una noción exclusivamente material de la función legislativa parlamentaria. Quizá no sea enteramente cierto lo contrario: que la "legislación" es sólo un procedimiento; pero me parece cierto, en cambio, que hoy la legislación es, sobre todo, un determinado procedimiento.

\section{LEY, PARLAMENTO, PROCEDIMIENTO LEGISLATIVO Y PRINCIPIO DEMOCRÁTICO}

Comenzaré por establecer una premisa que, en términos generales, considero correcta: la doctrina europea del derecho público sigue siendo tributaria, en gran medida, del principio monárquico. Aún no se ha desprendido del todo de aquella magna construcción teórica urdida por la dogmática alemana en el siglo XIX. La soberanía del príncipe, y por derivación inmediata la soberanía del

58 Pueden destacarse, entre otros, los trabajos de Forsthoff, E., Über Massnahme-Gezetze, de 1955, y de Ballerstedt, K., Über wirtschaftliche Massnahme-Gezetze, de 1957.

59 Sofisma al que también se ha acudido mucho para "fundamentar" la "crisis" del Parlamento y de la representación. 
Este libro forma parte del acervo de la Biblioteca Jurídica Virtual del Instituto de Investigaciones Jurídicas de la UNAM

Estado, pero no la soberanía del pueblo, fue la piedra angular de aquella ingente elaboración jurídica, cuyas categorías principales arraigaron con tal fuerza que pervivieron, incluso, en la obra de quienes, ya en el siglo XX, se presentaron como abiertamente críticos y no como continuadores de aquellas doctrinas.

Es cierto que la técnica jurídica ha avanzado considerablemente gracias, en buena parte, a la teoría clásica del Estado y del derecho, pero la técnica no ha conseguido zafarse de la perspectiva desde la que fue elaborada, es decir, de las ideas pretéritas a cuyo servicio nació. De ese modo, el derecho público europeo padece una especie de dislocación conceptual, en el sentido de que gran parte de sus categorías básicas (las nociones mismas de soberanía, de legislación, de órganos o de derechos individuales, por poner sólo algunos ejemplos) guardan más coherencia con el principio monárquico alrededor del cual se construyeron, que con el principio democrático al que hoy deben servir. Se hace preciso, pues, recrear la teoría constitucional de nuestro tiempo para hacerla acorde con un concepto de Constitución radicalmente distinto del que imperó en la Europa del siglo XIX, al objeto de que el derecho constitucional (o, si se quiere, y más generalmente, el derecho público) se fundamente en la realidad del presente y no en la del pasado. Y esa realidad de ahora (realidad jurídica, se entiende) en el mundo, tópica aunque no exactamente, llamado occidental es la de la Constitución democrática.

El principio democrático debe jugar, en consecuencia, en el derecho público de nuestros días un papel equivalente a aquél que desempeñó el principio monárquico en el derecho público del siglo XIX. Para ello es preciso vencer la inercia de las viejas categorías, no con ánimo meramente iconoclasta (pues el derecho no deja de ser un saber acumulativo), sino con el propósito de establecer un cambio de "perspectiva", lo que significa abordar el problema en su misma raíz; esto es, extraer las consecuencias jurídicas pertinentes de la atribución al pueblo de la soberanía. De ahí que, en el fondo, la teoría constitucional de nuestro tiempo no pueda ser más que la teoría jurídica de la democracia. 
Este libro forma parte del acervo de la Biblioteca Jurídica Virtual del Instituto de Investigaciones Jurídicas de la UNAM

El principio democrático se presenta así como una pieza clave para reexaminar el concepto de ley. Principio que explica que la ley no es desarrollo de la Constitución y el que conduce a entender que la ley, si bien ya no es fuente primaria (que lo es la Constitución) debe seguir siendo, no obstante, la fuente "primordial" del ordenamiento, ${ }^{60}$ esto es, la norma de derecho que, bajo la Constitución, se ocupa de configurar, general e inmediatamente, las relaciones jurídicas en el seno de una sociedad. ${ }^{61}$ Esto no significa "relegar" a la Constitución, pero sí "revalorizar" a la ley como derecho de emanación democrática.

En este sentido, el viejo concepto de "reserva de ley", elaborado a partir del principio monárquico, precisa de una nueva fundamentación. La reserva de ley, en sentido estricto, esto es, de ley del Parlamento (frente a las disposiciones del gobierno con fuerza de ley y no sólo frente al reglamento), no puede entenderse hoy como un medio de asegurar al único poder representativo (el Parlamento) la normación de determinadas materias para hacerlas inmunes a la acción normadora del monarca (poder no representativo). Aquella construcción se basaba, pues, en la contraposición entre democracia (Parlamento) y autocracia (monarca), o, si se quiere, en la bipolaridad principio democrático-principio monárquico.

Hoy, como se decía, no puede ser ésta la sustentación teórica de la reserva, pues ni el monarca tiene poder normador ni el gobierno posee naturaleza autocrática, sino también representativa, ya sea directa en los regímenes presidencialistas o indirecta en los parlamentarios. ${ }^{62}$ En nuestro Estado constitucional es

60 Sobre una vigorosa defensa, constitucional, de la ley véase Díez-Picazo, L., "Constitución. Ley. Juez", Revista Española de Derecho Constitucional, España, núm. 15, 1985.

61 Aquí aparece nuevamente el problema de las leyes singulares ya antes señalado.

62 Lo que hoy se aprecia es, en realidad, un acercamiento entre la forma presidencial y la forma parlamentaria de gobierno en los Estados de democracia constitucional (que son, todos, de democracia parlamentaria). Subsisten, por supuesto, diferencias estructurales claras, pero, desde el punto 
Este libro forma parte del acervo de la Biblioteca Jurídica Virtual del Instituto de Investigaciones Jurídicas de la UNAM

cierto que los representantes directos de la voluntad popular son los parlamentarios y no el gobierno, pero no cabe negar que éste emana de la voluntad popular.

En esos términos, la reserva de ley tendría un débil fundamento si sólo se sostuviera en la contraposición órgano de representación popular directa (cortes)-órgano de representación popular indirecta (gobierno). Entendida la democracia como democracia pluralista, el Parlamento como órgano de representación de todo el pueblo y el gobierno sólo como órgano de representación de la mayoría, la reserva a la ley de determinadas materias no significa sólo la reserva al órgano más (directamente) democrático, sino también al órgano que, por contener la representación de la pluralidad de opciones políticas, permite que todas ellas (y no sólo la opción mayoritaria) participen en la elaboración de la norma. Esto es, significa, sobre todo, la reserva a un determinado tipo de procedimiento de emanación normativa (el procedimiento legislativo parlamentario) dotado de las características de contradicción, publicidad y libre deliberación que le son propias y que lo diferencian sustancialmente del procedimiento de elaboración normativa gubernamental. ${ }^{63}$

Es claro que la decisión final configuradora de la ley queda en manos de la mayoría parlamentaria, pero ello no priva de valor al hecho de que se garantiza a la minoría su derecho al debate, garantía jurídicamente relevante, hasta tal punto que es precisamente en el principio del pluralismo democrático donde me parece que debe anclarse hoy la teoría de los vicios sustanciales en el procedimiento legislativo.

de vista de la representación, la proximidad me parece evidente. No es este el lugar para extenderse sobre la cuestión, a la que ya he aludido también en mi trabajo "El control parlamentario como control político", Revista de Derecho Político, España, núm. 23, 1986, p. 34. Me remito a lo que expone (en la misma línea de interpretación) F. Rubio Llorente en su trabajo "El control parlamentario", Revista Parlamentaria de Habla Hispana, núm. 1, 1985, especialmente pp. 94-99.

63 En términos similares De Otto, I., Derecho Constitucional..., cit., pp. 152-154. 
Este libro forma parte del acervo de la Biblioteca Jurídica Virtual del Instituto de Investigaciones Jurídicas de la UNAM

\title{
IV. CONSIDERACIONES SOBRE EL PROCEDIMIENTO LEGISLATIVO
}

\begin{abstract}
Al margen de que puedan (y quizá deban) potenciarse los servicios técnicos de apoyo de los grupos parlamentarios para que presenten, en las mejores condiciones, las proposiciones de ley, lo cierto es que, por razones sobradamente conocidas, es el gobierno el que "dirige" el programa legislativo y a su iniciativa se deben (en los regímenes parlamentarios) la inmensa mayoría de las leyes. ${ }^{64}$ Por ello, resulta muy relevante esa etapa previa del procedimiento legislativo mediante el cual se prepara la iniciativa gubernamental, es decir, se elaboran los proyectos de ley. ${ }^{65}$
\end{abstract}

Curiosamente, una fase tan importante se encuentra en España casi huérfana de regulación. Los artículos 131 de la Constitución, 108 de la Ley Orgánica del Poder Judicial, 1o. de la Ley del Proceso Autonómico y algunos preceptos de las Leyes

64 La regla general es que hoy el mayor porcentaje de iniciativas legislativas las realiza el gobierno y no el Parlamento. De todos modos, esa regla no se cumple enteramente en Italia, donde son numerosísimas las iniciativas parlamentarias (en la primera legislatura se produjeron 1,375 iniciativas parlamentarias y 2,457 iniciativas gubernamentales; en la segunda legislatura 2,514 parlamentarias y 1,667 gubernamentales; en la tercera legislatura 3,686 parlamentarias y 1,569 gubernamentales; en la cuarta legislatura 3,576 parlamentarias y 1,442 gubernamentales). Ahora bien, lo que resulta más claro es el predominio absoluto no de las iniciativas gubernamentales, sino del número de leyes procedentes de la iniciativa gubernamental sobre el número procedente de la iniciativa parlamentaria (predominio rotundo incluso en la propia Italia como lo prueba el hecho de que en la primera legislatura, de las 2,318 leyes producidas, 2,054 procedían de la iniciativa del gobierno; en la segunda legislatura, de las 1,897 leyes producidas, 1,414 procedían de la iniciativa del gobierno; en la tercera legislatura, de las 1,796 leyes producidas, 1,300 procedían de la iniciativa del gobierno; en la cuarta legislatura, de las 1,478 leyes producidas, 1,058 procedían de la iniciativa del gobierno). En España, de marzo de 1979 al 15 de enero de 1986, se promulgaron 446 leyes que procedían de la iniciativa gubernamental y 83 que procedían de la iniciativa parlamentaria.

65 Fase a la que ha dedicado escasa (por no decir nula) atención la doctrina española. Por el contrario, en la doctrina italiana Bartoli, M. A., La formazione del progretto di legge, Milán, Giuffrè, 1983. 
Este libro forma parte del acervo de la Biblioteca Jurídica Virtual del Instituto de Investigaciones Jurídicas de la UNAM

de Procedimiento Administrativo y de Régimen Jurídico de la Administración del Estado disciplinan, de manera dispersa y asistemática, ciertos aspectos de esta cuestión. Ni hay ordenación acabada de la fase preparatoria ni esta fase es utilizada por el gobierno con el grado necesario de eficacia ${ }^{66}$ Esta situación contrasta con la de otros países, en los que la fase preparatoria adquiere un extraordinario relieve, no sólo por la depurada técnica empleada para preparar y "evaluar" el proyecto de ley, sino también por la amplia negociación con los sectores sociales afectados que en esa fase se desarrolla. El ejemplo más notable es quizá el de Suecia, ${ }^{67}$ donde, tanto la coordinación y el asesoramiento técnico en el seno de la administración, como los procesos de negociación con los grupos sociales se encuentran altamente institucionalizados en la fase preparatoria de la iniciativa legislativa gubernamental.

En cambio, la iniciativa legislativa, en sentido estricto, es decir, el acto de iniciativa, está configurado en nuestro ordenamiento de manera bastante adecuada, a mi juicio, en cuanto que sólo se atribuye al gobierno y a las cámaras, otorgándose a los parlamentarios, a las Asambleas legislativas de las comunidades autónomas y a una fracción del cuerpo electoral (iniciativa popular) no una auténtica iniciativa, sino una propuesta de iniciativa, fórmula que me parece coherente con el "parlamentarismo racionalizado" de nuestro tiempo y que resulta, en general, muy apropiada para evitar disfuncionalidades en la actividad legisladora de las cámaras. ${ }^{68}$

Por lo que se refiere a las demás fases del procedimiento legislativo parlamentario, y dada la imposibilidad de examinarlas aquí de manera completa, sólo voy a referirme a un problema

66 Aunque ahora, al parecer, existe una seria preocupación en algún sector del gobierno por la "legística".

67 Regner, G., "El procedimiento legislativo en Suecia", Revista Española de Derecho Constitucional, España, núm. 16, 1986, especialmente pp. 227-238.

68 En el capítulo siguiente desarrollaré un examen más detenido de la iniciativa legislativa. 
Este libro forma parte del acervo de la Biblioteca Jurídica Virtual del Instituto de Investigaciones Jurídicas de la UNAM

que estimo de cierta gravedad: el de la innecesaria duplicidad del procedimiento legislativo bicameral; esto es, el modo en que se configura en nuestro ordenamiento la intervención del Senado en la elaboración de las leyes. No creo que existan razones sólidas para defender la pertinencia de esta especie de proceso repetitorio que, de forma sustancialmente idéntica a la del Congreso, se celebra en el Senado, con la consiguiente complicación y el inevitable retraso en la elaboración de las leyes. La búsqueda de un papel definido para la cámara alta (papel del que ahora carece) debe pasar no sólo por potenciar sus funciones de cámara de representación territorial, sino también por replantearse con seriedad su participación en el proceso de elaboración de las leyes.

En cuanto a las modalidades del procedimiento legislativo, son varias, como se sabe, las respuestas que mediante esas modalidades pretenden darse a los problemas de lentitud y acumulación que son hoy casi un tópico cuando se habla de los males que aquejan a la función legislativa parlamentaria. El procedimiento de urgencia, con el consiguiente acortamiento de los plazos, o el más drástico de lectura única, son, entre otros, algunos de los remedios previstos para situaciones de especial necesidad, pero no son, en modo alguno, respuestas "ordinarias" a esos problemas, tan "ordinarios" también, de la lentitud y acumulación. La solución que en otros países, y en el nuestro, se ha ofrecido a este respecto es, sobre todo, la atribución de competencia legislativa plena a las comisiones.

En este punto, nuestra situación normativa no deja de ser criticable, por lo que después diré. Al objeto de que la cámara siga siendo un solo órgano y de que la potestad de hacer las leyes a ella en su conjunto (y no a divisiones internas de la cámara) esté atribuida, el otorgamiento de competencia legislativa a las comisiones se articula a través de la figura de la delegación. El pleno delega (no cede) a las Comisiones esa facultad. La CE (artículo 75-2) regula el supuesto de manera perfectamente coherente con dichas exigencias teóricas, que me parecen correctas: se trata de 
Este libro forma parte del acervo de la Biblioteca Jurídica Virtual del Instituto de Investigaciones Jurídicas de la UNAM

una delegación y, como tal, revocable en cualquier momento. El Reglamento del Senado (artículo 130) respeta escrupulosamente esa disposición constitucional. Sin embargo, el reglamento del Congreso (artículos 148 y 149) vulnera abiertamente lo previsto en la Constitución convirtiendo la delegación en una auténtica cesión. Y así establece una presunción general de delegación muy poco ortodoxa con los requisitos propios de la delegación, figura que exige más bien delegaciones expresas y caso por caso, que delegaciones presuntas y generales. Pero lo más criticable no es eso (con ser ya grave), sino la limitación que se fija para el Pleno en su capacidad de revocar, en cuanto que sólo se permite la avocación (cuando no hubiese sido "prevista" por acuerdo adoptado en el debate de totalidad o en la toma en consideración) antes de iniciarse el debate en comisión. Pasado ese momento, pues, la delegación es irrevocable; es decir, no hay delegación, sino transferencia, en abierta contradicción con lo que la teoría demanda y la Constitución exige.

Las medidas para agilizar la tramitación parlamentaria de las leyes son loables, siempre que no incurran en infracciones constitucionales de este calibre, aparte de que no se entienden los efectos beneficiosos que para la práctica pueda reportar un sistema como el previsto en el reglamento del Congreso. Como tampoco se entiende, dicho sea de paso, que la fórmula de las "leyes de Comisión" se haya extendido a diversos Parlamentos de las comunidades autónomas (como se prevé en los Estatutos de Cataluña, Andalucía, Valencia y Baleares), donde la menor densidad de la tarea legislativa y la composición menos numerosa de los Plenos no hacen tan necesario (a diferencia de lo que ocurre en las Cortes Generales) acudir a esta solución. Es posible que la previsión normativa, en estos casos, no sea, en sí misma, criticable, pero sería conveniente que no se utilizase en la práctica con asiduidad, entre otras cosas porque, a mi juicio, el arraigo de los Parlamentos regionales se compadece mal con la desvalorización de sus sesiones plenarias. 
Este libro forma parte del acervo de la Biblioteca Jurídica Virtual del Instituto de Investigaciones Jurídicas de la UNAM

\section{AGERGA DE ALGUNAS PROPUESTAS DE REFORMA}

Pese a los defensores de la deregulation o a los denostadores del Estado social (cuya "liberalización" comportaría, quizá y en todo caso, menos administración, pero no creo que menos leyes), parece cierto que el Estado de nuestro tiempo impone una gran actividad legislativa: muchas leyes que, además, se cambian constantemente y que, en gran parte, poseen un contenido técnico muy complejo. Esos son los datos que se derivan de la realidad; es decir, de la amplísima normativización (difícilmente reversible) de la vida social y económica y del carácter fuertemente dinámico de ésta.

Para que la función legislativa haga frente, con éxito, a esa realidad (tan distinta de la del Estado constitucional de otras épocas), suelen defenderse, a veces, en el Estado democrático (que es en exclusiva, como es obvio, al que me estoy refiriendo) dos tipos de soluciones, que podrían calificarse de radicales o extremas. La primera consistiría en la máxima potenciación posible de la actividad legisladora del Parlamento, con la disminución, también máxima posible, de la actividad "legisladora" del gobierno. Se trataría de equipar técnicamente al Parlamento de tal manera que pudiese competir con la burocracia de la administración para hacer "buenas" leyes y de agilizar de tal manera el procedimiento legislativo parlamentario (acortamiento de los plazos, leyes de lectura única, limitación de las enmiendas, conversión de las comisiones en legisladores habituales, etcétera) que hiciera posible la emanación del mayor número de leyes en el menor espacio de tiempo, al objeto de limitar drásticamente la delegación legislativa a favor del gobierno.

La segunda solución sería la opuesta, admitir que el Parlamento no puede competir (por muchos expertos que lo auxilien) con el gobierno desde el punto de vista técnico, ni subvenir (por mucho que se agilice el procedimiento legislativo) a la necesidad de emanar tantas leyes como se requieren; en consecuencia, de lo que se trataría es de potenciar las delegaciones legislativas a favor del gobierno y de reducir la actividad legisladora parlamentaria 
Este libro forma parte del acervo de la Biblioteca Jurídica Virtual del Instituto de Investigaciones Jurídicas de la UNAM

al máximo, ocupándose sólo de las "grandes leyes", esto es, de las que contengan las decisiones políticas más fundamentales.

Como puede observarse, ambas soluciones descansan en un entendimiento muy distinto del significado del Parlamento y de la ley. La primera sería fiel a la vieja concepción del Parlamento como único poder representativo frente a un gobierno desprovisto de legitimidad popular (en el fondo la clásica idea monista) y, por ello, se postula que no debe haber más "ley" que la ley parlamentaria. La segunda se correspondería, más bien, con la aceptación de que hoy también el gobierno es representativo, incluso (para algunos) más representativo que el Parlamento (democracia plebiscitaria, liderazgo del primer ministro, "presidencialismo parlamentario", dominio del gobierno sobre el Parlamento, etcétera); sería una nueva versión del "dualismo" clásico y, en consecuencia, abogaría por la no identificación entre "ley" y ley parlamentaria; la tarea "normadora" estaría hoy, en su casi totalidad, en manos del gobierno; hoy no sería, pues, la función legislativa la característica del Parlamento, sino la función de control; incluso la "legislación" comunitaria europea (que no es producida por el Parlamento, sino por el "Ejecutivo", que es allí el verdadero "legislador") proporcionaría un apoyo práctico notorio a esta concepción teórica.

A mi juicio, las dos soluciones extremas a las que acabo de referirme resultan sumamente criticables. La primera por irreal y contradictoria. Irreal, porque, efectivamente, por mucho que se tecnifique y agilice la función legislativa del Parlamento no podrá competir con la ingente burocracia gubernamental ni hacer frente a las amplísimas necesidades de normación del Estado de nuestros días. Irreal también, porque hoy, sin duda alguna, el gobierno, y no sólo el Parlamento, es representativo. Contradictoria, porque la excesiva agilización del procedimiento legislativo parlamentario iría en detrimento del principio democrático pluralista, principio que exige la amplitud de la discusión y del debate público parlamentario y principio que es hoy la más sólida fundamentación del concepto de ley. 
Este libro forma parte del acervo de la Biblioteca Jurídica Virtual del Instituto de Investigaciones Jurídicas de la UNAM

La segunda solución sería criticable por su escasa o nula conciliación con el significado del Parlamento y de la ley en el Estado constitucional democrático. Es cierto que el gobierno también es representativo, pero esa representación resulta de muy distinta cualidad que la del Parlamento. Y no se trata sólo de que una representación sea directa y otra indirecta (que eso no es lo principal, aparte de que ambas son directas en el régimen presidencial), sino de que el Parlamento representa a todo el pueblo y el gobierno sólo a la mayoría. Por ello, ha de quedar reservada a la ley parlamentaria la regulación de determinadas materias (y no sólo de las grandes decisiones), así pues no debe haber (a la inversa) materias reservadas al reglamento, por lo que, la función legislativa, y no sólo la de control, sigue siendo una función primordial del Parlamento, y, por ende, en definitiva, la función legislativa es también, al mismo tiempo, función de control, ya que en el procedimiento de debate público por el que se elabora la ley en el Parlamento, la minoría participa enmendando, criticando, haciendo oír su opinión que puede no ser admitida, al final del debate, por la mayoría, pero que puede trascender, sin duda alguna, a la opinión pública. ${ }^{69}$

En el derecho no suelen ser acertadas, pues, las soluciones extremas, quizá porque el derecho pertenece al mundo de lo relativo. Las respuestas a los problemas que hoy se plantean a la función legislativa deben ser, por ello, respuestas moderadas, soluciones intermedias, si se quiere, pero de ninguna manera radicales. Algunas ya se han propuesto: por ejemplo (y me referiré sólo a ese caso), la que se incluye en el Informe Bozzi sobre las reformas institucionales italianas. En este Informe se aboga por dotar a la

$69 \mathrm{El}$ control parlamentario de gobierno no es hoy sólo, ni principalmente, control por el Parlamento (control del gobierno por la misma mayoría) sino control en el Parlamento (control indirecto, de efectos diferidos, cuyo destinatario no es sólo el gobierno o la mayoría, sino, sobre todo, el cuerpo electoral, y que es el control que en la cámara puede efectuar la minoría). Sobre esta cuestión, capital hoy en el parlamentarismo democrático, me remito a lo que, de modo más extenso, expongo en mi trabajo "El control parlamentario como control político", cit. 
Este libro forma parte del acervo de la Biblioteca Jurídica Virtual del Instituto de Investigaciones Jurídicas de la UNAM

cámara de Diputados de prevalencia en el ejercicio de la función legislativa y al Senado de prevalencia en el ejercicio de la función de control (bicameralismo "diferenciado"), haciendo, pues, de aquella cámara la legisladora ordinaria y conservando sólo algunas categorías de leyes como bicamerales; se propugna, además, que el Parlamento nacional se ocupe sólo de las "grandes leyes" (entendidas, eso sí, en sentido amplio, es decir, los códigos, el ordenamiento judicial, el ordenamiento de la autonomía local, las leyes bancarias, etcétera) y de la "legislación de principios", atribuyéndose a las regiones (en materias de su competencia) la "legislación de desarrollo", así como al gobierno las "normas aplicativas y de detalle" mediante delegaciones permanentes o ad hoc. No sólo, pues, delegación a favor del gobierno, sino descentralización legislativa a través de los Parlamentos regionales. Y, aun así, Rodotà, en su comentario a esta parte del Informe, insistirá en la prudencia con que deben abordarse estas reformas, alertando sobre el peligro de caer en una especie de reserva reglamentaria o de producir un ordenamiento excesivamente complejo que aumente el deterioro del Parlamento como resultado indeseado de una reforma que pretendiese, paradójicamente, revalorizarlo. ${ }^{70}$

Por supuesto que en España (aun contando, a mi juicio, con mejor ordenación institucional que la actual italiana) debieran acometerse también algunas reformas. Quizá las más importantes ni siquiera exigirían cambios normativos. En ese sentido (un buen, y cada día más urgente), remedio para poner orden en nuestra "maraña" legal sería simplemente que el legislador evitase, en la mayor medida posible, las derogaciones tácitas, o, dicho más correctamente, que acudiese a la sana política legislativa de las derogaciones expresas y detalladas, no rehuyendo su responsabilidad de depuración del ordenamiento y no traspasándola, como hace hasta ahora tan generosa como deplorablemente, a los abogados y los jueces; o que sistematizase mejor

70 Teresi, F., Le riforme istituzionali. Materiali di studio, Turín, G. Giappichelli Editore, 1987, en especial, pp. 62 y 63, 73-75 y 81-113. 
Este libro forma parte del acervo de la Biblioteca Jurídica Virtual del Instituto de Investigaciones Jurídicas de la UNAM

nuestra legislación, recuperando la vieja, pero sabia, idea de los códigos, idea que sigue teniendo vigencia aunque ahora se encuentre entre nosotros, por desgracia, algo abandonada. Y en lo que se refiere a la "descentralización legislativa" territorial, además de una cierta autolimitación del legislador estatal, resultaría casi imprescindible una mayor coordinación de las políticas legislativas nacionales y regionales. ${ }^{71}$ Otras reformas precisarían de cambios normativos y, a mi juicio, quizá debieran encaminarse a soluciones próximas a las ya aludidas del Informe Bozzi, lo que ayudaría, además, a encontrar un papel más definido para nuestro Senado.

Sin embargo, y como antes ya he dicho, no creo que, sea cual sea el tipo de reformas que se acometiesen, pudiera hoy recrearse un ideal y tópico Estado legislativo que, por un lado, desterrase o redujese al mínimo la actividad "legisladora" gubernamental, y que, por otro, hiciera desaparecer el fenómeno de las leyes singulares de las que difícilmente puede desprenderse el Estado social. Las razones de eficacia, de oportunidad, etcétera, que se aducen en defensa de la licitud de los llamados reglamentos independientes no son tan sólidas en nuestro ordenamiento en cuanto que el gobierno dispone ya de un instrumento normativo formidable para remediar la omisión del legislador, como es el decreto-ley. En cambio, me parece que la legislación delegada es una buena solución técnica para la cooperación legislativa gubernamental. Legislación delegada que, por mucho que se agilice la actividad legisladora del Parlamento, resulta imprescindible en nuestros días. ${ }^{72} \mathrm{Y}$ en cuanto a la ley

71 Sobre ello llama la atención con agudeza Muñoz Machado, S., "Las deformaciones del ordenamiento jurídico y la aplicación de las leyes en el nuevo sistema constitucional", trabajo incluido en su libro Cinco estudios sobre el poder y la técnica de legislar, Madrid, Civitas, 1986.

72 Asegurar la primacía del Parlamento en lo que se refiere a la legislación delegada pasa más por la cuidadosa redacción de la ley de delegación, que por el reforzamiento de los controles parlamentarios a posteriori, cuya eficacia siempre es dudosa. Un buen estudio de derecho comparado sobre ello en Patrono, M., Le leggi delegate in parlamento, Padua, CEDAM, 1981. El mejor control es el 
Este libro forma parte del acervo de la Biblioteca Jurídica Virtual del Instituto de Investigaciones Jurídicas de la UNAM

singular, lo que quizá debiera propugnarse es su limitación (no su imposible desaparición) y su control ya que es aquí, en el control, donde reside el mayor problema de ese tipo de leyes y donde se encuentra la mayor deficiencia que existe, respecto de ellas, en el ordenamiento español, pues al no estar admitida su impugnación directa en el recurso de amparo producen en el ciudadano afectado una real indefensión. En tales casos, la impugnación indirecta de la ley (o de la norma con fuerza de ley) por virtud del artículo 55.2 de la LOTG no resuelve nada, ya que, precisamente aquí, esa vía se presenta inoperante (al tratarse de leyes autoaplicativas, que tienen efecto directo sobre el particular sin necesidad de la mediación de acto alguno aplicador). Sólo a través de la impugnación directa podría tutelarse el derecho que esas leyes lesionaran, pero, como quiera que no existe tal vía en el recurso de amparo (y el recurso o la cuestión de inconstitucionalidad no pueden instarse efectivamente por los particulares), ha de concluirse que el ciudadano no tiene tutelado jurisdiccionalmente su derecho cuando lo lesiona una ley de esa clase. De ahí la necesidad de reformar, en este punto, la LOTC para hacer posible en tales casos el recurso de amparo (lo que ya se intentó, por cierto, cuando se elaboró el Proyecto de aquella Ley, aunque entonces el intento, lamentablemente, fracasara).

Podría decirse, con toda razón, que hay problemas de la función legislativa que en este capítulo ni siquiera han sido aludidos. Algunos de tanta importancia como la actividad de los grupos de presión o de interés en el procedimiento legislativo parlamentario y, en relación con ello, la institucionalización o no de la negociación con las fuerzas sociales en dicho procedimiento, según se entienda que es o no conveniente que la negociación se celebre a "espaldas" o "fuera" de las cámaras. Suele ser muy común defender la institucionalización parlamentaria de las vías de "con-

jurisdiccional y para ello tiene una importancia decisiva la correcta formulación de la ley de delegación. Sobre la cuestión en España, Jiménez Campo, J., "El control jurisdiccional y parlamentario de los decretos legislativos", Revista de Derecho Político, España, núm. 10, 1981. 
Este libro forma parte del acervo de la Biblioteca Jurídica Virtual del Instituto de Investigaciones Jurídicas de la UNAM

cierto", por estimarse que así se evita la situación poco airosa (se dice) en que se ve la cámara, convertida en órgano ratificador de decisiones que se toman en otro lugar.

Por supuesto que este y otros muchos problemas de la función legislativa de los Parlamentos no han sido objeto del capítulo, y la razón de ello es muy simple: en este capítulo no cabe incluirlo todo y no queda más remedio que seleccionar algunos de los numerosos temas que podrían tratarse. Toda selección, por lo demás, es siempre arbitraria. Sin embargo, no querría dejar de mencionar (aunque sea breve) acerca de la "concertación social".

Ocurre que, a mi juicio, es en la fase preparatoria de los proyectos de ley donde tiene más sentido institucionalizar la concertación, por más que haya partidarios de incluir esa negociación en el ámbito parlamentario (al estilo, diríamos, norteamericano). Creo que, en un sistema en el que el gobierno, constitucionalmente, impulsa y dirige la política legislativa, es en sede gubernamental y no en sede parlamentaria donde debe institucionalizarse la concertación, sin perjuicio por supuesto, de que, a través de los grupos parlamentarios, las fuerzas sociales, por vía indirecta, presionen en los debates y en los acuerdos de las cámaras, pero eso es algo que ni resta dignidad al Parlamento ni distorsiona la representación política, lo que sí ocurre (o puede ocurrir) cuando en la propia cámara se institucionaliza la concertación. Me estoy refiriendo, como es claro, a la concertación con las fuerzas sociales, pues la concertación entre las fuerzas políticas sí que debe tener su asiento en el Parlamento, y para facilitar esa concertación se hacen necesarias determinadas reformas que van desde la mejor conformación y utilización de las ponencias hasta el replanteamiento de la publicidad del trabajo de las comisiones en determinadas fases del procedimiento legislativo.

Pero no se trata sólo de reformas técnicas; la función legislativa de las cámaras y, en general, las demás funciones parlamentarias de lo que están especialmente necesitadas en todos los Estados democráticos y, sin duda, en el nuestro más aún, es de una revita- 
Este libro forma parte del acervo de la Biblioteca Jurídica Virtual del Instituto de Investigaciones Jurídicas de la UNAM

lización de la representación y de una vigorización de los debates (sobre todo de los debates en el Pleno, de lo que el parlamentarismo inglés sigue suministrando un buen ejemplo), al objeto de que se fortalezca la legitimidad del Parlamento o, si se quiere, su importancia política a los ojos de la opinión pública. Al fin y al cabo, la tan repetida "centralidad" parlamentaria no significa, en el fondo, más que esto: que el Parlamento es el locus característico de la democracia, que no hay más democracia que la democracia parlamentaria y que, a largo plazo, la suerte del sistema depende más de las virtudes del Parlamento que de la eficacia del gobierno (aunque algunos, por error, no lo entiendan así).

Y entre las virtudes del Parlamento no está exactamente, a mi juicio, suplantar al gobierno y a la administración. Hoy el Parlamento "no puede hacerlo todo"; es decir, no puede predicar, para sí mismo, una competencia universal. Un sistema de división de poderes (con todas las rectificaciones que se quiera) exige no sólo, como es obvio, que el Parlamento no invada la función jurisdiccional, sino también que no invada la función de gobierno, función que debe gozar de un determinado nivel de autonomía (o de competencias exclusivas), pues, de lo contrario, no se entiende, entre otras cosas, cómo puede darse un conflicto de atribuciones entre Parlamento y gobierno residenciable en el Tribunal Constitucional. Aquí nos encontramos con una cuestión tan interesante y polémica como es la llamada "reserva de administración", inmediatamente conectada con el problema de las leyes singulares (pero no solamente con él, como es claro). Precisamente a la "reserva de administración" dedicó su reunión de 1984 la Asociación Alemana de Profesores de Derecho Público, sesenta años después de haber dedicado la de 1924 a las leyes-medida. Sin entrar en los detalles de este formidable problema ${ }^{73}$ lo menos que puede decirse es que hoy la función

73 Puede verse una interesante aproximación al tema, especialmente en cuanto a la doctrina alemana, en Jiménez Blanco, A., "La función legislativa y la reserva de administración. Notas sobre un nuevo concepto", en 
Este libro forma parte del acervo de la Biblioteca Jurídica Virtual del Instituto de Investigaciones Jurídicas de la UNAM

legislativa no cabe comprenderla sin ponerla en relación con la función de gobierno, y que los problemas actuales de la primera tienen mucho que ver con la actual indefinición en que se encuentra la segunda.

Varios Autores, Las Cortes Generales, Madrid, Instituto de Estudios Fiscales, 1987, vol. II. 


\section{CAPÍTULO QUINTO \\ LA INICIATIVA LEGISLATIVA}

\section{ACLARACIÓN PRELIMINAR}

$\mathrm{Al}$ iniciar quiero hacer, una advertencia previa, abordaremos el tema de la iniciativa legislativa que se ejerce en las Cortes Generales, o sea de la iniciativa para las leyes estatales, y no de la iniciativa legislativa que se ejerce en los Parlamentos de las comunidades autónomas. Por una razón fácilmente comprensible, necesitaría mucho más tiempo y el capítulo se prolongaría demasiado, o tendría que ser excesivamente superficial. Es cierto que algunas de las categorías que aquí se utilizarán pueden ser trasladables a la iniciativa para las leyes de las comunidades autónomas (cuyo sistema es una especie de retrato, a escala reducida, y con ciertas variaciones y complicaciones, del previsto en el artículo 87 de la $\mathrm{CE}$ ), pero voy a ceñirme al estudio de la iniciativa legislativa para las leyes estatales.

La segunda advertencia es que el capítulo no va a ser (constituiría, por lo demás, una inútil pretensión) una exposición en la que se intente abordarlo todo sobre la iniciativa legislativa de las leyes estatales. Más bien voy a dedicar una serie de reflexiones, por un lado, a las características generales de la iniciativa y, por otro, a algunos de los problemas que se plantean en las diversas modalidades a través de las cuales la iniciativa se ejerce, pensando que ello pueda tener un cierto interés aunque sólo sea por el hecho de que mi particular versión sobre la iniciativa legislativa no coincide en algunos puntos con los que mantiene la mayoría de la doctrina sobre la cuestión. Y lo haré con el mayor respeto, 
Este libro forma parte del acervo de la Biblioteca Jurídica Virtual del Instituto de Investigaciones Jurídicas de la UNAM

puesto que discrepo con algunos colegas, y puede que sean ellos los que tengan razón, pero creo que estas discrepancias son siempre saludables en toda disciplina científica.

\section{EL SIGNIFICADO GENERAL DE LA INICIATIVA LEGISLATIVA}

Vamos a pasar revista, en primer lugar, al significado de la iniciativa legislativa. Desde el viejo y clásico libro de Larcher, L'iniciative parlamentaire en France, de 1896, pasando por las páginas siempre brillantes que a la cuestión dedica Carré de Malberg en su Contribución a la teoría general del Estado, hasta las más recientes e importantes monografías sobre la materia de Galeotti, Spagna Musso, Lucifredi o Cuocolo, creo que es común en esa doctrina, y a mí me parece la doctrina más sólida, entender la iniciativa legislativa como el acto mediante el cual se pone en marcha obligatoriamente el procedimiento legislativo; es decir, y más concretamente, como el acto mediante el cual se abre ya paso a la fase constitutiva de ese procedimiento. $\mathrm{Y}$ yo añado, concretando aún más, se abre paso a la fase de deliberación y enmienda, o sea, a la fase de presentación de enmiendas y obligatoria deliberación sobre ellas.

Como decía Carré de Malberg, producida la iniciativa, el Parlamento se encuentra obligado, constreñido, a entrar en la discusión del texto; es decir, a entrar en la discusión de un texto que pueda ser enmendado por los parlamentarios. Ello no significa necesariamente que, al final del iter parlamentario, tenga que producirse de manera obligatoria la aparición de una ley. El Parlamento puede no aprobar ese texto, puede rechazarlo en esa fase constitutiva, pero esa es una cuestión distinta. A mi juicio, el punto fundamental radica en que, producida la iniciativa, nace la obligatoriedad de pasar, insisto, a la fase deliberante, durante la cual únicamente puede retirar el texto quien posee el derecho de iniciativa. La cámara, en cuanto cámara ejerciente de la potestad legislativa, puede rechazar un texto, no aprobarlo; pero la cámara, como órgano que tiene en ese caso la capacidad de iniciativa 
Este libro forma parte del acervo de la Biblioteca Jurídica Virtual del Instituto de Investigaciones Jurídicas de la UNAM

(no la potestad legislativa, sino la capacidad de iniciativa), puede únicamente retirarlo cuando la iniciativa se produce en su propio seno. O sea, quien tiene la capacidad de iniciar tiene la capacidad de retirar. En ese sentido es en el que decía Royer-Collard que "iniciar la ley es reinar", aunque entonces, congruentemente, esa facultad, en la Constitución francesa de 1814, la tuviese el rey.

El que posee la iniciativa tiene la libre disposición del texto hasta el momento final del proceso legislativo parlamentario, o más exactamente, hasta el momento anterior al pronunciamiento definitivo de la cámara. De tal manera que si a lo largo de la fase de elaboración del texto aquel que lo inició decide retirarlo pueda hacerlo. El gobierno puede retirar sus proyectos de ley, en cada cámara, en cualquier momento anterior al pronunciamiento definitivo de la cámara. El Congreso y el Senado, que también poseen la iniciativa legislativa, pueden acordar, en los Plenos, la retirada de las proposiciones de ley. Pero esa facultad de retirar la poseen las cámaras no por poseer la potestad legislativa, sino porque poseen la facultad de iniciativa, que es algo distinto y que no puede confundirse con lo anterior. Hay veces en las que ambas capacidades residen en el mismo órgano y hay veces en que no. Se trata, en suma, de funciones diversas.

Es cierto que se me podría objetar que hay una excepción, o unas excepciones, en nuestro ordenamiento a esto que estoy diciendo: a que la capacidad de iniciar comporta la capacidad de retirar. Tales excepciones se dan, por un lado, en la iniciativa para los Estatutos de Autonomía, que se atribuye a una "asamblea" (artículos 146 y 151.2.1 de la CE) que después no puede "retirar" el proyecto de Estatuto por ella elaborado; y, por otro, en la iniciativa para la reforma de los mismos Estatutos de Autonomía, iniciativa que está atribuida, en todos los Estatutos, además de a las Cortes Generales y a veces también al gobierno estatal (ahí no habría problemas en cuanto a la retirada), a los gobiernos y Parlamentos autónomos, que, una vez elaborado el proyecto y remitido al Congreso de los Diputados, no pueden retirarlo. 
Este libro forma parte del acervo de la Biblioteca Jurídica Virtual del Instituto de Investigaciones Jurídicas de la UNAM

Ahora bien, estas excepciones no vienen a refutar la regla general ya establecida para la iniciativa de las leyes estatales, sino a confirmarla, puesto que lo que ponen de relieve, precisamente, es el carácter extraordinariamente singular de los Estatutos de Autonomía, que, aprobándose mediante ley estatal (ley orgánica), son algo más y algo distinto de las demás leyes estatales. Ello hace "comprensible" la excepción ya aludida, pero no la "explica" completamente. La explicación se basa, por una parte, en que las "asambleas" elaboradoras de los proyectos de Estatutos son unos órganos "eventuales", "no permanentes", que mueren, como tales, una vez terminado su trabajo de elaboración, y mal podrían, después de desaparecer, volver a actuar "retirando"; y, por otra parte, la explicación más profunda, los gobiernos y Parlamentos autónomos no son órganos generales del Estado, sino parciales, o parcialmente territoriales, resultando quizá incoherente que un órgano así pudiese mediatizar la actividad legislativa de las Cortes Generales, retirando un proyecto que ya se está debatiendo en dichas Cortes. De todos modos, lo que se evidencia, una vez más, es el carácter complejo, peculiar, de esas normas que se llaman los Estatutos de Autonomía.

Para cerrar esta primera parte quiero apuntar, pues, las notas características del significado general de la iniciativa legislativa.

Por un lado, supone la capacidad de poner en marcha el procedimiento legislativo, de abrir paso a la fase constitutiva del procedimiento, que yo la entiendo como fase de presentación de enmiendas y deliberación sobre ellas.

Por otro lado, significa también capacidad de disponer libremente del texto (con la excepción, quizá, de los Estatutos de Autonomía ya aludida), de tal manera que si, como producto de la fase constitutiva, ese texto sufriese alteraciones que no deseara el órgano que lo inició, ese órgano, que tiene la potestad de iniciarlo, pueda retirarlo. O sea, poder iniciar comporta poder retirar antes de su aprobación definitiva, antes del pronunciamiento 
Este libro forma parte del acervo de la Biblioteca Jurídica Virtual del Instituto de Investigaciones Jurídicas de la UNAM

definitivo de la cámara sobre el texto. Una vez producido este hecho (el pronunciamiento definitivo de la cámara), ya hay voluntad de la cámara y ya no se puede retirar.

Por último, hay que decir que iniciativa legislativa es algo distinto de potestad legislativa y que iniciativa legislativa es también algo distinto de propuesta de iniciativa. El gobierno, que posee la iniciativa legislativa, no posee por ello la potestad legislativa (abstracción hecha del problema de los decretos-ley). Al mismo tiempo, algunos órganos o fracciones de órganos que pueden simplemente instar la iniciativa legislativa no tienen atribuida, sin embargo, la iniciativa legislativa. De tal manera, a mi parecer, iniciar es algo que no puede identificarse con promover. Es cierto que parte de la doctrina se manifiesta en el sentido de entender por iniciativa legislativa la capacidad de promover el procedimiento legislativo. Y, también, es cierto que otra parte de la doctrina, más cercana a mis planteamientos, opina que promover no es iniciar.

Yo distingo entre promover e iniciar. Ejercer la iniciativa legislativa, a mi juicio, no es promover el procedimiento legislativo, sino "iniciarlo", ponerlo irremisiblemente en marcha, que es cosa bien distinta. "Promover" e "iniciar" son dos vocablos con sentido diferente en España, tanto en el lenguaje cotidiano como en el jurídico. En el jurídico, promover la creación de una sociedad anónima es algo muy distinto a iniciarla. Promover el planteamiento de un proceso es también distinto a iniciar ese proceso. En el lenguaje coloquial "promover" e "iniciar" también son dos términos de diferente significado. No es igual "promover" la realización de un viaje que "iniciar" ese viaje. Por supuesto, ésta es una cuestión mucho más compleja y menos simple, pero quería dejar expuestas las consideraciones que anteceden ya que en ellas se expresa, a grandes rasgos, lo que entiendo por iniciativa legislativa, así como las razones en que me fundo para sostener tal entendimiento. 
Este libro forma parte del acervo de la Biblioteca Jurídica Virtual del Instituto de Investigaciones Jurídicas de la UNAM

\section{LA INIGIATIVA LEGISLATIVA EN EL DERECHO ESPAÑOL. ANTEGEDENTES HISTÓRICOS Y CARACTERÍSTICAS DEL SISTEMA ADOPTADO POR LA CONSTITUCIÓN}

Adelantadas, pues, esas consideraciones sobre las características que a mi juicio reúne lo que se llama iniciativa legislativa, veamos la iniciativa legislativa en el derecho español.

Los antecedentes históricos de nuestra iniciativa legislativa son suficientemente conocidos, la doctrina admite, pacíficamente, que hemos tenido una estructura dualista de iniciativa, rey-Parlamento, en todas nuestras Constituciones, excepto en la de 1812 y en el Estatuto Real de 1834. Incluso la Constitución republicana de 1931 establece una iniciativa dualista: concede la iniciativa al gobierno y al Congreso de los Diputados. De tal manera que las dos únicas excepciones de Constituciones con estructura monista de la iniciativa son la Constitución de 1812 (se concede la iniciativa sólo a las Cortes Generales) y el Estatuto Real de 1834 (se concede la iniciativa sólo al rey).

Pero creo que no se ha reparado suficientemente sobre la Constitución de 1812, cuando se afirma, sin más precisión, que es una Constitución que establece una iniciativa monista, un sistema monista de iniciativa. Hay algo más que conviene resaltar y poner de manifiesto. Es cierto que el artículo 132 de aquella Constitución otorga la iniciativa legislativa a las Cortes, esto es, al Parlamento y no al rey. En ese sentido cabe hablar de una estructura monista de la iniciativa. Pero en el artículo 171.14 de la misma Constitución, entre las facultades del rey, se enumera la de hacer a las Cortes las propuestas de ley o de reformas que crea conducentes al bien de la nación para que deliberen en la forma prescrita. ¿Qué le atribuye aquí? ¿Una facultad de iniciativa? No, la Constitución la atribuye a las Cortes, literal y rotundamente. Pero, ¿qué es lo que se le atribuye al rey? Una propuesta de iniciativa, una capacidad y una facultad de proponer la iniciativa. Y me interesa subrayarlo porque esto valdrá de apoyo para la tesis que yo mantengo respecto de nuestro ordenamiento actual. Las dos 
Este libro forma parte del acervo de la Biblioteca Jurídica Virtual del Instituto de Investigaciones Jurídicas de la UNAM

mejores concreciones históricas de esta distinción entre iniciativa y propuesta de iniciativa se encuentran en nuestra Constitución de 1812 y en la francesa de 1791, que son unas Constituciones de monarquía constitucional en sentido amplio, pero no en sentido estricto. En aquel tipo de Constituciones, que son exactamente de monarquía republicana, aunque el principio monárquico subsiste no está en equilibrio con el principio democrático, que es el que prevalece. Por ello, la potestad de iniciar y aprobar la ley pertenece al Parlamento. No obstante, al rey, como órgano, se le atribuyen algunas funciones, que no son funciones con capacidad de provocar modificaciones jurídicas definitivas en el ordenamiento, pero sí funciones con capacidad de provocar, al menos, la posibilidad de que otros órganos del Estado puedan ponerse en marcha una vez que son instados por el rey.

Pero dejando estos antecedentes históricos, y recordando sólo ese dato de la Constitución de 1812, pasemos a la Constitución actual, al ordenamiento jurídico vigente.

La Constitución española dedica a la iniciativa legislativa un precepto, mejor dicho, dedica un precepto a tratar generalmente esa cuestión: el artículo 87, pero no es ese el único precepto sobre la iniciativa legislativa. Es en el artículo 87 donde se habla de la iniciativa con carácter general, pero no con carácter monopolizador, pues hay otras iniciativas de las que después hablaré.

En el artículo 87 se dice, en su apartado primero, que "la iniciativa legislativa corresponde al Gobierno, al Congreso y al Senado"; en su apartado segundo, que "las Asambleas de las Comunidades Autónomas podrán solicitar del Gobierno la adopción de un proyecto de ley o remitir a la Mesa del Congreso una proposición de ley", y en su apartado tercero, que "una ley orgánica regulará las formas de ejercicio y requisitos de la iniciativa popular para la presentación de proposiciones de ley".

Fijándonos sólo en el artículo 87, como habíamos planteado, ¿tenemos una estructura de iniciativa dualista o pluralista? El apartado primero es muy rotundo, y es el único apartado que habla de iniciativa legislativa: "La iniciativa legislativa corresponde 
Este libro forma parte del acervo de la Biblioteca Jurídica Virtual del Instituto de Investigaciones Jurídicas de la UNAM

al Gobierno, al Congreso y al Senado, de acuerdo con la Constitución y los reglamentos de las Cámaras". Podemos pensar que tenemos un sistema dualista, porque en el apartado segundo no se habla ya de iniciativa legislativa, sino que se faculta a las Asambleas de las comunidades autónomas para proponer al gobierno o proponer a las cámaras, y el apartado tercero no habla tampoco estrictamente de iniciativa legislativa, sino que faculta para presentar proposiciones de ley.

Sin entrar en la discusión de si el artículo 87, en sus apartados dos y tres, regula verdaderamente la iniciativa legislativa o las propuestas de iniciativa, sin entrar en que el apartado tercero quizá deja una cláusula abierta, y tendríamos que ver esa ley orgánica que lo desarrolla, lo cierto es que aunque nos atuviéramos al apartado primero del artículo 87, y el precepto establece que sólo existe iniciativa, facultad de iniciativa, a cargo del gobierno, el Congreso y el Senado, habría que decir que no estamos en nuestro ordenamiento ante un sistema dualista de iniciativa. Porque en nuestro ordenamiento existen otros órganos dotados de auténtica iniciativa legislativa, distintos del gobierno, el Congreso y el Senado, y fuera de lo establecido en el artículo 87.

Y solamente por ello, al margen, repito, de lo que se establece en el artículo 87.2 y apartado 3, estamos ante un sistema pluralista de iniciativa. ¿Por qué? Porque, como antes dije, además del gobierno, el Congreso y el Senado, existen otros órganos en nuestro ordenamiento dotados de verdadera iniciativa legislativa. ¿De qué órganos se trata?: por un lado, de las Asambleas previstas en los artículos 146 y 151 para elaborar el proyecto de Estatuto de Autonomía, que ejercen una auténtica iniciativa legislativa, porque esa facultad significa la puesta en marcha, obligatoriamente, del procedimiento de elaboración de la ley en su fase constitutiva, sin pasar, por tanto, por la toma en consideración (el reglamento del Congreso lo deja bastante claro); y, por otro, de los gobiernos y Parlamentos autónomos para iniciar la reforma de los Estatutos, reforma que tampoco pasará (ello me parece claro) por el trámite de toma de consideración. 
Este libro forma parte del acervo de la Biblioteca Jurídica Virtual del Instituto de Investigaciones Jurídicas de la UNAM

Podemos plantearnos también si hay una iniciativa legislativa, aunque encubierta, en la disposición adicional primera de la Constitución, en donde se establece el respeto a los derechos históricos y se prevé la actualización del régimen foral. Para ello lo mejor es examinar lo ocurrido en el caso de Navarra. La Ley Orgánica de Reintegración y Amejoramiento del Fuero de Navarra, ¿se inició mediante un procedimiento distinto de los previstos en el artículo 87 o no? Esa ley orgánica tuvo una propuesta, una fase preparatoria de la iniciativa, realmente peculiar, con un claro componente "pactista", pero, en cambio, se inició regularmente, presentándose, por uno de los órganos llamados a iniciar en el artículo 87, un determinado texto, que se debatiría después en la forma ordinaria. La propuesta, pues, se llevó al Consejo de Ministros, que lo aprobó y presentó como proyecto de ley. Por tanto, a mi juicio, creo que en virtud de la disposición adicional primera no estamos ante la posibilidad de otro tipo de iniciativa, y en el caso de Navarra se ha visto que se ha respetado la iniciativa prevista en el artículo 87.1 de la CE. Cuestión distinta es la iniciativa fijada para la modificación de la propia ley orgánica ya aludida. A ello me referiré más adelante cuando trate en detalle de las modalidades de iniciativa.

\section{LAS MODALIDADES DE LA INICIATIVA LEGISLATIVA}

\section{La iniciativa gubernamental}

El artículo 87.1 de la CE es muy claro al respecto, el gobierno posee iniciativa legislativa; iniciativa, hay que decir, del gobierno y no del rey, como era el caso de la monarquía estrictamente constitucional de nuestros antecedentes históricos. Y esa iniciativa la tiene el gobierno, que la ejerce, dice la Constitución, a través del Consejo de Ministros, que no son necesariamente órganos idénticos (no hay más que ver lo que dispone el artículo 98.1 de la CE). Pero volvamos a lo que nos interesa. En la iniciativa del gobierno pueden distinguirse perfectamente la propuesta de inicia- 
Este libro forma parte del acervo de la Biblioteca Jurídica Virtual del Instituto de Investigaciones Jurídicas de la UNAM

tiva de la iniciativa propiamente dicha. ¿Cómo pueden distinguirse ambos institutos, a mi juicio diferentes? Intentaré explicarlo a continuación.

\section{A. Propuesta de iniciativa}

¿Qué es la propuesta de iniciativa en el caso del gobierno?: los anteproyectos de ley. La Ley de Régimen Jurídico de la Administración del Estado y la Ley de Procedimiento Administrativo, entre otras normas, atribuyen dicha actividad a los ministros. Esta es la propuesta de iniciativa: la que realiza un órgano, el Ministerio, que tiene capacidad de instar al órgano que posee la iniciativa, el gobierno, para que adopte o no el texto (anteproyecto) que este Ministerio le propone. Y esa fase de propuesta, en el caso de la iniciativa gubernamental, es extraordinariamente interesante, tan interesante que yo siento no poder detenerme en ella por falta de tiempo. En nuestro ordenamiento, unas veces por ley y otras por reglamento, se prevé la capacidad de determinados órganos de informar los anteproyectos de ley, la exigencia, en fin, de ciertos requisitos para la fase de elaboración de la propuesta: el informe del Consejo de Estado, el informe de los demás Ministerios, el informe y a veces el impulso de la Comisión General de Codificación, la intervención (hay que entender también que a título informativo) de otros órganos ajenos al gobierno mismo, etcétera. Sobre esta última intervención convendría, quizá, mostrar algunos ejemplos: así, el artículo 1o. de la Ley del Proceso Autonómico (LPA), dice que "antes de la aprobación por el Gobierno de un proyecto de Ley de Armonización deberá oírse a las Comunidades Autónomas"; o el artículo 108 de la LOPJ atribuye capacidad al Consejo General del Poder Judicial para informar los anteproyectos de leyes relativas a la Justicia, e incluso el artículo 131 de la $\mathrm{CE}$, prevé que el gobierno elaborará los proyectos de planificación de acuerdo con las previsiones que le sean suministradas por las comunidades autónomas y el asesoramiento y colaboración de un Consejo que se constituirá a tal efecto. 
Este libro forma parte del acervo de la Biblioteca Jurídica Virtual del Instituto de Investigaciones Jurídicas de la UNAM

Un sistema realmente complejo. Pero lo que a mí me interesa destacar es lo que ocurre si uno de esos requisitos no se cumple; es decir, si no es tenido en cuenta en la fase de propuesta. Aquí sucintamente han de distinguirse dos supuestos: uno, la ley en vigor, y otro, el acto de la iniciativa. Con la ley ya en vigor todo requisito legal o reglamentario sobre la propuesta es, a mi juicio, irrelevante. La ausencia de cualquiera de esos requisitos no convierte a la ley en una ley inválida. Salvo, quizá, y este es el problema, esa colaboración de que se habla en el artículo 131 de la $\mathrm{CE}$, porque es un requisito constitucional. La cuestión es muy discutible e interesante.

Antes de que se produzca la ley, la denuncia de cualquiera de esos requisitos, ¿a qué podría dar lugar? Podría dar lugar a un conflicto de atribuciones, si el requisito que falta es el informe del Consejo General del Poder Judicial, según lo previsto en la LOTC; o en el caso de que se alegue por una comunidad autónoma el no haber sido oída por el gobierno, según establece el artículo 1o. de la LPA, podría plantearse, quizá, un conflicto de competencias.

\section{B. Iniciativa}

La propuesta de iniciativa es una fase, pues, de la preparación del texto, pero esa fase de propuesta es muy distinta de la fase de iniciativa gubernamental. La iniciativa se produce por la aprobación de la propuesta en el Consejo de Ministros, el anteproyecto se convierte en proyecto y pasa al Congreso de los Diputados siempre, salvo en una sola ocasión, cuando se trata de proyectos de ley de distribución de los recursos del Fondo de Compensación interterritorial, que han de ser presentados en el Senado y no en el Congreso. Salvo en ese supuesto, todas las demás iniciativas legislativas gubernamentales se presentan en el Congreso. Existe una preferencia para su tramitación y no existe toma en consideración. Y, justamente, no existe toma en consideración porque es una auténtica iniciativa. 
Este libro forma parte del acervo de la Biblioteca Jurídica Virtual del Instituto de Investigaciones Jurídicas de la UNAM

A mi juicio esa ausencia, explicada generalmente por la doctrina como una consecuencia del carácter prevalente del gobierno en los regímenes parlamentarios de gabinete, dada la necesidad que tiene un gobierno de dominar la línea esencial del indirizzo politico, se debe en verdad, sobre todo, a que el proyecto de ley es una auténtica iniciativa, pues si hubiese toma en consideración no sería iniciativa, ya que "iniciar" la ley es obligar a que se abra la fase deliberante. La toma en consideración no es fase deliberante, porque le falta para que sea fase deliberante la posibilidad de presentar enmiendas, con la constancia de su presentación, con el tiempo para meditarlas y con la obligación de la cámara de entrar a deliberar sobre ellas.

El hecho de que pueda haber enmiendas a la totalidad, de devolución o alternativas, que obliguen a un debate de totalidad no contradice en absoluto mi tesis. Porque se trataría de una primera lectura, posible también en el caso de proposiciones de ley. Es un momento en que la cámara puede, por supuesto, rechazar el texto, pero después de haber abierto el proceso de presentación de enmiendas. Ya se está, en consecuencia, en la fase deliberante, de ahí que una cosa sea la primera lectura y otra distinta la toma en consideración. Por tanto, como en los proyectos de ley no hay toma en consideración, se trata de auténticas iniciativas.

Si "iniciar" consiste en poder retirar, entonces hay que decir que también aquí nos encontramos ante una iniciativa legislativa. El artículo 128 del reglamento del Congreso establece que "el Gobierno podrá retirar un proyecto de ley en cualquier momento de su tramitación ante la Cámara, siempre que no hubiere recaído acuerdo final de ésta". Asimismo, el artículo 127 del reglamento del Senado establece: "Los proyectos de ley presentados por el Gobierno pueden ser retirados por éste en todas las fases del procedimiento anteriores a su aprobación definitiva por la Cámara". ¿Eso qué quiere decir? A mi juicio, que los textos que se presentan por parte del gobierno en el Congreso, los que se presentan en el Senado, así como los que pasan del Congreso 
Este libro forma parte del acervo de la Biblioteca Jurídica Virtual del Instituto de Investigaciones Jurídicas de la UNAM

al Senado, e incluso los que, modificados por éste, vuelven nuevamente al Congreso, puede el gobierno retirarlos. O sea, el gobierno tiene la libre disposición de ese proyecto hasta antes de la última manifestación de voluntad de la cámara. Por eso se trata de una auténtica iniciativa.

Es conocido que hoy en día el mayor porcentaje de iniciativas legislativas las realiza el gobierno y no las cámaras. Se trata de una situación comprensible a la que conduce el parlamentarismo racionalizado de nuestro tiempo. De todos modos, esa regla no se cumple enteramente en Italia, donde son numerosas las iniciativas parlamentarias (en la primera legislatura se produjeron 1,375 iniciativas parlamentarias y 2,457 iniciativas gubernamentales; en la segunda legislatura, 2,514 parlamentarias y 1,667 gubernamentales; en la tercera legislatura, 3,686 parlamentarias y 1,569 gubernamentales; en la cuarta legislatura, 3,576 parlamentarias y 1,442 gubernamentales).

Ahora bien, lo que resulta aún más claro es el predominio absoluto no de las iniciativas gubernamentales, sino del número de leyes procedentes de iniciativa gubernamental sobre el número de leyes procedentes de iniciativa parlamentaria (predominio rotundo incluso en la propia Italia como lo prueba el hecho de que en la primera legislatura, de las 2,318 leyes producidas, 2,054 procedían de la iniciativa de gobierno; en la segunda legislatura, de las 1,897 leyes producidas, 1,414 procedían de la iniciativa del gobierno; en la tercera legislatura, de las 1,796 leyes producidas, 1,300 procedían de la iniciativa del gobierno; en la cuarta legislatura, de las 1,478 leyes producidas, 1,058 procedían de la iniciativa del gobierno). En España, de marzo de 1979 al 15 de enero de 1986, se promulgaron 446 leyes que procedían de la iniciativa gubernamental y 83 que procedían de la iniciativa parlamentaria.

Merece la pena detenerse, brevemente, en otra cuestión: la de los requisitos de la iniciativa gubernamental. El primero, la aprobación del texto por el Consejo de Ministros es un requisito imprescindible y, como tal, su ausencia originaría un defecto insubsanable para la validez de la ley. El segundo (el acompañamiento 
Este libro forma parte del acervo de la Biblioteca Jurídica Virtual del Instituto de Investigaciones Jurídicas de la UNAM

a la cámara, artículo 88 de la CE, "de una exposición de motivos y de los antecedentes necesarios para pronunciarse" sobre el texto) es un requisito prescindible y cuya ausencia daría lugar, pues, a un defecto subsanable; si el gobierno no lo envía, la cámara lo puede exigir, pero también puede darse por satisfecha sin él, y en tal sentido la inobservancia del requisito no supondría, nunca, un vicio de invalidez para la futura ley.

\section{La iniciativa parlamentaria}

Al tratar de la iniciativa parlamentaria intentaré exponer desde el principio mi punto de vista: en España la iniciativa la poseen las cámaras y no los parlamentarios o los grupos parlamentarios. La iniciativa la poseen el Congreso y el Senado y no sus miembros, como ocurre, por el contrario, en la República Federal Alemana, Italia o Francia, por ejemplo.

La doctrina española suele dividirse acerca de esta cuestión. Hay quienes opinan como yo y hay quienes, por el contrario, atribuyen la iniciativa a los parlamentarios o a los grupos parlamentarios, amparándose en lo dispuesto en el artículo 108 del reglamento del Senado y en el artículo 126 del reglamento del Congreso.

Voy entonces a seguir en este punto el mismo sistema utilizado antes al examinar la iniciativa del gobierno, diferenciar propuesta de iniciativa, de iniciativa.

\section{A. Propuesta de iniciativa}

En nuestro ordenamiento quien tiene la propuesta de iniciativa son los parlamentarios y los grupos parlamentarios, facultad que ejercen presentando proposiciones de ley. Pero, ¿por qué la presentación de la proposición de ley es una propuesta y no una verdadera iniciativa? Porque existe la toma en consideración, porque la propuesta no posee capacidad para obligar a la cámara a que se abra la fase deliberante del procedimiento legislativo. El 
Este libro forma parte del acervo de la Biblioteca Jurídica Virtual del Instituto de Investigaciones Jurídicas de la UNAM

hecho de presentar una proposición de ley no puede forzar a la cámara a que se inicie el trámite de enmiendas y de deliberación sobre ellas. Los plenos de las cámaras tienen que pronunciarse, primero y simplemente, sobre si aceptan o no esa propuesta.

La presentación de proposiciones de ley no es iniciativa sino propuesta, porque, además, tampoco se tiene la facultad de retirar (facultad de retirar a lo largo de todo el proceso legislativo, antes de su final). Como se sabe, el autor o los autores de la propuesta de iniciativa sólo pueden retirarla libremente antes de la toma en consideración. Tomada en consideración es ya iniciativa de la cámara. Son ambas cámaras las titulares de la iniciativa. Y eso es lo que permite también darle congruencia al artículo 134, apartado 6, de la CE, que establece que "toda proposición o enmienda que suponga aumento de los créditos o disminución de los ingresos presupuestarios requerirá la conformidad del Gobierno para su tramitación”. Ese derecho, de oponerse a una proposición (a una enmienda no plantea problemas, porque una enmienda no es estrictamente una propuesta de ley), si pudiese ejercerse después de adoptada la iniciativa, supondría una flagrante contradicción con nuestro sistema parlamentario, o más exactamente, con nuestra forma de gobierno. ¿Podría el Ejecutivo disponer libremente de algo que no es suyo, de algo que se inicia en la cámara? El reglamento del Congreso explica muy bien esta facultad: la puede ejercitar el gobierno antes de la toma en consideración. La puede ejercitar sobre algo que no es iniciativa, sino propuesta de iniciativa.

\section{B. Iniciativa}

La iniciativa legislativa parlamentaria se produce, de acuerdo con lo que antes se ha dicho, no en el momento de la presentación de la proposición de ley, sino en el momento de su toma en consideración. Por ello la poseen las cámaras (los plenos) y no los parlamentarios a título singular. El acto de la cámara tomando en consideración el texto, iniciando, pues, verdade- 
Este libro forma parte del acervo de la Biblioteca Jurídica Virtual del Instituto de Investigaciones Jurídicas de la UNAM

ramente, la ley, abre el paso, obligatoriamente, a la fase de deliberación y enmienda y faculta a la cámara (y sólo a ella) para acordar la retirada del texto en cualquier momento posterior, antes de la aprobación definitiva (artículo 129 del reglamento del Congreso). El artículo 109 del reglamento del Senado guarda silencio sobre el particular, pero hay que admitir (puesto que posee la iniciativa) que el pleno del Senado ha de tener también (como el del Congreso) la facultad de retirar, a lo largo de todo el procedimiento legislativo y antes de su aprobación definitiva, los textos iniciados en él.

Dicho esto, ¿por qué, si está claro, al menos a mi juicio, en nuestro sistema constitucional que la iniciativa es una iniciativa orgánica, atribuida a cualquiera de las dos cámaras, se crean sobre ello tantos problemas? ¿Por qué hay quienes defienden, por supuesto con sus razones, la tesis de que la iniciativa no la poseen las cámaras, sino, literalmente, que se ejerce la iniciativa cuando se presenta una proposición de ley ante la Mesa? Yo respeto esa opinión, pero no coincido con ella, lo que no significa que crea que esa opinión, contraria a la mía, sea gratuita ni mucho menos.

Es cierto que los términos que utilizan los reglamentos del Congreso y del Senado son algo confusos (se habla de "iniciativa legislativa" atribuyéndosela a las cámaras, artículo 108 del reglamento del Congreso, pero también de "iniciativa" para presentar proposiciones de ley, artículo 126 del reglamento del Congreso y artículo 108 del reglamento del Senado, atribuyéndosela a los parlamentarios); pero también es cierto que la confusión no es tanta, ya que se distingue la "iniciativa legislativa" de la "iniciativa para... la iniciativa", y ello no puede significar más que propuesta de iniciativa, aparte de que la confusión reglamentaria adonde no debe conducir es a interpretaciones contrarias a lo que dispone la Constitución misma. Lo que ocurre, a mi juicio, es otra cosa, y es que los defensores de esa opinión (que no comparto) son tributarios de una situación, muy generalizada, bastante comprensible, pero no por ello enteramente aceptable. Me refiero al hecho de que aquí en España se ha recibido la doctrina 
Este libro forma parte del acervo de la Biblioteca Jurídica Virtual del Instituto de Investigaciones Jurídicas de la UNAM

italiana y no se ha reflexionado, quizá, suficientemente sobre ella. Voy a intentar explicarlo.

Todo el problema, toda la discusión teórica, se origina en Italia con el Estatuto Albertino de 1848. Ahí está la raíz de la cuestión. El Estatuto Albertino, fiel a la influencia que recibe de nuestra Constitución de 1812, establecerá que la iniciativa legislativa la poseen las cámaras. Pero en la Europa de aquel tiempo, las diversas Constituciones (todas menos las españolas) dirán algo distinto: la iniciativa legislativa la poseen los parlamentarios. El Estatuto Albertino, de acuerdo con nuestra tradición, seguirá manteniendo que la iniciativa corresponde a las cámaras, pero ¿qué hace entonces el reglamento parlamentario italiano?: atribuir la iniciativa legislativa a los miembros de las cámaras, como en Europa era normal en el siglo XIX. Y ¿por qué? Por ser congruente con la forma de gobierno: un parlamentarismo liberal de Parlamentos, atomizados. El Estatuto Albertino, en su artículo 10, atribuía la iniciativa legislativa a las cámaras, pero la doctrina italiana de finales del siglo XIX y primeros del XX (sobre todo Espósito y Romano), ateniéndose más a los reglamentos de las cámaras que al texto de la Constitución misma, atribuyó la iniciativa legislativa a los parlamentarios. ¿En qué consiste entonces la toma de consideración?; dirán estos autores: consiste en un simple requisito de eficacia del, acto de iniciativa, que ha de imputarse como acto del parlamentario singular. Estamos ante un acto complejo que impone la necesidad de una determinada concurrencia. La toma en consideración es, pues un simple requisito de eficacia. En el fondo, la solución teórica que encontraron no dejaba de ser una especie de juego malabar, en cuanto que se montaba un acto complejo en el que, paradójicamente, el acto principal (la libre voluntad del Pleno expresada en la toma en consideración) aparecía como acto auxiliar o secundario.

Pero ésta no fue toda la doctrina. En Italia habría otros autores, como Donati, Racioppi, Brunelli, que dirán, de conformidad con el texto de la Constitución, que la iniciativa legislativa se atribuye a las cámaras, y que la toma en consideración es el instru- 
Este libro forma parte del acervo de la Biblioteca Jurídica Virtual del Instituto de Investigaciones Jurídicas de la UNAM

mento mediante el cual se realiza la iniciativa y que demuestra que ésta la tiene la cámara y no el parlamentario singular. Este sector de la doctrina sostendrá, pues, que la iniciativa era de la cámara. Y sólo, pasará, por fin, a ser de los parlamentarios cuando, a partir de 1947, lo diga la nueva Constitución, no antes.

Yo creo que ahí está el origen de la división y del enfrentamiento dentro de la doctrina española, se está aplicando acríticamente la doctrina italiana de ahora, cuando resulta que allí tienen una Constitución que dice, en este punto, lo contrario que la nuestra, o que no se ha valorado suficientemente la doctrina italiana de antes sobre el Estatuto Albertino.

No puedo entrar a profundizar más en este punto porque representaría una explicación excesivamente larga y requeriría mucho más tiempo. También hay otras cuestiones, que son de naturaleza menor, pero que han de tenerse en cuenta. Por ejemplo, los límites de la iniciativa de las cámaras. Tres son esas limitaciones: por un lado, las leyes de presupuestos y las leyes de planificación, que la Constitución dispone que el gobierno las elaborará y las presentará, y, por otro, la elaboración de los Estatutos de Autonomía, que no pueden ser objeto de iniciativa de las cámaras, salvo los previstos en el artículo 144, inciso b, de la CE.

\section{La llamada iniciativa legislativa de las comunidades autónomas}

La facultad de las Asambleas de las comunidades autónomas de solicitar del gobierno la adopción de un proyecto de ley o remitir a la Mesa del Congreso una proposición de ley (artículo 87.2 de la $\mathrm{CE}$ ) no supone el ejercicio de una iniciativa legislativa, sino de una propuesta de iniciativa. Y ello es así porque, en el primer supuesto, el gobierno es enteramente libre para adoptar o no el proyecto de ley, o más exactamente, para que ese texto llegue a convertirse, por la aprobación del Consejo de Ministros, en una auténtica iniciativa, es decir, en un proyecto de ley en sentido estricto. De tal manera, que si se envía por la Asamblea un texto 
Este libro forma parte del acervo de la Biblioteca Jurídica Virtual del Instituto de Investigaciones Jurídicas de la UNAM

articulado, su denominación exacta sería más bien la de "anteproyecto" (es decir, propuesta o proposición de proyecto).

No se está, a mi juicio, aunque parte de la doctrina así lo califique, ante una modalidad del ejercicio del derecho de petición por parte de la Asamblea, sino, exactamente, ante el ejercicio de la propuesta de iniciativa legislativa, semejante a la que realiza un ministro al presentar al Consejo un anteproyecto de ley. Sólo si el Consejo de Ministros lo acepta, el proyecto nace como tal y se envía al Congreso y en ese caso la iniciativa es del gobierno y no de la Asamblea de la comunidad autónoma o del ministro. Ésta, como el ministro, lo que ejerce, pura y simplemente, es la propuesta de iniciativa legislativa y así debe entenderse la facultad atribuida por el artículo 87.2 de la $\mathrm{CE}$ en el primer supuesto que se está considerando.

En cuanto al segundo supuesto (remitir a la Mesa del Congreso una proposición de ley), nos encontramos en una situación análoga a la anterior. Se trata, no de una iniciativa, sino de una propuesta de iniciativa, porque la referencia constitucional a la delegación por parte de la Asamblea de un máximo de tres miembros de la misma para encargarse de la defensa de ese texto ante el Congreso, se concreta en el reglamento de dicha cámara (artículo 127) a través del trámite de la toma en consideración. El pleno es enteramente libre para adoptar o no la proposición, de manera idéntica a cuando la presentan sus propios miembros; es decir, cuando la presentación de una proposición se hace por los parlamentarios. En consecuencia, no hay iniciativa legislativa en este caso, como no la hay tampoco cuando el texto procede de los miembros del Congreso. La facultad de las Asambleas legislativas de las comunidades autónomas (y la de los propios parlamentarios de las Cortes Generales) de presentar proposiciones de ley es simplemente el ejercicio de la propuesta de iniciativa. La iniciativa propiamente dicha la ejerce la cámara en el acto de la toma en consideración.

Es cierto que el reglamento del Congreso, en su artículo 108, con alguna incoherencia, denomina a esta facultad de las Asam- 
Este libro forma parte del acervo de la Biblioteca Jurídica Virtual del Instituto de Investigaciones Jurídicas de la UNAM

bleas de las comunidades autónomas "iniciativa legislativa", pero tal denominación resulta contradicha por la propia regulación que a la figura se otorga en el mismo reglamento, ya que impone el trámite de toma en consideración, equiparando totalmente estas proposiciones a las de origen parlamentario. Hay que entender, entonces, que el artículo 108 emplea, en este caso, el término "iniciativa" de manera exclusivamente retórica, por no decir de manera errónea, puesto que aquí no hay iniciativa sino, en verdad, propuesta.

Los límites de esta propuesta son los mismos que los de las propuestas de iniciativas parlamentarias; es decir, de las proposiciones de ley. No parece correcto circunscribir el ejercicio de esta facultad de las Asambleas legislativas de las comunidades autónomas a las materias que afectan al ámbito de sus "intereses respectivos", porque aquí no debe jugar la regla del artículo 137 de la CE, prevista para la actividad interna de las comunidades, pero no para la participación de esas comunidades en la actividad de órganos generales del Estado. Ese es el argumento decisivo, pues, y no el que pudiera extraerse del hecho de que esta propuesta esté admitida para las reformas de la Constitución. Si la proposición de ley enviada por una comunidad autónoma puede tener por objeto la reforma constitucional (artículo 166 de la $\mathrm{CE}$ ) ello significa, se ha dicho por algunos, que no puede haber límites materiales de cualquier género a ese tipo de proposiciones (abstracción hecha de las leyes de presupuestos y las de planificación). Quien puede lo más, puede lo menos. Sin embargo, tal argumento no sería, por sí mismo, suficiente, porque si se acepta que el límite del artículo 137 es general, la capacidad de las comunidades (mejor dicho, de sus Asambleas) para proponer reformas a la Constitución también estaría limitada al ámbito de sus respectivos intereses (reformas de la Constitución que afectaren a materias de distribución territorial del poder).

El argumento decisivo, como antes se dijo, donde reside es en la improcedencia de aplicar a este supuesto lo que prevé el artículo 137 de la Constitución. Solución, además, que se refuerza por 
Este libro forma parte del acervo de la Biblioteca Jurídica Virtual del Instituto de Investigaciones Jurídicas de la UNAM

el hecho de que no se está ante una iniciativa auténtica, sino ante una propuesta de iniciativa, de tal manera que no es la Asamblea de la comunidad autónoma sino el Pleno del Congreso el que decide, libremente, si pone o no en marcha el procedimiento de deliberación y aprobación de la ley. En estas condiciones, tampoco, desde el punto de vista práctico, tiene mucho sentido limitar excesivamente esta facultad de las Asambleas legislativas de las comunidades autónomas.

\section{La iniciativa popular}

En el artículo 87.3 de la CE se dice "iniciativa popular", no "iniciativa legislativa popular", pero por la ausencia de una palabra no puede llegarse, de ningún modo, a interpretaciones que negasen, constitucionalmente, la posibilidad de que aquí se prevea una verdadera iniciativa legislativa. Ni siquiera ello se desprende, inmediatamente, de que en el mismo artículo se siga diciendo que el objeto de la figura es la "presentación de proposiciones de ley" (presentar una proposición es, en nuestro derecho parlamentario, ejercer la propuesta y no exactamente la iniciativa legislativa). Todo depende (más bien dependía) de la regulación que a esta iniciativa se otorgase por la ley orgánica llamada a establecerla, que ha sido la 3/1984, del 26 de marzo.

Si nos atenemos sólo al título de la Ley y al enunciado que se contiene en su artículo 1o. (en ambos se denomina a este instituto "iniciativa legislativa popular"), parecería que la cuestión ya está resuelta, pero resulta que ello no es así, porque los restantes preceptos de la norma vienen a contradecir frontalmente la calificación que en su título y en su artículo 1o. se otorga, y esta iniciativa popular no será iniciativa legislativa, sino propuesta de iniciativa. Y ello es así porque en el artículo 13 de la Ley (y también en el artículo 126 del reglamento del Congreso) se exige, para este caso, la toma en consideración por el Pleno de la cámara. Se trata, pues, de una propuesta análoga a la que se encierra en la presentación de proposiciones de ley por los parlamentarios 
Este libro forma parte del acervo de la Biblioteca Jurídica Virtual del Instituto de Investigaciones Jurídicas de la UNAM

o por las Asambleas legislativas de las comunidades autónomas. De todos modos, no deja de ser un contrasentido que lo que la Constitución denomina "iniciativa" quede después, en su regulación legal, reducido a "propuesta".

Al margen de esta cuestión, la ley orgánica plantea otros problemas. Quizá el primero sería que llama (artículo 4o.) "iniciativa" (hay que entender que "iniciativa para... la iniciativa", de acuerdo con lo que antes se ha dicho) a un trámite que no lo es (el de la presentación del texto por la Comisión promotora); lo que aquí se inicia es el procedimiento destinado a que, en su momento (artículo 12 de la ley), se formule la verdadera iniciativa popular (presentación de las firmas de los electores; es decir, elevación a la cámara de la voluntad, fehaciente, de la fracción del electorado que solicita la adopción de la proposición de ley), que es el acto de auténtica "iniciativa... para la iniciativa", esto es, de propuesta de iniciativa legislativa. De todos modos, aquí, más que un problema, lo que hay es una defectuosa redacción.

En cuanto a los límites de la iniciativa popular, poco puede decirse por lo que se refiere a las materias excluidas (artículo 2o.) ya que se trasladan a la ley orgánica las exigencias constitucionales, con un error, por cierto, al no mencionarse las reformas de la Constitución que, claramente, están excluidas de la iniciativa popular (artículo 166 de la GE); en cambio, algunos problemas suscitan las causas de inadmisión (artículo 5o.), especialmente la última (apartado $f$ ): la previa existencia de una proposición no de ley. Parece excesivo que ello opere como causa de inadmisión, en cuanto que, obviamente, ese tipo de proposiciones, como su nombre indica, no tienen por objeto la emanación de normas, que es justamente el fin de la iniciativa popular. Existe, de modo casi inevitable, un amplio margen de discrecionalidad en la apreciación, por parte de la Mesa del Congreso, de las causas de inadmisibilidad. Ello puede subsanarse en la medida en que hay recurso de amparo ante el Tribunal Constitucional contra la resolución de la Mesa (artículo 6o. de la ley), recurso quizá comprensible, aunque con muchos reparos, desde el punto de 
Este libro forma parte del acervo de la Biblioteca Jurídica Virtual del Instituto de Investigaciones Jurídicas de la UNAM

vista del órgano que produce la decisión y del derecho de participación, que se ejerce mediante la iniciativa popular, pero que, tal como están previstas las causas de inadmisión, le lleva al Tribunal a ampliar, de manera muy singular, por lo extensa, el canon o parámetro de la constitucionalidad.

Es curioso comprobar cómo, por lo que se refiere a las materias excluidas, nuestros constituyentes las hayan previsto para la iniciativa popular y no para el referéndum (y la explicación completa no reside en que el referéndum esté destinado a "decisiones políticas" y no a normas), cuando resulta que en Italia, Francia o Suiza, materias análogas se excluyen del referéndum de iniciativa popular, pero no de la iniciativa legislativa popular en sentido estricto. De todos modos, quizá el problema más interesante sea el de la interpretación de los límites. A mi juicio, y dado que las instituciones de democracia directa hay que considerarlas como excepción en nuestro sistema constitucional de democracia representativa, se impondría una interpretación extensiva de los límites si se tratase de referéndum o de verdadera iniciativa legislativa (es decir, de auténticos institutos de democracia directa), pero, en la medida en que aquí lo que existe es sólo propuesta de iniciativa (solicitud a la cámara y no participación en la adopción de decisiones), la interpretación que debe prevalecer de los límites es, indudablemente, de naturaleza restrictiva; es decir, a favor de la ampliación de la capacidad de propuesta de iniciativa legislativa popular.

Por último, quizá podría aludirse a otra cuestión, ciertamente interesante: la de la retirada de la iniciativa popular. En Suiza, como se trata de una auténtica iniciativa legislativa, la retirada siempre es posible. En Italia existe alguna polémica sobre ello, y así, por ejemplo, algunos autores (Bettinelli) defienden que sólo pueden retirar el texto los mismos firmantes, y otros (Spagna Musso) consideran que para la efectividad de la retirada basta que el número de firmantes que la apoye (de entre los que en su día presentaron el texto) haga rebajar la cifra de firmas a una cantidad inferior a la requerida para el ejercicio de la iniciativa. 
Este libro forma parte del acervo de la Biblioteca Jurídica Virtual del Instituto de Investigaciones Jurídicas de la UNAM

En España, a mi juicio, deben distinguirse tres momentos: antes de la recogida de las firmas, parece no haber dudas en que el texto puede retirarse por la misma Comisión promotora (por cualquier causa y no sólo por la prevista en el artículo 6.3 de la Ley); después de la recogida y presentación de las firmas y antes de la toma en consideración, creo que no sería necesario para producir la retirada que todos los firmantes desistieran, bastaría que lo hiciese un número que rebajase a menos de 500,000 las firmas que se exigen; después de la toma en consideración por la cámara, nadie, excepto la cámara misma, puede retirar el texto, puesto que es a la cámara a la que se atribuye, en definitiva, la iniciativa legislativa auténtica y la que tiene, por ello, la libre disponibilidad del texto a lo largo del procedimiento legislativo.

\section{La iniciativa para la aprobación y reforma de los Estatutos de Autonomía}

Ya me referí a estas modalidades de iniciativa al examinar las características generales del sistema. Parece claro que, en cuanto a la elaboración de los Estatutos (con la excepción de la vía prevista en el artículo 144, inciso $b$, de la CE), la iniciativa que ejercen las «asambleas» aludidas en los artículos 145 y 151 de la norma constitucional es una iniciativa auténtica, porque no existe toma en consideración por el Congreso de los Diputados, aunque, excepcionalmente, por las razones que también entonces señalé, los que ejercen la iniciativa no puedan, después, retirarla.

Me parece que tiene más interés dedicarle cierta atención al otro supuesto: la iniciativa para la reforma estatutaria. Ya adelanté que en todos los Estatutos se atribuye esa iniciativa a los gobiernos y Parlamentos autónomos, así como a las Cortes Generales (con algunas excepciones) y a veces también al gobierno del Estado. La cuestión es bastante compleja y exige que la tratemos con algún detalle. 
Este libro forma parte del acervo de la Biblioteca Jurídica Virtual del Instituto de Investigaciones Jurídicas de la UNAM

\section{A. Iniciativa de los gobiernos y Parlamentos autónomos}

Iniciativa prevista en todos los Estatutos con una única excepción: la Ley Orgánica de Reintegración y Amejoramiento del Régimen Foral de Navarra otorga la iniciativa de reforma al gobierno autónomo (la Diputación foral) y no al Parlamento. El procedimiento a través del cual se ejerce la iniciativa es, por obra de los Estatutos, pero sobre todo de los reglamentos parlamentarios, bastante similar en las diversas comunidades autónomas, salvo en Navarra, por lo que antes se dijo, y en Murcia, donde el reglamento parlamentario articula un proceso muy particular. En consecuencia, me ocuparé de lo que podría llamarse el régimen común y pasaré después a las excepciones navarra y murciana.

El régimen común de la iniciativa autonómica de reforma de los Estatutos consiste en un complejo proceso de preparación de esa iniciativa (o fase de propuesta) en la que se atribuye, al gobierno o a los parlamentarios, la capacidad de instar la iniciativa a través de un proyecto o una proposición de ley, que después ha de recorrer en la cámara todo el proceso de enmienda, debate y aprobación; es decir, todo el iter parlamentario de elaboración legislativa, con la peculiaridad de que para la aprobación del texto final por la cámara (salvo cuando se trate de reformas de escasa importancia, extremo previsto en ciertos Estatutos), se requieren mayorías cualificadas (dos tercios en Cataluña, Galicia, Cantabria, La Rioja, Aragón, Extremadura, Madrid, Castilla y León; tres quintos en Andalucía, Valencia y Asturias, y mayoría absoluta en el País Vasco, Castilla-La Mancha, Canarias y Baleares). $\mathrm{Al}$ final de ese proceso nos encontramos, pues, con una especie de ley aprobada por el Parlamento autónomo que se convierte en iniciativa legislativa ante las Cortes Generales. La iniciativa primera, es decir, la atribuida a los gobiernos y Parlamentos autónomos para la reforma del Estatuto, lo es, en verdad, para promover, poner en marcha, el procedimiento interno (autónomo) de reforma estatutaria, o en otras palabras, para preparar 
Este libro forma parte del acervo de la Biblioteca Jurídica Virtual del Instituto de Investigaciones Jurídicas de la UNAM

la iniciativa (es decir, ejercer una especie de propuesta de iniciativa), pero, al final, el órgano que ejerce la iniciativa ante las Cortes Generales es la cámara legislativa autónoma, al aprobar el texto definitivo en el que esa iniciativa se concreta y remitirlo a las Cortes Generales para su tramitación como proyecto (quizá sería mejor decir "proposición", aunque se trata de una proposición muy singular) de ley orgánica (sin pasar en las Cortes, como es obvio, por el trámite de la toma en consideración). Y ello es así en todos los supuestos: salvo en determinados casos en que algunos Estatutos prevén (los del País Vasco, Cataluña, Galicia y Andalucía) que, para las reformas que tuviesen por objeto la mera alteración de la organización en los poderes públicos y que no afecten a las relaciones de la comunidad autónoma con el Estado, bastará la consulta a las Cortes Generales del texto de la iniciativa, sin perjuicio de la aprobación final, necesaria, de éstas. De todos modos, las Cortes siempre pueden decidir, en esos casos, que la reforma excede de tales limitaciones y que ha de seguirse el procedimiento general, aparte de que la peculiaridad en cuestión ha de conectarse con la exigencia del referéndum para la reforma de tales Estatutos. En definitiva, la iniciativa instada por el gobierno o la cámara de la comunidad se concreta a través del proceso parlamentario autónomo y se formula, en verdad, por la Asamblea legislativa al adoptar un texto final que representará la auténtica iniciativa de reforma de una ley orgánica estatal, como es el Estatuto, cualidad que éste nunca puede dejar de poseer pese a los importantes rasgos que lo diferencian de las demás leyes orgánicas.

La especificidad del procedimiento de iniciativa para la reforma del Estatuto de Murcia deriva del reglamento parlamentario y no del Estatuto, que en esta cuestión sigue el modelo común que acaba de examinarse. En este punto será, pues, el reglamento parlamentario el que se aparte de tal modelo (es decir, de los demás reglamentos de cámaras autónomas) al disponer (artículo 104) que la iniciativa para la reforma del Estatuto se ajustará al procedimiento establecido por el artículo 87.2 de la Constitución 
Este libro forma parte del acervo de la Biblioteca Jurídica Virtual del Instituto de Investigaciones Jurídicas de la UNAM

para presentar proposiciones de ley ante el Congreso de los Diputados. En verdad, tal sistema no se diferencia sustancialmente, en cuanto a su regulación por el reglamento parlamentario de Murcia, del modelo común al que antes nos hemos referido, dado que se sigue, en el seno de la Asamblea legislativa, la misma tramitación que en los casos de proyectos y proposiciones de ley. La única diferencia de peso estriba en el enlace que expresamente se formula con la figura prevista en el artículo 87.2 de la $\mathrm{CE}$, cuando resulta que lo que en dicho ar-tículo se prevé es algo muy distinto a la iniciativa para la reforma de los Estatutos.

El problema que entonces puede plantearse es, justamente, el de la toma en consideración (a la que el propio artículo 104 del reglamento parlamentario murciano parece hacer referencia) por el Congreso de los Diputados. Toma en consideración preceptiva para todas las "propuestas" de iniciativa amparadas en el artículo 87.2 de la CE (y precisamente por ello son "propuestas" y no verdaderas "iniciativas"), pero que sería inadmisible para la iniciativa de reforma estatutaria, que no es propuesta sino iniciativa auténtica (los términos del artículo 147.3 de la CE y del artículo 55 del Estatuto de Murcia son claros a este respecto). De ahí que, pese a la indudable confusión del reglamento parlamentario autonómico, deba concluirse que el texto adoptado por la Asamblea legislativa (en el que se concreta la iniciativa) no habrá de pasar, en el Congreso de los Diputados, por el trámite de toma en consideración.

La otra peculiaridad a la que antes me referí afecta al caso de Navarra. La iniciativa para la reforma de la Ley Orgánica de Reintegración y Amejoramiento del Fuero (que ha de considerarse como un verdadero Estatuto de autonomía, y así lo tiene confirmado el Tribunal Constitucional) no se atribuye al Parlamento foral (y tampoco a las Cortes Generales), sino sólo al gobierno autónomo (Diputación foral) y al gobierno de la nación (artículo 71 de la Ley) que, además, deberán acordarla ("negociarla") de común acuerdo. Se trata, pues, de una propuesta de iniciativa, necesariamente pactada, que después se eleva a la cámara legisla- 
Este libro forma parte del acervo de la Biblioteca Jurídica Virtual del Instituto de Investigaciones Jurídicas de la UNAM

tiva autónoma para su aprobación (no para su probable enmienda también, como en las demás Comunidades), de tal manera (artículo 152 del reglamento parlamentario navarro) que el texto se somete a un único debate de totalidad y a una votación de conjunto, y si se supera se envía a las Cortes Generales (ejerciéndose, en ese momento, la verdadera iniciativa). El carácter pactado de la iniciativa (o mejor dicho, el carácter de pacto "entre gobierno" de la propuesta de iniciativa) se corresponde con el carácter pactado de la misma reforma, explícito en el artículo 71 de la Ley: "Dada la naturaleza jurídica del régimen foral, el Amejoramiento al que se refiere la presente Ley Orgánica es inmodificable unilateralmente".

\section{B. Iniciativa del gobierno de la nación y de las Cortes Generales}

Salvo en Navarra, donde la iniciativa se atribuye, como se ha visto, al gobierno y no a las Cortes y en Madrid, donde la iniciativa (asombrosamente) no se atribuye a ninguno de los dos órganos constitucionales (sólo se concede al gobierno y Parlamento autónomos y a dos tercios de los municipios), en todas las demás Comunidades, la propuesta de reforma puede efectuarla las Cortes Generales y en algunas de ellas (Asturias, La Rioja, Murcia, Castilla-La Mancha, Navarra y Baleares) también el gobierno de la nación.

Entre los muchos problemas que esta iniciativa plantea (me refiero sólo a los problemas de la iniciativa y no a los que afectan al resto del procedimiento de reforma, y por ello no he hablado de los que existen, y de bastante entidad, para la tramitación en las Cortes de las iniciativas de reforma procedentes de los órganos de la Comunidad), hay uno extraordinariamente complicado: el de la relación Cortes-Parlamento autónomos en el ejercicio de dicha iniciativa. Intentaré explicarme.

El reglamento del Congreso es sumamente parco en la materia, a la que dedica un solo artículo (el 145) en el que se dice que "la reforma de un Estatuto de Autonomía, tramitada con- 
Este libro forma parte del acervo de la Biblioteca Jurídica Virtual del Instituto de Investigaciones Jurídicas de la UNAM

forme a las normas en el mismo establecidas, requerirá aprobación mediante ley orgánica". ¿Ha de sujetarse la iniciativa del gobierno estatal y de las Cortes a las normas estatutarias en cuanto a su ejercicio? ¿O por el contrario, ha de adecuarse a lo que la Constitución y los reglamentos del Congreso y del Senado establecen para la iniciativa legislativa en general? La cuestión no es baladí, porque en los Estatutos se ordena, sin matización alguna a este respecto, que el proyecto de reforma deberá ser aprobado por el Parlamento propio. ¿Significa ello que el proyecto elaborado por el gobierno de la nación ha de ser remitido no al Congreso, sino al Parlamento autónomo, o la proposición de ley del Congreso o del Senado, después de su toma en consideración, no puede continuar el proceso legislativo en las Cortes Generales, sino que debe ser remitida también al Parlamento autónomo, que en ambos casos ha de debatir y aprobar o no tales iniciativas? Ello, además de subvertir totalmente el procedimiento parlamentario estatal (y chocar con preceptos de la Constitución y de los reglamentos del Congreso y del Senado) convertiría a la iniciativa del gobierno y de las Cortes Generales en mera "propuesta" de iniciativa, sometida a la voluntad posterior de las cámaras autonómicas que son las que ejercerían la auténtica iniciativa al aprobar los textos, aprobación que sería, paradójicamente, a su vez, una iniciativa ante las Cortes Generales que tienen que aprobar, finalmente, la reforma estatutaria. Como se ve, aparte de un galimatías, el sistema estaría plagado de incongruencias.

Ha de interpretarse, pues, que lo que los Parlamentos autónomos deben aprobar son las propuestas de reforma surgidas en el seno de la comunidad, no las que provengan (con la única excepción del caso de Navarra) del gobierno estatal o de las Cortes Generales, que siguen el curso propio de las iniciativas para la reforma de leyes estatales, sin participación, en esos supuestos, de los Parlamentos autónomos (aunque sí con el referéndum cuando es preceptivo para la reforma estatutaria). Esa me parece que es la interpretación correcta al del significado de los órganos gene- 
Este libro forma parte del acervo de la Biblioteca Jurídica Virtual del Instituto de Investigaciones Jurídicas de la UNAM

rales del Estado que gobierno y Cortes poseen, así como de la naturaleza jurídica de los propios Estatutos. ${ }^{74}$

De todos modos, no puede dejar de señalarse que la iniciativa para la reforma de los Estatutos refleja la situación en que se encuentra el propio sistema de reforma estatutaria, sistema extraordinariamente complicado, lleno de ambigüedades, incluso de contradicciones y lagunas, con un alto índice de heterogeneidad entre las diversas comunidades y muy necesitado de aclaraciones normativas y doctrinales.

\section{CONCLUSIONES}

Una vez examinados algunos de los problemas que plantean las diversas modalidades de iniciativa legislativa (no he dedicado una atención específica a la iniciativa para la reforma constitucional porque el supuesto se incluye, sin grandes problemas, en las vías previstas en el artículo 87.1 y apartado 2 de la $\mathrm{CE}$ ), me parece que debo concluir afirmando la conveniencia de distinguir, como he venido poniendo de manifiesto a lo largo de este capítulo, iniciativa de propuesta de iniciativa.

Tal distinción se deriva, sin duda, de nuestro ordenamiento constitucional y resulta congruente tanto con la forma de Estado

74 Con posterioridad a la publicación de este trabajo, he rectificado mi opinión en este punto, pues si bien hay razones para apoyar, con serios argumentos teórico-constitucionales e histórico-constitucionales (basados estos últimos en los precedentes sobre la reforma de los Estatutos catalán y vasco en la II República), la solución que aquí se sostiene, son de mayor peso los argumentos que conducen a entender que la iniciativa de las Cortes en la reforma estatutaria es, en realidad, una "propuesta" de iniciativa que habrá de ser presentada, necesariamente, en el Parlamento autonómico para que éste libremente la acepte (convirtiéndose entonces en iniciativa de ese Parlamento) o la rechace. Dicho cambio de criterio lo reconocí expresamente en mi trabajo "La iniciativa de las Cortes Generales en la reforma de los Estatutos de autonomía", Anuario de Derecho Constitucional y Parlamentario, Murcia, núm. 2, 1990, p. 34, Respecto de las razones en que se apoya ese cambio de criterio (sobre un asunto que no es nada simple, por cierto), me remito al aludido trabajo, donde se exponen con amplitud (pp. 33-41). 
Este libro forma parte del acervo de la Biblioteca Jurídica Virtual del Instituto de Investigaciones Jurídicas de la UNAM

que allí se establece, como con la forma de gobierno que el actual parlamentarismo racionalizado ha adoptado en España, pues, atribuyéndose la propuesta de iniciativa a los parlamentarios, a los ministros, a las Asambleas legislativas de las comunidades autónomas y a una fracción del cuerpo electoral, se atribuye, en cambio, la iniciativa propiamente dicha a órganos generales del Estado, que son, en consecuencia, los únicos capaces de imponer que un proyecto de norma pase en el Parlamento a la fase de deliberación y enmienda conservando, además, tales órganos, el derecho a retirarlo. Y ello es así para todas las leyes estatales, con la excepción, ya comentada (y creo que explicada) de los Estatutos de autonomía. En nuestro Estado compuesto, las leyes generales (generales en todos sus sentidos); es decir, las leyes estatales (con la salvedad, insisto, de los Estatutos) son iniciados por órganos generales y no por órganos parciales o fracciones de órganos. Cosa distinta es que estos órganos o fracciones tengan atribuidas facultades de propuesta de iniciativa; esto es, capacidad para instar a que la iniciativa se adopte, o si se quiere, participación en la preparación de la iniciativa misma.

La distinción no sólo me parece obligada, sino también saludable para nuestro sistema de producción normativa. Creo que algunas veces se ha pretendido, sobre la cuestión, suscitar en España un problema inexistente haciéndole decir a la Constitución lo que no dice. La Constitución habla, en el artículo 87.1, de "iniciativa legislativa" del gobierno, del Congreso y del Senado, y no de los miembros de estos órganos, y en el artículo 87.2 no dice "iniciativa", sino propuesta o capacidad de proponer. Me parece que a ello nos debemos atener, con lo que nos evitamos, además (afortunadamente, por obra del propio tenor literal de nuestra Constitución), los múltiples problemas teóricos y prácticos que en otros países existen (por ejemplo, en Italia) como consecuencia de que la iniciativa legislativa no esté atribuida a las cámaras, sino a los parlamentarios. 


\section{SOBRE EL SIGNIFICADO ACTUAL DEL PARLAMENTO Y DEL GONTROL PARLAMENTARIO: INFORMACIÓN PARLAMENTARIA Y FUNGIÓN DE CONTROL}

\section{INTRODUCGIÓN}

Para contribuir a un debate sobre los instrumentos de información de las Asambleas parlamentarias, me parece que quizá tendría sentido dedicar este trabajo a tratar ese asunto desde un marco más general, como es el del control parlamentario. Ello, porque la información en el Parlamento sólo alcanza su más profundo sentido en cuanto que es un medio (indispensable) para el ejercicio del control parlamentario. La información parlamentaria no tiene por finalidad genuina saciar el afán de conocimiento (o la simple curiosidad) de los miembros de las cámaras, sino suministrar la base necesaria para que el control parlamentario sea una realidad y no una apariencia. Sin información, claro está, se hace muy difícil que pueda haber control.

Es cierto que el Parlamento, en cuanto única institución representativa de todos los ciudadanos (y no sólo de la mayoría), tiene derecho a conocer todo lo "público", es decir, todo lo que afecte al interés general (utilizo el término "derecho", aunque sea impropio, porque es más comprensivo que el de "competencia”, que está relacionado con una dimensión menor que la institucional, como es la orgánica). Esa legitimación para conocer, sin embargo, alcanza su verdadero significado cuando no se agota en sí misma (al contrario de lo que ocurre con los derechos en sentido estricto, esto es, con los derechos de las personas, cuya 
Este libro forma parte del acervo de la Biblioteca Jurídica Virtual del Instituto de Investigaciones Jurídicas de la UNAM

dimensión subjetiva es insoslayable), sino cuando se entronca con la función a cuyo servicio está. Trasladando la terminología utilizada en el derecho de información (y en general en los derechos) de los ciudadanos, puede decirse que aquí el verdadero significado del "derecho" de información de las cámaras (al fin y al cabo, de los parlamentarios), sería la objetiva o funcional. La información parlamentaria adquiere todo su sentido en conexión con el fin a que está destinada: el debate con publicidad, es decir, el control.

De lo que acabo de decir se desprende, claro está, una determinada concepción del control parlamentario. También la necesidad de enfrentarse con el problema general de ese control en nuestro Parlamento al objeto de comprender mejor la situación actual (tanto en los aspectos positivos como en los negativos de sus posibles carencias, por falta de uso o falta de medios) de los instrumentos de información a disposición de las Cortes Generales. Por otro lado, el control parlamentario no puede desligarse del marco aún más general en que se inserta: el del funcionamiento de nuestra forma de gobierno. Por ello, este capítulo habrá de referirse también, aunque sea de manera sintética, a la práctica de nuestro parlamentarismo.

Sobre esa variedad de problemas (tan entrelazados) se intentará tratar, pues, en las páginas que siguen, en parte de las cuales lo que habrá, realmente, es una reiteración (a veces de manera incluso literal) de lo que ya he expuesto en publicaciones anteriores (especialmente en mis trabajos "El control parlamentario como control político" y "Gobierno y cortes"). La reiteración, allí donde se dé, no puedo evitarla, aunque sólo sea por tres razones: porque de estos mismos problemas me he venido ocupando desde hace tiempo, porque tales problemas siguen estando vivos y porque no he cambiado de opinión sobre los mismos. 
Este libro forma parte del acervo de la Biblioteca Jurídica Virtual del Instituto de Investigaciones Jurídicas de la UNAM

\section{ALGUNAS GONSIDERAGIONES GRÍTICAS SOBRE LA PRÁCTICA DE NUESTRA FORMA PARLAMENTARIA DE GOBIERNO}

Quizá convenga, ante todo, aclarar la posición desde la que examinaré la práctica de nuestra forma parlamentaria de gobierno. Carece de sentido, me parece, enjuiciar el funcionamiento actual de nuestro parlamentarismo (de cualquier parlamentarismo, incluso) a partir de aquel modelo ideal del parlamentarismo clásico que partía del supuesto de unas cámaras formadas por individuos enteramente libres a la hora de debatir y de votar, y que concebía al Ejecutivo como una especie de comité del Parlamento enteramente sometido a las instrucciones de éste, que podía revocarlo en cualquier momento. Es muy dudoso que ese modelo haya existido en cualquier momento del pasado (aun en los casos que más se le aproximaron, como fueron el de la III República francesa o el de la Alemania de Weimar), puesto que los intereses, la ideología, las "amistades políticas", etcétera, han operado siempre en las cámaras imponiendo cierta disciplina a los parlamentarios.

De todos modos, lo que no es dudoso es que en el presente tal modelo es absolutamente irreal, no sólo por la introducción en las Constituciones (en algunas de ellas) de reglas destinadas a favorecer la estabilidad de los gobiernos (lo que se ha llamado el "parlamentarismo racionalizado"), sino, sobre todo, por la radical transformación operada en el sistema de relaciones Parlamento-gobierno merced a la "democracia de partidos".

Hoy los agentes principales de la actividad de las cámaras no son los parlamentarios individuales sino los partidos políticos. La disciplina de partido y su proyección parlamentaria: la disciplina de grupo, hace muy difícil la remoción del gobierno por la cámara. Las votaciones parlamentarias están predeterminadas y, en consecuencia, la vieja idea (en que se sustentaba el parlamentarismo clásico) de la subordinación política del gobierno al Parlamento está, en el presente, muy alejada de la realidad. Hasta el punto de que se ha dicho que hoy, en realidad, el Parlamento es el comité Legislativo del gobierno. 
Este libro forma parte del acervo de la Biblioteca Jurídica Virtual del Instituto de Investigaciones Jurídicas de la UNAM

Todo ello es así, en sus líneas fundamentales, no cabe negarlo, pero, al mismo tiempo, tampoco es conveniente volver a caer en el error de construir un nuevo modelo del parlamentarismo del presente, radicalmente opuesto al antiguo y clásico, y que viniese a retratar no el funcionamiento normal de la forma parlamentaria de gobierno sino su patología; patología que en el pasado pudo ser el "parlamentarismo de Asamblea" y hoy el "parlamentarismo del Estado de partidos". El exceso de rigidez y disciplina que los partidos han introducido en las cámaras hasta el punto de que éstas hayan perdido su función central en el sistema, el alejamiento entre los representados y sus representantes, la atonía de la vida parlamentaria, sustituida por el protagonismo de los jueces y de los medios de comunicación, la absoluta prevalencia, en fin, de un poder del Estado (el gobierno) sobre otro (el Parlamento) no es el fiel retrato del parlamentarismo de nuestro tiempo, sino la imagen de un tipo de parlamentarismo enfermizo que sólo se ha producido en algunos países (especialmente del sur de Europa) y que, por ello, más que al parlamentarismo lo que muestra es a su caricatura.

Es cierto que hoy, gracias a la disciplina de partido, los Parlamentos están razonablemente organizados y los gobiernos disfrutan de una estabilidad también razonable. Ello es conveniente y además viene exigido por los mismos ciudadanos, que desean gobiernos eficaces, aparte de ser congruente con los principios constitucionales en que el sistema descansa y que imponen la necesidad de que la mayoría pueda llevar a cabo su programa electoral. Ahora bien, ello no tiene por qué conducir necesariamente a la práctica desaparición del control parlamentario, a la pérdida de protagonismo de las cámaras y a la virtual erradicación de la división de poderes. La forma parlamentaria de gobierno, creación de la historia constitucional británica, descansa en un sistema de equilibrios, de frenos y contrapesos que resultan incompatibles con la radical hegemonía de un poder sobre otro. Su correcto funcionamiento ni ha sido una excepción en el pasado ni lo es en el presente: ahí están los ejemplos de las 
Este libro forma parte del acervo de la Biblioteca Jurídica Virtual del Instituto de Investigaciones Jurídicas de la UNAM

seculares monarquías parlamentarias europeas para demostrarlo. Allí, la transformación de los Parlamentos de individuos en Parlamentos de partidos no ha conducido a la perversión del sistema, esto es, a la conversión del Parlamento en una institución sin relieve político propio, totalmente sometida a la voluntad del gobierno.

En España parece que estamos ante el riesgo de incurrir en aquella situación patológica a la que antes me refería, y no por obra, precisamente, de las normas constitucionales reguladoras de la forma de gobierno (que, salvo en lo que se refieren al Senado, proporcionan un esquema de parlamentarismo bastante razonable), sino de las normas infraconstitucionales y de la práctica política, que, de una parte, han acentuado, en exceso, las tendencias oligárquicas de los partidos y, de otra, han disminuido, también en exceso, la función parlamentaria de control.

España tiene unos partidos excesivamente burocratizados, que dejan muy escasa libertad de actuación a sus miembros. Además, el sistema electoral de listas cerradas y bloqueadas (obra de la Ley Electoral, que no de la Constitución) potencia la dominación del partido por sus dirigentes. Por otra parte, los reglamentos de las cámaras contribuyen a acentuar la dependencia de los parlamentarios respecto de sus correspondientes grupos, de tal manera que son los portavoces o presidentes de éstos los auténticos directores (o impulsores) de las actividades parlamentarias. En el seno de las relaciones Parlamento-gobierno se introduce, pues, una férrea estructura jerárquica que descansa en la subordinación del parlamentario individual a su jefe de grupo, en la de éste a su partido y en la del partido a su líder. Como el líder del partido mayoritario es a su vez el presidente del gobierno (y si no lo fuera daría igual, sólo ocurriría que el presidente del gobierno estaría subordinado al líder del partido, lo que ya sucede en alguna comunidad autónoma), éste ocupa la cúspide del poder: a él están subordinados el gobierno, el partido y el grupo parlamentario, esto es, a él está subordinada la voluntad del Ejecutivo y del Legislativo. 
Este libro forma parte del acervo de la Biblioteca Jurídica Virtual del Instituto de Investigaciones Jurídicas de la UNAM

Esta situación se afianza si a los factores ya aludidos se añade la realidad de unas elecciones, como las españolas (el fenómeno, claro está, no es exclusivo de nuestro país), que, por obra de una propaganda en la que predomina sobre todo la imagen, se manifiestan más como elecciones plebiscitarias que como elecciones representativas; es decir, como elecciones no tanto a diputados o senadores cuanto a presidente del gobierno. Los aspirantes a parlamentarios que componen las listas electorales quedan en muy segundo plano, puede decirse incluso que se difuminan, máxime cuando la relación de los candidatos con la circunscripción en la que se presentan o no existe o juega muy escaso papel. Celebradas las elecciones y constituidas las nuevas cámaras, los parlamentarios continúan virtualmente en el anonimato: la suerte del gobierno, las leyes que se dicten, los presupuestos que se aprueben, no van a depender ni de sus discursos ni de sus decisiones, sino de los jefes de sus respectivos grupos políticos, que serán los que actúen en los principales debates parlamentarios y los que les impartan instrucciones para votar de una u otra manera.

Ahora bien, la difuminación de los parlamentarios individuales no tendría por qué conducir, necesariamente, a la difuminación del Parlamento; sólo llevaría a un Parlamento oficialmente numeroso pero virtualmente reducido: un Parlamento de jefes de grupo, es decir, un Parlamento de "portavoces". Ocurre, sin embargo, que la forma en que están organizados en nuestro país los debates parlamentarios contribuye a que incluso ese Parlamento reducido continúe difuminado. De un lado, el presidente del gobierno no interviene ordinariamente en los debates (ni acude cotidianamente a la cámara), reservándose para las grandes ocasiones. De otro, los debates se celebran con muy escasa vivacidad: los miembros del gobierno y los portavoces de los grupos ocupan, sucesivamente, la tarima de oradores y leen (muy pocas veces improvisan) sus discursos preparados. Por último, los problemas políticos importantes no suelen ser tratados, de inmediato, en el Parlamento, con el consiguiente desprestigio de éste. A todo ello ha de añadirse la tendencia a "consensuar" las grandes decisiones (incluidas las que 
Este libro forma parte del acervo de la Biblioteca Jurídica Virtual del Instituto de Investigaciones Jurídicas de la UNAM

han de revestir forma de ley) con los llamados "protagonistas sociales", utilizándose muchas veces a las cámaras como órganos de mera ratificación de lo ya acordado fuera de ellas.

Es cierto que el Parlamento español trabaja y que es una imagen muy poco fidedigna de la actividad parlamentaria la que a veces se propaga con ocasión de una eventual sesión en que aparezcan vacíos la mayoría de los escaños. Se presentan infinidad de preguntas, numerosas interpelaciones, se preparan proposiciones de ley (aunque la mayor parte estén condenadas a no prosperar), se hacen y discuten enmiendas a los proyectos de ley presentados por el gobierno, hay un quehacer continuo en ponencias y comisiones. En esas tareas desempeñan un gran papel los parlamentarios individuales. También hay que destacar (sería injusto silenciarlo) la importante actividad informativa y de debate que se desarrolla con ocasión de las frecuentes comparecencias de los ministros en las comisiones parlamentarias. Pero todo ello trasciende muy poco a la opinión pública, que sólo recibe del Congreso y del Senado las imágenes que transmiten sus plenos. Y no podría ser de otra manera, ya que a los ciudadanos más que las cuestiones técnicas lo que les interesa son los auténticos problemas políticos, esto es, los que, por su propia naturaleza, debieran tratarse en el pleno de las cámaras.

La falta de protagonismo del Parlamento provoca un vacío en la vida democrática de un país que suele ser llenado por otras instituciones: especialmente por los medios de comunicación y por la judicatura. No se trata, en modo alguno, de que estos nuevos protagonistas vengan a invadir campos que no son suyos. Una sociedad democrática no puede existir sin una prensa libre, se decía hace ya más de un siglo; hoy podríamos añadir, ni sin una radio y una televisión libres. Un Estado de derecho no lo es tal sin control jurisdiccional. El problema surge cuando el control social y el control jurisdiccional del poder han de sustituir, casi enteramente, al control parlamentario. En ese caso los ciudadanos tienen muy poco que ganar y la democracia parlamentaria mucho que perder. 
Este libro forma parte del acervo de la Biblioteca Jurídica Virtual del Instituto de Investigaciones Jurídicas de la UNAM

\section{LA TENTAGIÓN PRESIDENGIALISTA DE NUESTRO}

\section{PARLAMENTARISMO}

Podría pensarse, sin embargo, que el enjuiciamiento que acaba de hacerse sería errado, en cuanto que no se estaría ante una situación patológica, esto es, ante una perversión del sistema parlamentario, sino ante la realidad de un sistema nuevo, que muy poco tendría ya que ver con el parlamentarismo. Así, cabría argüir que esta práctica política de la forma parlamentaria de gobierno no tiene consecuencias negativas, necesariamente, sino que en realidad lo que supone es la transformación del sistema, que de parlamentario habría pasado a ser presidencial, produciéndose una especie de mutación constitucional mediante la cual, sin cambiar la letra de la Constitución y por obra de la práctica política, tendríamos en España una forma de gobierno más próxima a la de los Estados Unidos de América que a la del Reino Unido (que siempre ha sido el modelo de la monarquía parlamentaria).

Nuestro presidente del gobierno disfrutaría, igual que el presidente norteamericano, de una legitimación democrática directa, pues al fin y al cabo nuestras elecciones, formalmente parlamentarias, son realmente presidencialistas. Que no responda, de facto, un presidente así (ni "su” gobierno, y aquí aparece otra analogía con el modelo norteamericano) ante el Parlamento es lo que ocurre en el modelo presidencial, y ello no significa que ese modelo no sea democrático: al fin y al cabo el presidente responde ante el pueblo, que lo elige. Que el presidente comparezca poco ante el Parlamento también sería normal, en los Estados Unidos sólo va a la cámara para pronunciar el discurso anual sobre "el estado de la Unión" (aquí, y otra vez más surge la analogía, ya está importada la figura: el debate sobre "el estado de la nación").

Ahora bien, un diagnóstico así sería sumamente engañoso. En primer lugar por los impedimentos constitucionales con que tropezaría, ya que el sistema presidencial y el monárquico son difíciles de conjugar. Un presidente de gobierno con legitimación democrática directa tendería, por la fuerza de las cosas, a des- 
Este libro forma parte del acervo de la Biblioteca Jurídica Virtual del Instituto de Investigaciones Jurídicas de la UNAM

plazar excesivamente al jefe del Estado, que tiene unas funciones constitucionalmente establecidas y cuyo encaje, con un Ejecutivo elegido por el pueblo, podría resultar muy problemático. No en vano la jefatura del Estado hereditaria ha podido subsistir en el Estado democrático entre otras razones porque se ha residenciado en el Parlamento, y no en el gobierno, la representación popular, esto es, en la medida en que la monarquía es "parlamentaria".

Pero, aparte de ello, el diagnóstico seguiría siendo engañoso en cuanto que tampoco se correspondería con la realidad, pues no es cierto que, pese a los obstáculos teóricos antes expuestos, la práctica haya conducido a un sistema presidencial. Ese sistema se basa en la separación de poderes; la práctica política que se ha descrito lleva a lo contrario: a la confusión entre Parlamento y gobierno; es decir, a la unidad del poder "político", del que estaría separado sólo el poder jurisdiccional. En un sistema presidencial, los ciudadanos eligen al Parlamento, y en otra elección bien distinta al presidente, con la consecuencia de que, al recibir ambas instituciones de manera independiente la legitimación popular, la coincidencia partidista entre mayoría parlamentaria y presidente no tiene por qué darse, necesariamente; esa coincidencia, en cambio, es requisito del sistema parlamentario. Pero como la práctica política ha hecho que en este sistema no sea el gobierno el que esté sometido a la mayoría parlamentaria, sino ésta la que esté dirigida por aquél, se da la paradoja de que, en una estructura constitucional, como la presidencial, no basada, por principio, en la relación de confianza entre Legislativo y Ejecutivo, puede haber (y lo hay, de hecho, al menos en el caso norteamericano) mayor control parlamentario del gobierno que en aquel otro sistema teóricamente sustentado en la confianza y el control. En España el presidente compone libremente "su" gobierno; en los Estados Unidos de América los secretarios de los departamentos (y otros altos cargos, entre ellos los embajadores) los designa el presidente, pero no libremente, ya que tales nombramientos requieren de la aprobación del Senado. Si la com- 
Este libro forma parte del acervo de la Biblioteca Jurídica Virtual del Instituto de Investigaciones Jurídicas de la UNAM

paración la extendemos al control presupuestario y a la eficacia de las comisiones parlamentarias de investigación, la diferencia se acrecienta aún más, en favor del sistema norteamericano y en detrimento del nuestro.

En resumen, nuestra práctica política de la forma parlamentaria de gobierno no parece que haya originado su mutación en una forma presidencial, sino más bien su transformación en un híbrido en el que se reúnen muchos de los inconvenientes de aquellos dos sistemas y muy pocas de sus ventajas. El resultado es una mezcla de presidencialismo incompleto y de parlamentarismo distorsionado; es decir, una amalgama que produce el debilitamiento de la división de poderes y la correspondiente atonía de la democracia parlamentaria como forma de organización política.

\section{LA FUNGIÓN DEL GOBIERNO Y LA FUNCIÓN Del PARlamento. LOS Rasgos ESENGIALES DE NUESTRA FORMA DE GOBIERNO}

Por todo lo que he dicho anteriormente, mantengo la valoración que la práctica de nuestra forma parlamentaria de gobierno merece: creo que esa práctica está incurriendo en defectos que pueden llevar a nuestro sistema al riesgo de una crisis, riesgo que convendría atajar cuanto antes. La solución para superar esos problemas no parece, sin embargo, que resida en acentuar los rasgos presidenciales que la práctica ha venido imponiendo, sino en fortalecer los rasgos parlamentarios que esa práctica ha ido debilitando.

Fortalecer los rasgos parlamentarios no significa, por supuesto, debilitar al gobierno, sino acentuar su control. Tampoco significa exigir del Parlamento lo que éste, hoy, de ninguna manera, puede dar. Por ello, en el presente, conviene aclarar cuáles son las funciones de uno y otro órgano.

Por obra de una diversidad de causas bien conocidas y que han originado la transformación del Estado liberal del siglo XIX en el Estado social y democrático actual, ni el Parlamento 
Este libro forma parte del acervo de la Biblioteca Jurídica Virtual del Instituto de Investigaciones Jurídicas de la UNAM

es ya el poder de dirección ni el gobierno el de mera ejecución. Ahora el reparto esencial de las funciones políticas del Estado es bien distinto: el gobierno dirige la política y el Parlamento la controla. Nuestra Constitución incluso lo reconoce así expresamente al atribuir al gobierno la función de "dirección política" (el gobierno "dirige la política interior y exterior", artículo 97 de la CE) y al Parlamento, la función de control (las Cortes Generales "controlan la acción del Gobierno", artículo 66.2 de la CE).

Desde esta perspectiva resulta congruente que en las elecciones se voten programas de gobierno y que, de acuerdo con los resultados electorales, sea el gobierno y no el Parlamento el que dirija la realización de dicho programa. Si ocurriese que la mayoría del Parlamento dejase de estar conforme con el programa gubernamental, lo que procede (lo que el sistema reclama) es el cambio de gobierno y no la imposición a éste, por el Parlamento, de una política distinta a la suya. Sin embargo, la configuración "constructiva" de la moción de censura hace muy difícil esa solución y, por otro lado, la exigencia de mayoría absoluta en el Congreso para la aprobación de las leyes orgánicas contribuye a aumentar el problema.

En resumen, nuestro "parlamentarismo racionalizado" facilita la estabilidad de los gobiernos de minoría, pero también exige que sea el gobierno el que dirija la política, esto es, el que realice, en la legislatura, su programa; pero la realización de un programa de gobierno difícilmente puede llevarse a cabo en minoría (y no sólo respecto de las materias propias de ley orgánica, aunque en éstas con mayor motivo).

El dilema que entonces se plantea es: o gran parte de la política se hace por consenso o se gobierna apoyado en una mayoría absoluta. La primera solución no parece recomendable, primero, porque no sería la querida por la Constitución (una política de consenso no es, por principio, una política dirigida por el gobierno, si es que el consenso es auténtico y no significa la mera aceptación por unos de lo ya decidido por otros), y, segundo, porque significaría sustraer al pluralismo político una buena parte de la 
Este libro forma parte del acervo de la Biblioteca Jurídica Virtual del Instituto de Investigaciones Jurídicas de la UNAM

política nacional. El consenso ya lo exige la Constitución (mayorías de tres quintos o superiores) para las grandes decisiones estatales (composición de órganos constitucionales y reforma de la Constitución) y no sería conveniente (entre otras cosas porque se defraudaría el significado de las elecciones pluralistas) extenderlo mucho más. Por ello, es la segunda alternativa la que parece más correcta, dándose, pues, la paradoja de que nuestra Constitución, que facilita los gobiernos de minoría, requiere, al mismo tiempo, una mayoría parlamentaria para poder gobernar. El sistema, en consecuencia, conduce a que, si un partido no obtiene la mayoría absoluta, deba formarse un gobierno de coalición (mejor que un pacto de legislatura) si es que se quiere cumplir con las exigencias del propio sistema, es decir, con que la política se dirija desde el gobierno y no desde el Parlamento.

Al Parlamento le corresponde un papel bien distinto, pero no menos importante: controlar la política gubernamental. Es cierto que al Parlamento también le está atribuida, constitucionalmente, la potestad legislativa, a cuyo través se adopta el indirizzo político estatal en su máxima expresión. Pero también es cierto que la relación estabilizada (y conveniente) entre gobierno y mayoría parlamentaria hace que la creación de la ley haya de obedecer más a los designios del gobierno que a la voluntad independiente del Parlamento. Además, por exigencias no sólo de la práctica, sino también de la teoría (más aún, de la norma constitucional), es congruente que ello sea así, pues al gobierno le compete la dirección de la política y ello significa, sin duda, la dirección de la "política legislativa", puesto que es a través de ella como puede realizar su programa. De ahí que, sin negar la superior importancia de la potestad legislativa desde la perspectiva del conjunto de las potestades estatales, quepa sostener, desde una perspectiva exclusivamente parlamentaria, que la función más relevante que hoy cualifica al Parlamento del presente es, con seguridad, la función de control, en cuanto que a través de ella puede la cámara desempeñar un papel por sí misma sin 
Este libro forma parte del acervo de la Biblioteca Jurídica Virtual del Instituto de Investigaciones Jurídicas de la UNAM

la mediación gubernamental, esto es, apareciendo como institución distinta (e independiente) del gobierno.

Además, esa función es la que podría considerarse, sin exageración alguna, como la "genuina" de la cámara, la más propia de su naturaleza, puesto que, sin perjuicio de que el Parlamento pueda (y deba) decidir, el Parlamento está, sobre todo (de otra manera no se entendería ni siquiera su misma estructura), para discutir. Esta es (la de debatir, es decir, la de controlar) la función primordial que nuestro Parlamento debe cumplir y que ahora no la realiza con plenitud: de una parte porque no ejercita debidamente los instrumentos de control que posee, de otra, porque carece de algunos instrumentos indispensables de control y, finalmente, porque hay sectores de la política que no están siendo objeto de suficiente control parlamentario. Antes de examinar esas tres carencias conviene, no obstante, aclarar el significado del control parlamentario, para evitar fáciles, aunque frecuentes, confusiones.

\section{EL SIGNIFICADO ACTUAL DEL GONTROL PARLAMENTARIO}

El Estado constitucional se basa no sólo en la división de poderes, sino también en el equilibrio entre ellos, esto es, en la existencia de una extensa red de controles (jurisdiccionales, políticos y sociales) que impidan el ejercicio ilimitado e irresponsable de la autoridad. El control parlamentario es uno de esos controles: un control de carácter político cuyo agente es el Parlamento y cuyo objeto es la acción del gobierno y, por extensión, también la acción de cualesquiera otras entidades públicas, excepto las incluidas en la esfera del poder jurisdiccional, que, por principio, es un poder que debe gozar de total independencia respecto de los demás poderes del Estado.

Ahora bien, cabría decir que existen dos significados del control parlamentario. Uno, al que podría llamarse significado estricto, consistiría en entender que el control parlamentario ha 
Este libro forma parte del acervo de la Biblioteca Jurídica Virtual del Instituto de Investigaciones Jurídicas de la UNAM

de incluir, necesariamente, la capacidad de remover al titular del órgano controlado; su ejercicio se llevaría a cabo mediante la votación de confianza y la moción de censura. Ni qué decir tiene que este significado resulta muy escasamente operativo. En primer lugar porque sólo podría hablarse de la existencia del control parlamentario en los países de forma parlamentaria de gobierno, pero no en los países de forma presidencial, pese a que en éstos el Parlamento desempeña una función innegable de contrapeso, de freno, de fiscalización, en suma, de la actividad gubernamental. En segundo lugar porque dada la disciplina de partido y el papel que hoy desempeñan los partidos en el Parlamento, el control, en los países de forma parlamentaria de gobierno, sería casi inexistente: se trataría o bien del control de la mayoría sobre sí misma o bien (y más exactamente) del control del gobierno sobre sí mismo; en definitiva, un autocontrol, que es lo contrario de un auténtico control, en cuanto que éste presupone la distinción real entre controlante y controlado. Más aún, ese control, además de su escasa operatividad, sólo podría efectuarse, en el caso de ciertos Parlamentos bicamerales, en la cámara a la que correspondiera la exigencia de la responsabilidad política, esto es, en el ejemplo español, en el Congreso de los Diputados y no en el Senado, cámara esta última que no podría realizar funciones de control parlamentario pese a que el artículo 66 de la CE atribuye esa función a las Cortes Generales (lo que quiere decir, sin duda alguna, a las dos cámaras que la componen).

Parece claro, en consecuencia, que ese significado estricto no resulta útil, debiendo acudirse a otro más amplio, que comprenda en el control parlamentario toda la actividad de las cámaras destinada a fiscalizar la acción del gobierno (o de otros entes públicos), lleve o no aparejada la posibilidad de sanción inmediata (esto es, de remoción de los titulares del órgano controlado). Es cierto que la derrota del gobierno es uno de los resultados que el control parlamentario puede alcanzar y el hecho de que hoy, por la disciplina de partido, eso sea muy poco probable no lo convierte por ello en un resultado imposible. Pero también es cierto que 
Este libro forma parte del acervo de la Biblioteca Jurídica Virtual del Instituto de Investigaciones Jurídicas de la UNAM

muy escaso papel tendría esta función parlamentaria de control si sólo se manifestase a través de la remota posibilidad de que el gobierno perdiese la confianza de la cámara o si requiriese, para ser efectiva, de la fractura del partido o partidos que forman la mayoría gubernamental.

Además, la derrota del gobierno, siendo uno (el más fuerte, sin duda) de los efectos del control parlamentario, ni es el único ni el más común. De una parte, el control parlamentario existe en la forma de gobierno presidencial en la que no es posible la exigencia de la responsabilidad política (el impeachment es cosa bien distinta: no tiene por objeto la exigencia de responsabilidad política sino de responsabilidad penal); y, ello es así, porque el control parlamentario no es privativo de la forma parlamentaria de gobierno, sino de la democracia parlamentaria como forma de Estado. De otra parte, en los regímenes parlamentarios, en los que la responsabilidad política es posible en teoría, aunque improbable en la práctica, la fiscalización parlamentaria del gobierno se manifiesta por otras muchas vías, aparte de por las que pudieran conducir a su remoción.

La eficacia del control parlamentario no descansa sólo en la sanción directa, sino también en la sanción indirecta, no sólo en la obstaculización inmediata, sino también en la capacidad de crear o fomentar obstaculizaciones futuras, no sólo, pues, en derrocar al gobierno o, sin llegar a ello, en corregir sus propuestas, sino también en desgastarlo o en contribuir a su remoción por el cuerpo electoral. Esta labor de fiscalización, que el Parlamento realiza (o debe realizar) de manera ordinaria y cotidiana, y que no tiene por objeto derrotar al gobierno (pretensión difícil de cumplir) pero sí criticarlo, constituye, sin duda alguna, una de las dimensiones más importantes del control parlamentario.

Entendido así, el control parlamentario ni siquiera se circunscribe a unos determinados procedimientos, sino que puede operar a través de todas las funciones que desempeñan las cámaras. No sólo, pues, en las preguntas, interpelaciones, mociones, comisiones de investigación, control de normas legislativas del 
Este libro forma parte del acervo de la Biblioteca Jurídica Virtual del Instituto de Investigaciones Jurídicas de la UNAM

gobierno (instrumentos más característicos del control) se realiza la función fiscalizadora, sino también en el procedimiento legislativo (crítica al proyecto presentado, defensa de enmiendas, etcétera), en los actos de aprobación o autorización, de nombramiento o elección de personas y, en general, en la total actividad parlamentaria. En todos esos casos hay (o debe haber) debate y, en consecuencia, en todos hay (o puede haber) control parlamentario.

Por ello, para comprender mejor el significado actual del control parlamentario (comprensión sin la cual difícilmente puede mejorarse, con realismo, su eficacia), conviene distinguir entre el control "por" el Parlamento y el control "en" el Parlamento. En el primer supuesto, el control se lleva a cabo mediante actos que expresan la voluntad de la cámara; en el segundo, a través de las actividades de los parlamentarios individuales o los grupos parlamentarios desarrolladas en la cámara, aunque no culminen en un acto de control adoptado por ésta. En este último caso, aunque no se produzca una decisión de la cámara con efectos negativos para el gobierno, no deja de haber control parlamentario, en la medida en que la discusión parlamentaria influye en la opinión pública; el Parlamento, entonces, es el locus de donde parte el control, pero la sociedad es el locus al que principalmente se dirige, puesto que es allí (y no en la propia cámara) donde pueden operar sus más importantes efectos.

De esa manera, el control parlamentario puede manifestarse, por supuesto, a través de decisiones de la cámara (adoptadas en el procedimiento legislativo, en actos de aprobación o autorización o en mociones) que son, inevitablemente, decisiones de la mayoría, porque así se expresa (como es obvio) la voluntad del Parlamento; pero también el control puede manifestarse a través de actuaciones de los parlamentarios individuales o de los grupos parlamentarios (preguntas, interpelaciones, intervención en debates) que no expresan la voluntad de la cámara, pero cuya capacidad de fiscalización sobre el gobierno no cabe negar, bien porque pueden hacerlo rectificar, o al menos debilitarlo en sus posiciones, bien porque pueden incidir en el control social o en el 
Este libro forma parte del acervo de la Biblioteca Jurídica Virtual del Instituto de Investigaciones Jurídicas de la UNAM

control político electoral. Y esa labor fiscalizadora del gobierno, realizada no por la mayoría sino por la minoría, es, indudablemente, un modo de control parlamentario gracias a la publicidad y al debate que acompañan (o deben acompañar) a todas las actividades de la cámara. Aquí no hay, pues, control "por" el Parlamento (que sólo puede ejercitar la mayoría y que hoy, por razones bien conocidas a las que ya se aludió, es o puede ser relativamente ineficaz), pero sí control "en" el Parlamento: un control que no realiza la mayoría, sino, exactamente, la oposición.

Esa es la razón por la que ciertos medios de control debieran configurarse como derechos de las minorías, que pueden ser ejercitados incluso contra la voluntad de la mayoría (obtención de información, preguntas, interpelaciones, constitución de comisiones de investigación). Las minorías han de tener reconocido el derecho a debatir, criticar e investigar, aunque, como es lógico, la mayoría tenga al final la capacidad de decidir. Hoy ya no es la clásica contraposición gobierno-Parlamento la que resulta más relevante, sino la contraposición gobierno-oposición. Esta nueva contraposición no viene a sustituir enteramente a la vieja y clásica, ya que en la diferenciación entre Parlamento y gobierno y en la configuración jurídica de ambos como órganos distintos descansa la división de poderes, sin la cual no hay sistema constitucional digno de ese nombre, pero plantea determinadas exigencias, entre las que está la atribución de derechos de control a las minorías parlamentarias. El control "en" el Parlamento no sustituye, pues, al control "por" el Parlamento, pero hace del control una actividad de ordinario (mejor sería decir cotidiano) ejercicio en la cámara.

La distinción conceptual que se ha venido exponiendo, respecto del control parlamentario, corre paralela a otra distinción que, sobre el significado del propio Parlamento, conviene hacer, distinción que se basa en la diferencia entre el Parlamento como órgano y el Parlamento como institución. El Parlamento no es sólo un órgano del Estado que, como todo órgano colegiado, adopta sus decisiones por mayoría, sino que es también una insti- 
Este libro forma parte del acervo de la Biblioteca Jurídica Virtual del Instituto de Investigaciones Jurídicas de la UNAM

tución cuya significación compleja no puede quedar borrada por el artificio orgánico. Más aún, el Parlamento es la única institución del Estado donde está representada toda la sociedad y donde, en consecuencia, ha de expresarse y manifestarse frente a la opinión pública, a través del debate parlamentario, el pluralismo político democrático (es decir, la diversidad de voluntades presentes en la cámara y no sólo una de ellas, aunque sea mayoritaria).

Por ello, el control parlamentario no es eficaz sólo en cuanto permita la limitación del gobierno, sino también, y sobre todo, en cuanto permita que en la cámara se manifiesten la diversidad de voluntades que la componen, capaces de exponer sus programas alternativos y de debatir y criticar públicamente la actuación gubernamental. Esto es, en la medida en que el control se enlace con la dimensión institucional-pluralista del Parlamento. La mayoría puede frenar el control "por" el Parlamento, pero no puede, de ninguna manera (a menos que se destruya el presupuesto básico de la democracia representativa), frenar el control "en" el Parlamento. La mayoría tiene el derecho a decidir, pero las minorías han de tener el derecho a conocer y a discutir.

\section{AlgunAS PROPUESTAS DE REFORMA}

\section{Sobre los debates en la cámara y la comparecencia} del presidente del gobierno

A partir de este entendimiento del control parlamentario se comprenden mejor las debilidades que muestra ese control en nuestro Parlamento y las necesidades de introducir reformas que lo fortalezcan. Reformas encaminadas, en primer lugar, a agilizar los debates. Nuestra práctica parlamentaria está excesivamente lastrada por los discursos. Habría que evitar, en la medida de lo posible, que los sucesivos oradores subiesen al estrado con el correspondiente montón de folios dispuestos para su lectura. Incluso, podría ser saludable que el mismo estrado desapareciese y las intervenciones se hicieran desde el propio escaño, leyendo poco, 
Este libro forma parte del acervo de la Biblioteca Jurídica Virtual del Instituto de Investigaciones Jurídicas de la UNAM

si también es posible. Quizá esta modificación, tan drástica pueda ser una utopía, estando tan arraigada entre nosotros la práctica del estrado y de la lectura, cuyos orígenes se sitúan, desde luego, en las Cortes franquistas. Pero, al menos, podría introducirse una moderada corrección. En ese sentido, cabría reservar el podio a quien ejerza, en cada actividad parlamentaria, la iniciativa, es decir, al orador que represente al grupo u órgano que impulsa el debate; el resto de las intervenciones debieran hacerse desde el escaño, para discutir y no para "discursear", con tiempos breves, tasados, si hace falta, y con inmediatas réplicas y dúplicas. Hoy es cierto que, en la cámara, los parlamentarios hablan más para la opinión pública que para sus colegas, a los que difícilmente van a convencer en cuanto que sus votos están predeterminados, pero ello no aminora, sino que acrecienta, la necesidad de dotar de mayor vivacidad al debate. Sin que ello signifique, claro está, que se deba incurrir en ese tipo de discusiones caóticas y agresivas, frecuentes en otros tiempos (y todavía hoy, en algunos países), muy "folclóricas" (en el peor sentido de la expresión) pero muy poco favorecedoras de la dignidad de las cámaras y, por lo mismo, del respeto de éstas por la opinión pública. Nuestro Parlamento, por fortuna, es un Parlamento sosegado; de lo que se trata es que el sosiego no se confunda con el entumecimiento.

De todos modos, este cambio de "estilo" no sería suficiente; es preciso también un cambio de "presencia". Si la intervención del presidente del gobierno en el Congreso de los Diputados fuese más ordinaria o habitual (como requiere la Constitución al definir a nuestra forma de gobierno como parlamentaria y al atribuir la dirección de la política gubernamental al presidente del gobierno) y tuviesen lugar, por lo mismo, constantes debates (para eso, para debatir está esencialmente el Parlamento; para echar discursos están las academias; para adoptar decisiones bastaría con la Junta de portavoces) en la cámara sobre problemas concretos, tratados inmediatamente que se produzcan, el Parlamento, disfrutaría de mucho más relieve del que ahora tiene ante la opinión pública. Es cierto, como antes se señaló, que las fre- 
Este libro forma parte del acervo de la Biblioteca Jurídica Virtual del Instituto de Investigaciones Jurídicas de la UNAM

cuentes intervenciones de los ministros en las comisiones (y en el pleno) producen un saludable efecto en la vida de nuestras cámaras; pero tales intervenciones ni pueden sustituir, por razones obvias, a las del presidente del gobierno ni pueden desempeñar en el ámbito parlamentario, por lo mismo, la relevante función de liderazgo de la política estatal que en nuestro sistema sólo al presidente (y no a su gobierno) le está encomendada. Por ello, y sin perjuicio de las competencias de cada ministro sobre las materias de su departamento y del papel parlamentario que, respecto de las mismas, ha de desempeñar, le corresponde al presidente del gobierno pronunciarse en la cámara sobre todos los asuntos públicos que por su importancia y urgencia así lo demanden. Él dirige la política gubernamental y a él, al fin y al cabo (y no a sus ministros), otorgó en su día la cámara la confianza política que legitima la ocupación del cargo (y de la responsabilidad) que ostenta.

\section{Sobre la extensión material de las actividades de información}

y control: en especial, respecto de la política europea, la política autonómica y el sector "para-estatal"

Otro tipo de reformas tendría por objeto instaurar medios de control de los que ahora se carece; a fin de eliminar cualquier restricción a la plena capacidad del Parlamento para debatir e investigar. El principio de que en las cámaras no debe haber decisión sin previa discusión, conduce a que las designaciones que hace el Parlamento de titulares de otros órganos públicos deban estar precedidas de suficiente debate sobre los candidatos propuestos (lo que ahora no ocurre). El principio de que nada debe hurtarse al conocimiento parlamentario exige que la constitución de comisiones de investigación no quede en manos de la mayoría (como ahora ocurre), sino que se atribuya, como derecho, a las minorías.

Finalmente, para revitalizar nuestro parlamentarismo es necesario que no haya zonas de la política escasamente controladas 
Este libro forma parte del acervo de la Biblioteca Jurídica Virtual del Instituto de Investigaciones Jurídicas de la UNAM

en las cámaras, como ahora ocurre, de facto, con la política europea, la política autonómica y la actividad de ese amplio conglomerado de entes públicos (o de personificaciones instrumentales) que los politólogos llaman el "para-Estado" y que desarrolla sus cometidos al margen de la estructura orgánica, clásica, de la administración pública.

Sería un manifiesto error creer que porque gran parte de la política nacional se decida en las instancias comunitarias europeas, nuestro Parlamento carece de competencia para controlarla. Las decisiones comunitarias las adoptan los representantes de los gobiernos nacionales, y éstos han de dar cuenta de sus actuaciones ante sus respectivos Parlamentos. Resulta muy cómodo hablar del déficit democrático de la comunidad, cuando ocurre que gran parte de ese déficit se produce como consecuencia no sólo de la falta de poderes del Parlamento europeo, sino también de la falta de control de los Parlamentos nacionales sobre sus propios gobernantes (que son también gobernantes europeos). Afortunadamente, los nuevos vientos originados por el Tratado de la Unión Europea (y por la importante polémica constitucional que en algunos países ha generado, cuyo mejor ejemplo quizá se haya plasmado en la sentencia del 12 de octubre de 1993 del Tribunal Constitucional Federal alemán), parece que obligan a establecer con claridad y firmeza las correspondientes medidas en los Parlamentos nacionales para hacer efectivo el control, sobre sus respectivos gobiernos, de la política europea que llevan a cabo. Es de esperar que en España tales medidas se adopten cuanto antes.

Por lo que se refiere a la política autonómica, también sería equivocado creer que el autogobierno de los municipios y de las comunidades autónomas significa que en ese ámbito no deba operar el control parlamentario en las Cortes Generales. Nuestro Estado autonómico no está basado (ningún Estado compuesto hoy lo está) en la radical separación territorial de competencias, sino en la concurrencia de actuaciones y la compartición de tareas, es decir, en la cooperación funcional. Eso supone no sólo que la política territorial se realiza, conjuntamente, por el Esta- 
Este libro forma parte del acervo de la Biblioteca Jurídica Virtual del Instituto de Investigaciones Jurídicas de la UNAM

do y las entidades autónomas, sino que no puede haber política territorial eficaz sin un entendimiento general o nacional de la misma. Por ello, las Cortes Generales deben fiscalizar, además de la política autonómica del gobierno, el funcionamiento general de la organización territorial del poder. Con ello no se invadirían competencias ni de las comunidades autónomas ni de las entidades locales, puesto que la fiscalización a que se alude no supone (ni podría suponer) un control directo de los gobernantes territoriales, sino un control (ineludible) de la política general (es decir, de la política nacional) en materia autonómica.

Bien es cierto que el control parlamentario estatal respecto de la política autonómica acrecentaría sus posibilidades en cuanto hubiera una cámara en la que estén integradas las propias comunidades territoriales. De ahí la necesidad de reformar el Senado. Sin embargo, las actuales carencias de nuestra segunda cámara no son excusa suficiente para el escaso protagonismo que, hasta ahora, ha venido teniendo el Parlamento en lo que se refiere a las grandes decisiones de la política territorial, cuyo debate y adopción, en la mayor parte de las ocasiones, se ha producido al margen de las cámaras.

En cuanto a las carencias de fiscalización parlamentaria de las actividades de la amplia gama de personificaciones instrumentales (la mayoría bajo formas de derecho privado) que hoy se utilizan por el Estado, tanto para atender servicios públicos como para realizar actividades económicas o sociales de variada índole, ya sea mediante "agencias", "fundaciones públicas", "entidades gestoras" o "sociedades públicas", el problema también reside, probablemente, no tanto en la ausencia de instrumentos cuanto en el no uso de los que se tienen.

Es cierto, pueden afinarse mejor los actuales instrumentos de información y control previstos en los reglamentos de las cámaras para adecuarlos a las complejidades que presenta esta nueva realidad de actuación de lo "público" a través de formas características de lo "privado" o mediante complicadas (y a veces sorprendentes) formas administrativas casi enteramente desligadas de la 
Este libro forma parte del acervo de la Biblioteca Jurídica Virtual del Instituto de Investigaciones Jurídicas de la UNAM

relación de jerarquía que, como principio de actuación de las Administraciones públicas (en el sentido más amplio), la Constitución impone. Pero también es cierto que ello, siendo quizá muy conveniente, no es estrictamente necesario, pues la interpretación "constitucionalmente adecuada" de los actuales reglamentos de las cámaras ofrece asidero suficiente para sostener la pertinencia de la información y el control sobre el sector a que nos estamos refiriendo. Tanto del principio constitucional que proclama la responsabilidad de los poderes públicos (artículo 9.3 de la $\mathrm{CE}$ ) como de determinadas reglas constitucionales que establecen las posiciones básicas del gobierno y las Cortes en nuestro sistema parlamentario (artículos 66.2, 108, 109, 110.1 y 111.1 de la CE, entre otros), se desprende el derecho de las cámaras a conocer y la correspondiente obligación del Ejecutivo de informarles de todos los asuntos relativos a la función de gobierno en el sentido más amplio de la palabra (esto es, comprensivo de la totalidad de competencias que ese órgano atribuye el artículo 97 de la $\mathrm{CE}$ ).

El derecho de las cámaras (lo que equivale a decir, de los parlamentarios) a obtener información, por medio del gobierno, de las actividades de estos entes instrumentales, no puede ser negado bajo el pretexto de la autonomía de que gozan dichas entidades o de la "privacidad" que caracterice a sus actuaciones o estructuras empresariales. Aunque sobre tales entidades el gobierno no tenga, en sentido jurídico estricto, la "dirección”, como sí la tiene sobre la administración, no puede negarse que respecto de ellas el gobierno tiene, desde luego, la "responsabilidad". Responsabilidad (derivada no de la dirección jurídica, pero sí de la "dirección política" a la que también alude el artículo 97 de la CE) que dota de relieve "público" a esas entidades (por muy "privada" o "autónoma" que sea su formalización aparente o instrumental) y que obliga al gobierno, en consecuencia, a informar de ellas a las cámaras y a someterse en esa materia al control parlamentario. De otra parte, en cuanto que se emplee dinero público en el sostenimiento de esas entidades, no cabe negar, en modo alguno (y no se trata de una razón única, sino adicional a la anterior), el derecho 
Este libro forma parte del acervo de la Biblioteca Jurídica Virtual del Instituto de Investigaciones Jurídicas de la UNAM

de las cámaras a recibir información sobre sus actividades (y su organización), la obligación del gobierno de suministrarla y, por lo mismo, la pertinencia del control parlamentario en la materia.

\section{Control parlamentario y democracia de partidos}

De todos modos, los problemas de nuestro parlamentarismo no residen sólo en defectos atribuibles a la estructura y funcionamiento de las cámaras, a los que se ha venido aludiendo, sino, sobre todo, en algo más profundo: en los defectos del llamado "Estado de partidos". La importante función de los partidos está reconocida en la propia Constitución. Allí se dice (artículo 6o.) que los partidos políticos "expresan el pluralismo político, concurren a la formación y manifestación de la voluntad popular y son instrumento fundamental para la participación política". La democracia de nuestro tiempo es una democracia de partidos y difícilmente podría ser de otra manera. Sin la libertad de asociación política, esto es, sin la existencia de los partidos, no puede haber democracia auténtica, o lo que es igual, democracia pluralista. Sin unos partidos estables; es decir, socialmente arraigados y con el grado suficiente de cohesión o disciplina interna, no cabe esperar que la democracia sea una forma de organización política eficaz.

Ahora bien, la democracia de partidos no debe sustituir enteramente a la democracia de ciudadanos, puesto que si así ocurriese se estaría pervirtiendo la propia democracia, en la que, como su nombre indica, es el pueblo la única fuente del poder. Los partidos cumplen una función auxiliar: son instrumentos, valiosos, por supuesto, pero sólo instrumentos de la democracia; ésta no tiene por sujetos a los partidos sino a los ciudadanos. Más aún, tampoco los partidos agotan los cauces de expresión del pluralismo social, que se manifiesta también a través de los sindicatos, las asociaciones profesionales y las demás formaciones colectivas que integran la diversidad de creencias e intereses que existen en una comunidad de hombres libres. 
Este libro forma parte del acervo de la Biblioteca Jurídica Virtual del Instituto de Investigaciones Jurídicas de la UNAM

Quizá uno de los problemas políticos más serios del presente, en el nuestro y en otros países, consista en la tendencia de los partidos a introducirse en el seno de las organizaciones sociales, para influenciarlas o dirigirlas. Es el fenómeno de la tan denostada "politización" (mejor sería decir "partidización") de las empresas económicas, sociales o culturales. Al margen de las críticas frívolas, cuando no simplemente antidemocráticas, que ese fenómeno a veces recibe, el problema donde radica es en el deterioro de la espontaneidad social que ello conlleva, así como en las disfuncionalidades (o lisamente, ineficacias) que produce el traslado al ámbito de las organizaciones sociales de un tipo de racionalidad que allí resulta impropio. Poner los medios para que los partidos limiten sus actividades al mundo de las instituciones públicas, fomentándose (y no difuminándose) la distinción entre lo político y lo social, parece hoy una tarea urgente si quiere fortalecerse la democracia, que no puede soportar por mucho tiempo, sin grave riesgo, la confusión entre lo público y lo privado.

Por una parte, la misma, y propia, función de los partidos en las instituciones públicas, debe ser objeto de algunas reconsideraciones. De un lado, el importante papel que los partidos desempeñan (y que constitucionalmente tienen reconocido) exige al mismo tiempo que se extreme la obligación (también impuesta por la Constitución) de que su estructura interna y su funcionamiento sean democráticos, postulado muy fácil de enunciar, pero muy difícil de llevar a la práctica. Pese a las dificultades y a la casi irresistible tendencia oligárquica que se da en el seno de cualquier partido, la pretensión no es imposible y, probablemente, la salida de la crisis de legitimidad que hoy afecta a los partidos en buena parte de los países europeos, dependa, en no escasa medida, de la capacidad de éstos para dotarse de una razonable democracia interna. Por otro lado, el papel institucional de los partidos debe ser concebido en sus justos términos: de la misma manera que los partidos no pueden sustituir al pueblo, tampoco pueden sustituir al Estado. Por ello, la tan utilizada expresión "Estado de partidos" es, cuanto menos, incorrecta en un sistema democrático. 
Este libro forma parte del acervo de la Biblioteca Jurídica Virtual del Instituto de Investigaciones Jurídicas de la UNAM

Los partidos son, en nuestro ordenamiento, asociaciones privadas, aunque ese mismo ordenamiento reconozca, como es obvio, la relevancia pública de sus actividades. Ni los partidos son órganos del Estado ni pueden manifestar, por sí mismos, la voluntad estatal. La diferenciación entre el Estado y los partidos ni es una apariencia formalizada, es decir, una "ficción jurídica", ni es sólo un postulado del derecho impuesto por una lógica abstracta, sino una exigencia que proviene de la misma realidad política. Aceptar que la estructura orgánica estatal tiene un carácter ficticio, bajo el que se esconde, en realidad, la desnuda voluntad de los partidos, y pensar que esa situación puede ser duradera a condición de que no se haga demasiado patente que "el rey está desnudo", es no sólo una actitud cínica, sino, sobre todo, una actitud suicida. Una sociedad de hombres libres acaba, más tarde o más temprano, por dejar de obedecer los mandatos de la autoridad si ésta pierde su condición de representante de la voluntad de todos y si esos mandatos no están justificados por razones de interés general.

Ahora bien, que el Estado no deba ser el disfraz de los partidos no significa, ni mucho menos, que no haya de tenerse muy en cuenta la función de los partidos en la vida de las organizaciones públicas. Pero, claro está, de aquellas organizaciones públicas que respondan a la lógica partidista, esto es, a la lógica de las mayorías y las minorías producto de la representación. Esa lógica debe operar por ello, exclusivamente, en el ámbito parlamentario-gubernamental, puesto que es allí donde se manifiesta, legítimamente, el pluralismo político, sin que deba trasladarse a otras instituciones del Estado, especialmente las de naturaleza jurisdiccional, cuya composición y funciones descansan únicamente en razones de independencia y profesionalidad.

Es curioso, y perturbador, que allí donde tiene toda su legitimidad la actuación de los partidos, que es en la vida parlamentaria, sea donde resulta más débil su papel en nuestra práctica actual. De ahí que cualquier intento serio de fortalecer el parlamentarismo deba incluir, necesariamente, medidas que 
Este libro forma parte del acervo de la Biblioteca Jurídica Virtual del Instituto de Investigaciones Jurídicas de la UNAM

tiendan a reforzar la importancia parlamentaria de los partidos. No hay que dejarse engañar por las apariencias: nuestros partidos son muy eficaces para disciplinar la actividad parlamentaria, pero muy ineficaces para hacer de esa actividad el centro de interés de la política nacional (ahora los sindicatos, las organizaciones empresariales y la prensa ejercen mayor protagonismo político que las cámaras).

Unos partidos con muy bajo nivel de afiliación, financiados casi enteramente con dinero público y férreamente dominados por sus dirigentes, generan una clase política no ya burocratizada, sino, por así decirlo, "funcionarizada". En esas condiciones el Parlamento puede resultar muy bien organizado, eso sí, pero también quedar muy aislado de la sociedad. Con ese tipo de partidos se refuerza en las cámaras la previsibilidad en el decidir, pero se debilita enormemente la capacidad de discutir, que es, al fin y al cabo, la principal función parlamentaria. Por ello, vigorizar el papel de nuestras Cortes Generales no es algo que pueda conseguirse sólo modificando los reglamentos parlamentarios, exige además, y sobre todo, modificar el sistema electoral y las normas reguladoras del funcionamiento y financiación de los partidos. Es probable que también exija, pero ello es mucho más difícil de obtener, un cambio en nuestra cultura política que, todavía, por acción y por reacción, quizá está demasiado lastrada por los cuarenta años de franquismo.

Un buen camino para ir transformando esa cultura política haciéndola cada vez más democrática transcurre, indudablemente, por la ejemplaridad institucional; esto es, por la adopción y cumplimiento de unas pautas de conducta (de unas reglas políticas y no necesariamente de unas reglas jurídicas) en los órganos públicos, que los haga merecedores del reconocimiento de los ciudadanos. Ni qué decir tiene que el lugar principal para ejercer esa función ejemplarizadora está en el Parlamento. Fomentar en las cámaras su más genuina función, que es la discusión pública de los asuntos públicos, agilizando los debates, tratando los problemas importantes con la urgencia que requieren, dotán- 
Este libro forma parte del acervo de la Biblioteca Jurídica Virtual del Instituto de Investigaciones Jurídicas de la UNAM

dolas, en fin, de la "centralidad" política que exige la posición que en nuestro sistema constitucional ocupan, es, sin duda alguna, un buen modo de suscitar la confianza de los ciudadanos en su Parlamento. En ese marco se pone de relieve, justamente, la importancia de los instrumentos de información parlamentaria. De ahí que este capítulo haya querido situarse en una perspectiva tan general. La existencia de un vigoroso control parlamentario, además de contribuir a la racionalización de las actuaciones públicas contribuye, decididamente, a acrecentar la legitimidad popular del poder y, en ese sentido, a acortar la excesiva distancia que hoy separa a los representantes de sus representados. Ahora bien, sólo puede haber control parlamentario eficaz si hay plenitud de información. Por ello, cuando se plantean los problemas de la información en las cámaras se está planteando también, inexorablemente, un problema mucho más profundo: la misma razón de ser del Parlamento. 
Este libro forma parte del acervo de la Biblioteca Jurídica Virtual del Instituto de Investigaciones Jurídicas de la UNAM

Estudios sobre el Parlamento, editado por el Instituto de Investigaciones Jurídicas de la UNAM, se terminó de imprimir el 22 de septiembre de 2017 en los talleres de Gráfica Premier, S. A. de C. V., 5 de febrero 2309, colonia San Jerónimo Chicahualco, Metepec, 52170 Estado de México, tel. 01722199 1345. Se utilizó tipo Baskerville en 9, 10 y 11 puntos. En esta edición se empleó papel cream book de 60 gramos para los interiores y cartulina couché de 250 gramos para los forros; consta de 1000 ejemplares (impresión offset). 


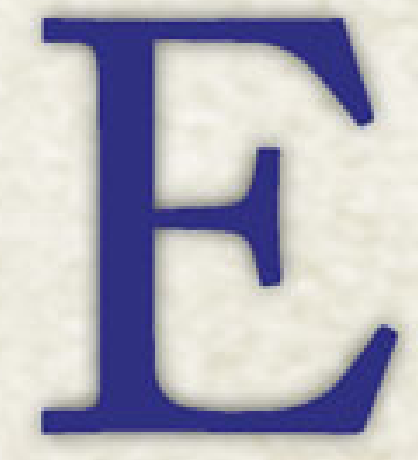

sta obra reúne una selección de los trabajos más representativos del autor sobre el Parlamento y los principales problemas que enfrenta actualmente. $\mathrm{El}$ autor puso especial énfasis en la ordenación jurídica del Parlamento; las funciones que lo caracterizan, en especial la legislativa y la de control; el significado que debe atribuirse al control parlamentario; la necesaria revalorización de la democracia representativa; las características de la forma parlamentaria de gobierno y otras grandes cuestiones acerca del papel crucial que el parlamento desempeña en los sistemas constitucionales democráticos. El punto de conexión dentro del conjunto de reflexiones que el libro contiene es la necesidad de vigorizar la institución parlamentaria como única vía para consolidar la democracia representativa frente a los retos que hoy se le presentan y, al mismo tiempo, la defensa de ésta como única forma para consolidar la democracia constitucional; sostiene además, que la democracia representativa puede ser complementada, pero de ninguna manera sustituida, por algunos instrumentos de democracia directa.

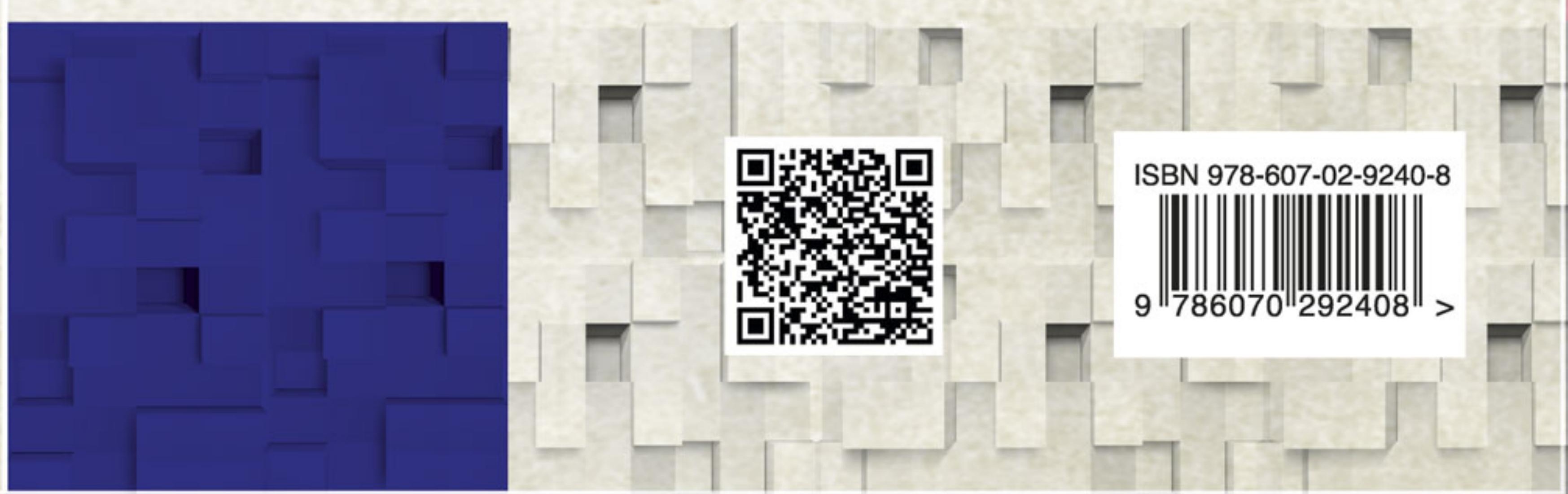

